Flávia Gonçalves de Oliveira Maestrali

\title{
Composição e diversidade do microbioma bacteriano do meato médio e do escarro de pacientes adultos com fibrose cística
}

\footnotetext{
Versão Corrigida

(Resolução CoPGr 6018/11 de 01 de novembro de 2011. A versão original está disponível na Biblioteca da FMUSP)
}

São Paulo

2019 
Flávia Gonçalves de Oliveira Maestrali

\title{
Composição e diversidade do microbioma bacteriano do meato médio e do escarro de pacientes adultos com fibrose cística
}

\author{
Tese apresentada à Faculdade de Medicina da \\ Universidade de São Paulo para obtenção do título \\ de Doutor em Ciências. \\ Programa de Otorrinolaringologia \\ Orientador: Prof. Dr. Richard Louis Voegels
}

Versão Corrigida

(Resolução CoPGr 6018/11 de 01 de novembro de 2011. A versão original está disponível na Biblioteca da FMUSP)

\section{São Paulo}




\section{Dados Internacionais de Catalogaçăo na Publicação (CIP)}

Preparada pela Biblioteca da

Faculdade de Medicina da Universidade de São Paulo

Creproduçāo autorizada pelo autor

Maestrali, Flávia Gonçalves de Oliveira

Composiçăo e diversidade do microbiona bacteriano

do meato médio e do escarro de pacientes adultos

con fibrose cística / Flávia Gonçalves de Oliveira

Maestrali. -- São Paulo, 2019.

Tese (doutorado)--Faculdade de Medicina da

Universidade de São Paulo.

Programa de Otorrinolaringologia.

Orientador: Richard Louis Voegels.

Descritores: 1.Fibrose cistica 2.Sinusite

3.Microbiologia 4. RNA ribossônico 16S

5. Sequenciamento de nucleotideos em larga escala

6. Anâlise de sequência de DNA 7.Volume expiratório

forçado 8.Seio etmoidal 9.Escarro

USP/EM/DBD-027/19

Responsável: Erinalva da Conceiçāo Batista, CRB-8 6755 
Dedico

A Deus, que me deu o dom da vida e sempre colocou pessoas maravilhosas no meu caminho, verdadeiros anjos que cuidam de mim.

Aos meus pais, Alexandre e Tercília, por todo amor e por nunca medirem esforços para auxiliar minha formação acadêmica, sempre me incentivando e inspirando.

Ao meu amado marido, José Neto, pelo amor e dedicação, e ao nosso filho, Tiago, que está para chegar e já enche nossas vidas de amor e alegria. 


\section{AGRADECIMENTOS}

Ao meu orientador, Prof. Dr. Richard Louis Voegels, que desde a época do meu Fellow me acolheu no grupo da Rinologia do Hospital das Clínicas e tanto me ensinou e inspirou.

Ao Prof Dr. Ricardo Ferreira Bento, Professor Titular do Departamento de Otorrinolaringologia da FMUSP, pelo exemplo de serviço de excelência e de inovação para Otorrinolaringologia.

À Profa. Dra. Carla Taddei, professora do departamento de Análises Clinicas e Toxicológicas, da Faculdade de Ciências Farmacêuticas da USP, por toda ajuda e dedicação, fundamentais para a concretização deste projeto.

À Dra. Renata Pilan, pelo apoio e entusiasmo desde as primeiras fases deste estudo, e, sobretudo pela amizade.

Aos membros da minha banca de qualificação, Prof. Dr. Luiz Ubirajara Sennes, Dr. Rui Imamura e Dra. Renata Pilan, pelas críticas e sugestões que foram de grande valia para a finalização deste projeto.

À Dra. Tatiana Abdo, por compartilhar seus conhecimentos, pela convivência quase diária durante o Fellow, que o deixou muito mais leve e agradável, e pela amizade que ficou.

Ao Dr. Fábio Pinna, Dr. Thiago Bezerra, Dr. Marco Fornazieri pela ajuda e sugestões no início deste projeto.

Ao Dr. Rodrigo Athanazio, Dra. Samia Rached, pneumologistas do Hospital das Clínicas e Dra Silvia Vidal Campos, infectologista do InCor pelo exemplo de cuidado e carinho com os pacientes com fibrose cística e por toda ajuda na logística e andamento na fase de coleta das amostras.

Aos otorrinolaringologistas assistentes do Hospital Santa Marcelina, Dr. Oswaldo Martucci, Dr. José Alexandre Medicis, Dr. Silvio Marone, Dra. Fabiana D'Ottaviano, Dra. Renata Lopes Mori, Dr. Elder Goto, Dra. Letícia Clemente, Dr. 
Márcio Souza, Dr. Christian Wiikmann, Dr. José Luiz Rodrigues, Dr. Raphael Gomes, Dr. Rogério Faidiga, Dr. Ali Mahmoud, que tiveram papel fundamental na minha formação como otorrinolaringologista e tanto me ensinaram durante a residência médica.

Aos colegas que me acompanharam durante a Residência e Fellow, pelo companheirismo e amizade, Rachel, Renato, Tarcísio, Guilherme, Ricardo, Francine, Alice, Leonardo, Marco Antônio, Nelson, Diego, Daniela, Aline, Deusdedit, Diogo, Rafael e Carol.

Ao Prof. Dr. Márcio Nakanishi, pelo apoio, incentivo desde a minha ida à São Paulo para residência médica até as oportunidades oferecidas no meu retorno a Brasília.

Aos alunos da pós-graduação, Gustavo Sparvoli e Ramon Cortez, pelo auxílio fundamental nas análises de bioinformática.

À Profa. Dra. Barbara Rzyski, pelo trabalho de revisão gramatical e ortográfica, e formatação de minha tese, realizados com tanto cuidado e capricho.

À Marilede, Luci, Márcia, Kátia e Cris por toda ajuda, pelo carinho e atenção.

À minha família, meus pais Alexandre e Tercília, meus irmãos Bruno e Luísa, minha cunhada Renata, meus sogros Fernando e Milza, meus cunhados Maria Fernanda e Eder, meus sobrinhos, Pedro, João, Lara e Ana, e principalmente ao meu marido amado José Neto e nosso pequeno Tiago, que compreenderam meus momentos de estresse e minhas inúmeras viagens a São Paulo. O amor, o apoio e o incentivo de vocês me fizeram chegar até aqui.

Aos pacientes que participaram desse estudo, com boa vontade e disposição em ajudar no progresso das pesquisas. A vocês minha admiração pela resiliência e força de vontade.

E, a todos que contribuíram de alguma forma para a realização deste sonho. 


\section{AGRADECIMENTOS ESPECIAIS}

À Coordenação de Aperfeiçoamento de Pessoal de Nível Superior (Capes) pela concessão da bolsa de doutorado.

À Fundação de Amparo à Pesquisa do Estado de São Paulo (FAPESP), pela concessão de auxílio à pesquisa e apoio financeiro para a realização deste projeto. 


\section{SUMÁRIO}

Lista de abreviaturas

Lista de siglas

Lista de símbolos

Lista de figuras

Lista de tabelas

Resumo

Abstract

1 INTRODUÇÃO

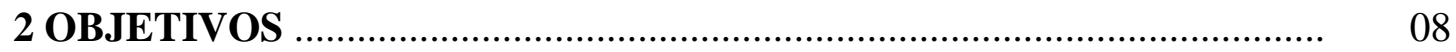

2.1 Objetivo principal n................................................................................... 09

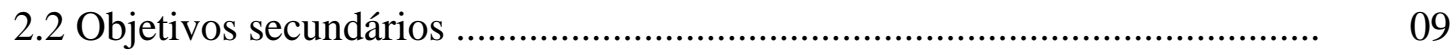

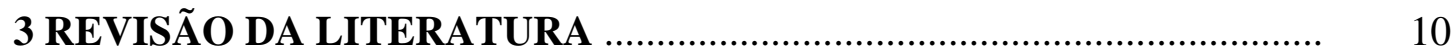

3.1 Microbioma nasossinusal em adultos saudáveis ......................................... 11

3.2 Microbiologia na rinossinusite crônica ...................................................... 12

3.3 Microbioma na fibrose cística .................................................................. 14

4 PACIENTES E MÉTODOS ….......................................................... 19

4.1 Coleta de amostras .................................................................................... 21

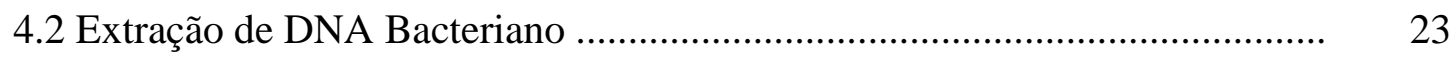

4.3 Sequenciamento de Nova Geração ............................................................ 23

4.4 Amplificação de sequências-alvo ............................................................... 24

4.5 Purificação dos produtos da PCR …………................................................ 24

4.6 Reação de PCR para anexo dos adaptadores ................................................ 25

4.7 Purificação da biblioteca final .................................................................... 25

4.8 Preparo do pool equimolar das bibliotecas amplificadas ............................ $\quad 26$

4.9 Processamento das sequencias obtidas por bioinformática ......................... 26

4.10 Análise dos resultados ....................................................................... 27

4.11 Análise estatística ............................................................................... 28

4.11.1 Análise estatística das características demográficas e clínicas dos

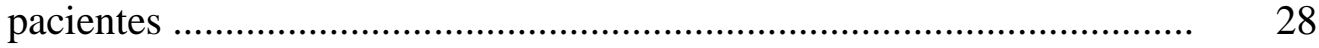

4.11.2 Análise estatística do microbioma ........................................................ 28 
5.1 Caracterização do Grupo amostral .......................................................... 30

5.2 Caracterização do Microbioma ............................................................... 31

5.2.1 Abundância Relativa - Filos e Gêneros bacterianos ................................ 31

5.2.1.1 Por tipo de amostra .......................................................................... 31

5.2.1.2 Por função pulmonar (gravidade da doença pulmonar) ........................ 35

5.2.2 Análise das diversidades (alfa e beta diversidade) ................................... 44

5.2.2.1 Alfa diversidade - Índices de Shannon, Simpson e Chao 1 ................... 44

5.2.2.2 Beta diversidade - ponderada (Weighted) e não ponderada (Underweighted $)$............................................................................. 46

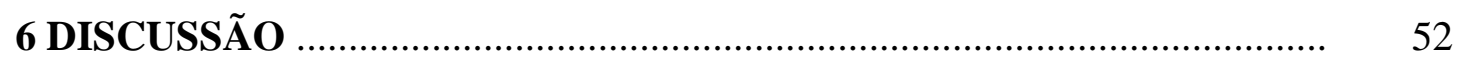

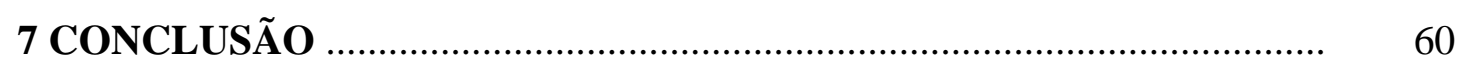

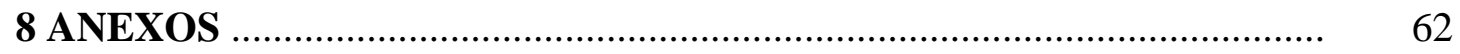

Anexo A - NOSE ....................................................................................... 63

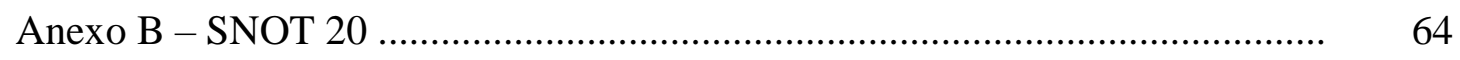

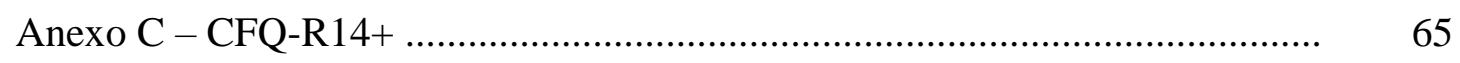

Anexo D - Pontuação da avaliação endoscópica de Lund-Kennedy .................. 71

9 REFERÊNCIAS BIBLIOGRÁFICAS ..................................................... 72 APÊNDICES

Apêndice 1 - Aprovação pelo Comitê de Ética

Apêndice 2 - Termo de Consentimento Livre e Esclarecido 


\section{LISTA DE ABREVIATURAS}

16S rRNA Componente 16S do Ácido Ribonucleico ribossomal

CFQ-R14+ Cystic Fibrosis Questionnaire Revised (Questionário de Qualidade de Vida em Fibrose Cística Revisado para maiores de 14 anos)

DNA Ácido Desoxirribonucleico

DP Desvio-padrão

F Teste F

FC Fibrose Cística

MRSA Methicillin-resistant Staphylococcus aureus (Staphylococcus aureus resistente a meticilina)

n quantidade

NOSE Nasal Obstruction Symptom Evaluation (Avaliação dos Sintomas Nasais Obstrutivos)

OTU Operational Taxonimic Unit (Unidade Taxonômica Operacional)

p valor-p

PCoA Principal Coordinates Analysis (Análise das Principias Coordenadas)

PCR Polymerase Chain Reaction (Reação em Cadeia da Polimerase)

pH Potencial hidrogeniônico

QIIME Quantitative Insights Into Microbial Ecology

RNA Ácido Ribonucleico

RSC Rinossinusite crônica

SNOT-20 20-Item Sino-Nasal Outcome Test (Teste de desfechos nasossinusais com 20 itens)

VEF1 Volume Expiratório Forçado no primeiro segundo 


\section{LISTA DE SIGLAS}

CAPPesq Comissão de Ética para Análise de Projetos de Pesquisa

FAPESP Fundação de Amparo à Pesquisa do Estado de São Paulo

HCFMUSP Hospital das Clínicas da Faculdade de Medicina da Universidade de São Paulo

NIH

National Institutes of Health 


\section{LISTA DE SÍMBOLOS}

$\begin{array}{ll}{ }^{\mathbf{C}} & \text { grau Celsius } \\ \mathbf{m i n} & \text { minuto } \\ \mathbf{m L} & \text { mililitro } \\ \mathbf{m M} & \text { milimol } \\ \mathbf{n g} & \text { nanograma } \\ \mathbf{n M} & \text { nanomol } \\ \mathbf{p M} & \text { picomol } \\ \mathbf{S} & \text { segundo } \\ \boldsymbol{\mu L} & \text { microlitro } \\ \boldsymbol{\mu M} & \text { micromol } \\ \sim & \text { aproximadamente } \\ \mathbf{=} & \text { igual } \\ > & \text { maior } \\ \geq & \text { maior ou igual } \\ < & \text { menor } \\ \leq & \text { menor ou igual } \\ \mathbf{\%} & \text { por cento }\end{array}$




\section{LISTA DE FIGURAS}

Figura 1 Principais filos encontrados nas amostras de meato médio e escarro em cada paciente

Figura 2 Principais gêneros bacterianos encontrados nas amostras de meato médio e escarro em cada paciente

Figura 3 Média dos principais gêneros bacterianos encontrados por sítio de coleta

Figura 4 Gêneros bacterianos nas amostras de meato médio de acordo com a gravidade da doença pulmonar

Figura 5 Principais gêneros bacterianos encontrados nas amostras de meato médio de acordo com a gravidade da doença pulmonar em cada paciente

Figura 6 Filos bacterianos nas amostras de escarro de acordo com a gravidade da doença pulmonar

Figura 7 Gêneros bacterianos nas amostras de escarro de acordo com a gravidade da doença pulmonar

Figura 8 Principais gêneros bacterianos encontrados nas amostras de escarro de acordo com a gravidade da doença pulmonar em cada paciente

Figura 9 Principais gêneros bacterianos observados nas amostras de meato médio e escarro dos pacientes com função pulmonar discreta a moderada e grave. (\#número de identificação de cada paciente; MM: Amostras de meato médio; $\mathrm{S}$ : amostras de escarro)

Figura 10 Alfa Diversidade nas amostras de meato médio de acordo com a gravidade da doença pulmonar (azul: discreta/moderada; verde: grave): a) índices de Chao1, b) Simpson e c) Shannon

Figura 11 Alfa diversidade nas amostras de escarro de acordo com a gravidade da doença pulmonar (azul: discreta a moderada; verde: grave): a) índices de Chao1, b) Simpson e c) Shannon 
Figura 12 Análise de coordenadas principais (PCoA) entre os tipos de amostra - ponderada (esquerda) e não ponderada (direita): a) por sítio de coleta; b) por gravidade da doença; c) uso ou não de dornase alfa; d) uso ou não de antibiótico inalatório e e) uso ou não de antibiótico oral profilático

Figura 13 Análise de coordenadas principais (PCoA) das amostras de meato médio - ponderada (esquerda) e não ponderada (direita): a) gravidade da doença; b) uso de dornase alfa; c) uso de antibiótico inalatório e d) uso de antibiótico oral profilático

Figura 14 Análise de coordenadas principais (PCoA) das amostras de escarro - ponderada (esquerda) e não ponderada (direita): a) gravidade da doença; b) uso de dornase alfa; c) uso de antibiótico inalatório e d) uso de antibiótico oral profilático 


\section{LISTA DE TABELAS}

Tabela 1 Características demográficas e clínicas dos pacientes dos dois grupos com diferentes estágios da doença

Tabela 2 Abundância relativa dos principais filos nas amostras de meato médio e escarro

Tabela 3 Abundância relativa dos principais gêneros nas amostras de meato médio e escarro

Tabela 4 Abundância relativa dos principais filos nas amostras de meato médio de acordo com a gravidade da doença pulmonar

Tabela 5 Abundância relativa dos principais gêneros nas amostras de meato médio de acordo com a gravidade da doença pulmonar

Tabela 6 Abundância relativa dos principais filos nas amostras de escarro de acordo com a gravidade da doença pulmonar

Tabela 7 Abundância relativa dos principais gêneros nas amostras de escarro de acordo com a gravidade da doença pulmonar ....

Tabela 8 Alfa diversidade de acordo com a gravidade da doença pulmonar nas amostras de meato médio

Tabela 9 Alfa diversidade de acordo com a gravidade da doença pulmonar nas amostras de escarro 


\section{RESUMO}

Maestrali FGO. Composição e diversidade do microbioma bacteriano do meato médio e do escarro de pacientes adultos com fibrose cística [tese]. São Paulo: Faculdade de Medicina, Universidade de São Paulo; 2019.

INTRODUÇÃO: A principal causa de mortalidade em pacientes com fibrose cística é o declínio da função pulmonar, relacionada à infecção respiratória de repetição. A rinossinusite crônica pode contribuir na deterioração da função pulmonar, porque o nariz e seios paranasais podem representar um reservatório de potenciais patógenos que causam as infecções pulmonares recorrentes ou crônicas. Métodos como o sequenciamento de nova geração, na identificação do microbioma, mostraram a natureza polimicrobiana das infecções respiratórias em fibrose cística, com a caracterização de agentes infecciosos não detectados nos métodos convencionais de cultura. Ainda muito pouco se sabe a respeito da composição e diversidade do microbioma desses pacientes. OBJETIVO: Descrever a composição do microbioma bacteriano do meato médio e do escarro de pacientes adultos com fibrose cística. Comparar riqueza, diversidade e dominância do microbioma dos pacientes com doença pulmonar discreta ou moderada com pacientes com doença pulmonar grave. PACIENTES E MÉTODOS: Foi avaliado o microbioma do meato médio e escarro de 31 adultos com fibrose cística, utilizado a análise do gene 16S rRNA por meio do sequenciamento de nova geração. RESULTADOS: Staphylococcus, Streptococcus e Corynebacterium foram os gêneros mais abundantes no meato médio e Pseudomonas, Haemophilus e Prevotella, no escarro. Nos pacientes com doença grave, observamos um aumento na prevalência de Pseudomonas nos dois sítios estudados isoladamente. $\mathrm{Na}$ análise pareada de escarro e meato médio, obtivemos concordância na composição do microbioma apenas em pacientes com doença discreta a moderada, o mesmo não foi observado no grupo com doença grave. CONCLUSÃO: O avanço nos conhecimentos da composição e diversidade do microbioma nas vias aéreas dos pacientes com fibrose cística é fundamental para o entendimento da fisiopatologia da doença, além de seu papel na criação novas perspectivas e possibilidades de tratamentos. Esse é o primeiro trabalho brasileiro a estudar o microbioma de vias aéreas em pacientes com fibrose cística. Nossos achados estão em concordância com a literatura internacional, ao apontar a Pseudomonas como importante elemento na fisiopatologia da doença, presente tanto no escarro como no meato médio dos pacientes com doença pulmonar grave.

DESCRITORES: Fibrose Cística; Sinusite; Microbiologia; RNA Ribossômico 16S; Sequenciamento de nucleotídeos em larga escala; Análise de Sequência de DNA; Volume expiratório forçado; Seio etmoidal; Escarro. 


\begin{abstract}
Maestrali FGO. Composition and diversity of the middle nasal meatus and sputum microbiome in cystic fibrosis adults [thesis]. São Paulo: "Faculdade de Medicina, Universidade de São Paulo"; 2019.

INTRODUCTION: The main cause of mortality in patients with cystic fibrosis is the decline in lung function, related to recurrent respiratory infection. Chronic rhinosinusitis leads to significant morbidity and contributes to the pathophysiology of lung disease. In cystic fibrosis, the nose and paranasal sinuses may represent a reservoir of potential respiratory pathogens and contribute to recurrent or chronic lung infections. Culture independent molecular detection methods of microbiome have shown the polymicrobial nature of respiratory infections in cystic fibrosis, with the characterization of undetectable pathogenic agents in conventional culture methods. Composition and diversity of the airway microbiome is still poor explored. METHODS: This study evaluated the airway microbiome of 31 adult cystic fibrosis patients, with the analysis of the $16 \mathrm{~S} r R N A$ by the next generation sequencing. RESULTS: Staphylococcus, Streptococcus e Corynebacterium were the most abundant genera in middle meatus and Pseudomonas, Haemophilus e Prevotella, in sputum. In patients with advanced disease, we noticed an increase in Pseudomonas prevalence in both sample types studied separately. In paired analysis, sputum and middle meatus have shown a similarity in microbiome composition in patients with mild or moderate disease. This was not observed in patients with advanced disease. CONCLUSION: Advances in the knowledge of the composition and diversity of the airway microbiome of cystic fibrosis patients are essential for understanding the pathophysiology of the disease. It has an important role in creating new perspectives and possibilities of treatments. There is a lack in the literature of studies with evaluation of the airway microbiome of these patients in Brazil. This is the first Brazilian study to evaluate the airway microbiome of cystic fibrosis patients. Our finds agreed with international literature, when point at Pseudomonas role in disease pathophysiology, present in sputum and middle meatus of patients with advanced disease.
\end{abstract}

DESCRIPTORS: Cystic Fibrosis; Sinusitis; Microbiology; RNA, Ribosomal, 16S; High-Throughput Nucleotide Sequencing; Sequence Analysis, DNA, Forced Expiratory Volume; Ethmoid Sinus; Sputum. 
1 INTRODUÇÃ̃O 


\section{INTRODUÇÃO}

A fibrose cística (FC) é uma doença autossômica recessiva que se caracteriza por uma disfunção de vários órgãos e sistemas. O defeito genético é localizado no braço longo do cromossomo 7, no gene regulador da condutância transmembrana, o que provoca a alteração no transporte do íon cloro através da superfície de células epiteliais. Dessa forma, a superfície mucosa das vias aéreas superiores e inferiores sofre grandes modificações, com aumento da viscosidade do muco e redução do transporte mucociliar $^{(1,2)}$, predispondo à inflamação e infecção crônicas por Staphylococcus aureus e Pseudomonas aeruginosa.$^{(3)}$ É caracterizada clinicamente por aumento na concentração de sal no suor, mal absorção, diabetes, azoospermia, rinossinusite crônica, infecções pulmonares recorrentes. ${ }^{(4)}$

A FC é considerada a doença autossômica recessiva mais letal entre os caucasianos. Estima-se que sua prevalência seja de um em 2.000 a 6.000 nascidos vivos. ${ }^{(5)}$ Em 1950, a expectativa de vida de pacientes com FC era de alguns meses ${ }^{(2)}$. Em 1974, os acometidos morriam, em média, aos 8 anos de idade. $\mathrm{O}$ avanço dos estudos, o tratamento multidisciplinar e o uso de antibióticos aumentaram significativamente a média de sobrevida desses pacientes, que atualmente é estimada em 40 anos. ${ }^{(6)}$ A causa principal de mortalidade em pacientes com FC é o declínio da função pulmonar, relacionada com infecções respiratórias de repetição. ${ }^{(7-9)} \mathrm{O}$ acometimento sinusal não está diretamente relacionado à mortalidade da doença, entretanto, a rinossinusite crônica leva a uma morbidade importante, além de contribuir com a fisiopatologia da doença pulmonar. ${ }^{(5)}$

Em 2016, segundo o relatório do Registro Brasileiro de Fibrose Cística 2016, foram acompanhados 3.212 pacientes com fibrose cística nos diversos centros médicos no Brasil, e 27,3\% desses atendidos eram do Estado de São Paulo. Naquele ano, foram acompanhados 108 pacientes adultos no Hospital das Clínicas (HC) da Faculdade de Medicina da Universidade de São Paulo (FMUSP). ${ }^{(10)}$

A doença pulmonar pode ser classificada de acordo com a porcentagem prevista do Volume Expiratório Forçado no primeiro segundo (VEF1) em: discreta ( $\geq 70 \%)$; 
moderada (40\% a 69\%); e, grave ( $<40 \%)$. O VEF1 é comumente utilizado para mensurar a função pulmonar e representa o melhor preditor de sobrevida para pacientes com FC. ${ }^{(11,12)}$

A via aérea humana pode ser dividia em compartimentos com ambientes e características distintos, assim distribuídos: o nariz e os seios paranasais; a zona condutiva, composta por traqueia e brônquios; e, a zona respiratória composta por bronquíolos e alvéolos. O nariz e os seios paranasais são o primeiro compartimento da via aérea e apresentam íntima relação com o ambiente externo. $\mathrm{Na} F C$, esse compartimento contém muco espesso que pode funcionar como substrato para o crescimento bacteriano. Além disso, as cavidades sinusais, quando comparadas às vias aéreas inferiores, têm menor fluxo aéreo e menor suscetibilidade aos antibióticos e à defesa do organismo. ${ }^{(6)}$ Dessa forma, os seios paranasais podem representar um reservatório de patógenos respiratórios potenciais ${ }^{(13)}$ e contribuir com as infecções pulmonares recorrentes ou crônicas. ${ }^{(6)}$

Pacientes portadores de FC submetidos a transplante pulmonar apresentam colonização por Pseudomonas com mutação e expressão gênica similares às encontradas antes do transplante. ${ }^{(14)}$ Pacientes com FC submetidos à cirurgia endoscópica endonasal seguida por antibioticoterapia endovenosa por 2 semanas e irrigação nasal com antibiótico tópico por 6 meses, obtiveram uma redução na ocorrência de culturas de vias aéreas inferiores (escarro, aspiração endolaríngea ou lavado broncoalveolar) positivas para patógenos relacionados com a FC, no primeiro ano após a cirurgia. ${ }^{(15)}$ Tais estudos indicam um indício forte de que os seios paranasais funcionam como reservatórios de microrganismos patogênicos.

Um dos principais desafios no tratamento de um paciente com fibrose cística é retardar a colonização permanente por Pseudomonas aeruginosa e esse tem sido prioritário no tratamento da FC em muitos centros pediátricos. ${ }^{(2)}$ Algumas cepas de $P$. aeruginosa, durante a colonização inicial, sofrem uma série de mutações, como a produção de alginato e formação de biofilme, que aumentam a resistência a antibióticos e favorecem a colonização crônica. ${ }^{(4)}$ Além disso, a colonização crônica do pulmão por essa bactéria está associada à inflamação crônica, com predomínio de polimorfonucleares, provocando dano tecidual e declínio da função pulmonar. Apesar dos esforços e terapia antimicrobiana intensa, a maioria dos pacientes passa por uma fase de 
colonização intermitente das vias aéreas até que, por volta da terceira década de vida, contrai a infecção crônica por $P$. aeruginosa. Durante a fase de colonização intermitente, cerca de $25 \%$ dos casos de recolonização ocorrem por uma bactéria com o mesmo genótipo, indicando um foco de contaminação ambiental persistente ou um reservatório não identificado no próprio paciente. E quando se compara bactérias, como S. aureus e P. aeruginosa, presentes no lavado nasal e no escarro dos pacientes com FC, há uma concordância elevada de genótipos, com evidência de infecção cruzada entre vias aéreas superiores e inferiores. ${ }^{(6)} \mathrm{Um}$ estudo mostra resultado semelhante, quando a cultura do aspirado sinusal é comparada com o lavado broncoalveolar. É observada uma associação significativa entre os microrganismos principais isolados nas vias aéreas superiores e inferiores, como P. aeruginosa e S. aureus. ${ }^{(4,16)}$ A Achromobacter xylosoxidans e a Burkholderia cepacia, embora menos prevalentes, têm papel semelhante ao da Pseudomonas no declínio da função pulmonar. ${ }^{(4)}$

Maliniak et al. ${ }^{(17)}$ mostraram que pacientes com FC que apresentavam infecção crônica concomitante por Staphylococcus aureus resistente à meticilina (MRSA) e Pseudomonas aeruginosa, tinham uma redução significativa da função pulmonar ao longo do tempo, quando comparados, isoladamente, a pacientes infectados por apenas uma dessas bactérias. O potencial patogênico de uma microbiota com uma mistura de diversas espécies pode ser diferente e até maior do que o de uma bactéria individualmente. A interação entre as espécies pode influenciar a virulência de uma bactéria em uma comunidade polimicrobiana. Portanto, ao avaliar o potencial patogênico de uma dada bactéria, deve-se considerar o contexto microbiano em que ela está inserida. ${ }^{(18)}$

Na prática clínica, a microbiologia das infecções de vias aéreas em pacientes com FC tem sido determinada por métodos de cultura, com foco nos microrganismos mais comumente isolados como Staphylococcus aureus, Pseudomonas aeruginosa e Haemophilus influenzae. Mais recentemente, métodos independentes de cultura, como o PCR e as técnicas de sequenciamento genético, mostraram a natureza polimicrobiana das infecções respiratórias em pacientes com FC, com a caracterização de agentes infecciosos não detectados pelos métodos convencionais. ${ }^{(13,19)}$ Estima-se que, a depender do sítio estudado, $20 \%$ a $70 \%$ das bactérias presentes não crescem em cultura, mesmo em condições ideais. ${ }^{(20,21)}$ Hauser et al. ${ }^{(22)}$ observaram que apenas $47,7 \%$ das bactérias com mais de $10 \%$ de abundância foram identificadas por métodos de cultura e, quando 
bactérias com abundância relativa baixa $(<1 \%)$ são levadas em consideração, apenas $4,5 \%$ são identificadas.

Estudos com sequenciamento genético com rendimento elevado e o surgimento de novos softwares estão revolucionando a análise em microbiologia. ${ }^{(23)}$ As plataformas de sequenciamento geram um volume considerável de dados acerca de sequências de genes biomarcadores, permitindo análises mais abrangentes da composição e abundância relativa de microrganismos em uma dada comunidade. Com base na recente expansão de dados de sequência de biomarcadores, pode-se traçar o perfil de milhares de organismos em um único ensaio paralelo. Ultimamente essas ferramentas estão sendo aplicadas a amostras respiratórias de pacientes com FC e muitas outras doenças, chamando a atenção para a complexidade das comunidades microbianas presentes nas vias aéreas de pacientes portadores de doenças inflamatórias crônicas. ${ }^{(24,25)}$

O Projeto Microbioma Humano do National Institutes of Health (NIH) surgiu após o argumento de Julian Davies, de que o projeto genoma humano, publicado em 2001, estaria incompleto até que se conhecesse as interações dos microrganismos presentes no corpo humano com as células humanas. Isso porque existem dez vezes mais células microbianas do que células humanas em nosso corpo. A variação desse microbioma nas diversas fases da vida do ser humano e nos sítios de colonização de seu corpo, além das variações relacionadas com a região geográfica em que vive e a cultura em que está inserido precisam ser amplamente exploradas. O objetivo final de tal projeto é o conhecimento profundo do microbioma em seus diversos sítios com suas variações intrínsecas destinado a criar oportunidades para melhorar o tratamento de doenças por meio da monitorização ou, até mesmo, a manipulação do microbioma. ${ }^{(20,26)}$

Após começar a catalogação dos microrganismos e abundância relativa associada à saúde e à cada doença, inicia-se uma nova fase que é a de estabelecer relações entre o microbioma, desfechos e prognóstico, para alcançar novas formas terapêuticas. $\mathrm{O}$ avanço tecnológico rápido também contribui para que isso, em breve, tenha aplicação na prática clínica com benefícios ao paciente. ${ }^{(18)}$

Novas tecnologias e novas ferramentas de bioinformática têm reduzido gradativamente os custos de sequenciamento, e permitem estabelecer relação entre centenas de amostras ao mesmo tempo. Uma das técnicas que permite avaliar a 
microbiota de um dado local, a metagenômica, fornece dados do sequenciamento de todo ácido desoxirribonucleico (DNA) presente na amostra. Outra possibilidade é o sequenciamento do componente $16 \mathrm{~S}$ do ácido ribonucleico (RNA) ribossomal (16S rRNA), que, com um volume menor de dados, permite estabelecer a composição do microbioma por se tratar de um excelente marcador filogenético. O gene $16 S$ rRNA está presente em todas as bactérias e contém regiões altamente conservadas ao longo da evolução e nove regiões variáveis de uma espécie para outra (V1 - V9), permitindo a identificação e a classificação filogenética dos elementos presentes em uma dada amostra. ${ }^{(23,27,28)}$ A maioria dos estudos sobre microbioma tem foco no seu componente bacteriano ${ }^{(29)}$ e é a ele que esse termo se refere.

Por meio de análises de bioinformática é possível determinar a diversidade e a riqueza do microbioma, ou seja, a quantidade total e a abundância de espécies ou gêneros presentes em cada amostra. Essa riqueza e abundância são mensuradas por meio da diversidade alfa. É possível, ainda, analisar a diversidade beta que determina a diferença entre grupos de amostras, quanto à composição da comunidade microbiana. ${ }^{(27)}$

A ampliação do conhecimento sobre a composição e a diversidade do microbioma nasossinusal de pacientes com FC é importante para auxiliar o entendimento da fisiopatologia da doença, tendo em vista a compartimentalização da via aérea e provável papel dos seios paranasais como reservatório de bactérias que provoquem infecções pulmonares. Em um futuro próximo, talvez, seja possível manejar adequadamente os episódios recorrentes de rinossinusite apresentados por esses pacientes. Além disso, pode ser um caminho para a descoberta de meios de tratamento mais modernos, tão necessários, uma vez que, apesar do inegável benefício dos antibióticos em prolongar a expectativa de vida desses pacientes, a resistência bacteriana crescente e a carência de novas drogas forçam a pensar em alternativas para o tratamento dessa doença. Se o foco da bactéria patogênica for mudado para o contexto microbiano em que ela está inserida, talvez seja possível ampliar essas perspectivas.

Alguns estudos com nível de evidência II b mostram uma correlação razoável entre amostras coletadas do meato médio sob visualização endoscópica e amostras coletas diretamente do seio maxilar. ${ }^{(30)}$ Um estudo específico em que foi comparado o microbioma encontrado na biópsia e no swab do meato médio de pacientes com rinossinusite crônica, não foi observada diferença estatisticamente significativa quanto à 
riqueza e diversidade entre os dois métodos ${ }^{(31)}$, no entanto, o tamanho reduzido da amostra pode ter sido o motivo de não haver diferença.

O meato médio é local de drenagem dos seios maxilar, etmoide e frontal, portanto, pode ser considerado como representante da microbiota sinusal. $\mathrm{O}$ acesso ao meato médio, para coleta de material, ocorre de forma menos invasiva quando comparado com a coleta de material diretamente do seio maxilar, que, na prática clínica, facilita a reprodutibilidade do método. 
2 OBJETIVOS 


\section{OBJETIVOS}

\subsection{Objetivo principal}

- Descrever a composição do microbioma do meato médio e do escarro de pacientes adultos com fibrose cística.

\subsection{Objetivos secundários}

- Comparar a riqueza, a diversidade e dominância do microbioma de pacientes com doença pulmonar discreta/moderada - Volume Expiratório Forçado no Primeiro Segundo (VEF1) $\geq 50 \%$ - com pacientes que apresentam doença pulmonar grave - VEF1<40\%;

- Comparar a composição, a diversidade e a dominância do microbioma do meato médio com o microbioma do escarro em cada indivíduo. 
3 REVISÃO DA LITERATURA 


\section{REVISÃO DA LITERATURA}

\subsection{Microbioma nasossinusal em adultos saudáveis}

Os seios paranasais já foram, por algum tempo, considerados estéreis em indivíduos saudáveis, sem patologias nasossinusais. Hoje, sabe-se que abrigam uma comunidade de microrganismos diversos. Bactérias, inclusive as patogênicas, podem ser encontradas em pessoas hígidas desde que não seja dada, a esses microrganismos, a oportunidade de supercrescimento. ${ }^{(21)}$ No Projeto Microbioma Humano, na análise do swab das narinas de sujeitos saudáveis, foram encontradas algumas bactérias ditas oportunistas, como Staphylococcus epidermidis, S. aureus, Propoionibacterium acnes, Klebisiella pneumoniae, E. coli, Sterptococcus pneumoniae, dentre outros. Os P. acnes e S. epidermidis eram os mais abundantes. ${ }^{(29)}$

Ao avaliar o microbioma nasal, coletado por meio de swab nas narinas de sete pacientes saudáveis, Lemon et al. ${ }^{(32)}$ encontraram uma relação inversa elevada quanto a prevalência de bactérias do filo Firmicutes (que abrange patógenos importantes como os da família Staphylococcaceae) e do filo Actinobacteria (famílias Corynebacteriaceae e Propionibacteriaceae), com um Coeficiente de Correlação de Pearson $=-0,95, \mathrm{p}<0,001$, que sugeriu um antagonismo potencial entre esses grupos.

Em um estudo transversal, em que foram avaliados 28 pacientes saudáveis, por meio de $s w a b$ de meato médio, os filos Firmicutes, Proteobacteria e Actinobacteria foram encontrados em $100 \%$ dos indivíduos. As espécies mais prevalentes foram Staphylococcus epidermidis (96,4\%), Propionibacterium acnes (92,9\%) e Staphylococcus aureus (67,9\%). E foram as mais abundantes também, com abundância relativa de $11,0 \%, 14,7 \%$ e $8,3 \%$, respectivamente. ${ }^{(33)}$ Um outro estudo em que também foi avaliado o microbioma nasal por meio do $s w a b$ entre o septo e corneto médio, permitiu constatar que a cavidade nasal era dominada pelos filos Actinobacteria, Firmicutes e, em alguns casos, Proteobacteria. A mesma Unidade Taxonômica Operacional (do inglês Operational Taxonimic Unit - OTU) de Staphylococcaceae estava presente em 100\% das amostras nasais, com abundância relativa de $2,2 \%$ a 55\%. ${ }^{(34)}$ 
Em estudo no qual foram comparados sete pacientes portadores de rinossinusite crônica com 10 pacientes saudáveis, por meio de escovado do seio maxilar durante o ato cirúrgico, foi encontrada uma diversidade reduzida de microrganismos nos pacientes com rinossinusite crônica quando comparados aos pacientes do grupo controle. Foi identificado aumento na abundância relativa de Corynebacterium tuberculostearicum e diminuição acentuada de Lactobacillales nos pacientes com rinossinusite crônica, sugerindo uma provável ação protetora de Lactobacillales, sobretudo o Lactobacillus sakei, contra a infecção sinusal por $C$. tuberculostearicum nos pacientes normais. ${ }^{(35)}$ Em estudos posteriores, no entanto, não foi constatada a presença do Lactobacillus sakei no meato médio de pacientes normais. ${ }^{(29)}$

\subsection{Microbiologia na rinossinusite crônica}

Pacientes com rinossinusite crônica (RSC) apresentam, na maioria dos estudos, um microbioma nasossinusal com riqueza e diversidade diminuídas, quando comparados aos indivíduos sem rinossinusite. Mais importante do que isso, o equilíbrio entre os microrganismos presentes nas vias aéreas superiores parece exercer papel essencial nos seios paranasais de indivíduos sem rinossinusite. A presença de bactérias patogênicas não define, por si só, se um indivíduo tem ou não a doença, pois bactérias tipicamente associadas à rinossinusite crônica podem ser encontradas nos seios paranasais de indivíduos saudáveis, porém, em menor proporção. Esses achados sugerem que indivíduos com uma microbiota com riqueza e diversidade elevadas tendem a ser menos propensos à RSC. Um desequilíbrio nessa estrutura de comunidade bacteriana pode ser a chave para a fisiopatologia da RSC. ${ }^{(21)}$

Em um estudo brasileiro, realizado em 2007, foi comparada a cultura do meato médio de 134 pacientes com rinossinusite crônica com aquela de 50 indivíduos saudáveis. Não foi constatada diferença significativa nos microrganismos encontrados nos dois grupos. No entanto, foi identificada a presença de leucócitos no primeiro grupo e ausência no segundo. Isso pode indicar uma diferença entre microrganismos infecciosos e saprófitas. ${ }^{(36)}$ 
Em um estudo de 2016, realizado na Rússia, foram avaliados 103 pacientes com rinossinusite crônica sem polipose, por meio de cultura do swab do meato médio e do aspirado do seio maxilar. Nenhum microrganismo foi isolado em 35,7\% dos pacientes. Uma única bactéria foi isolada com mais frequência no meato médio, enquanto que a associação de mais de uma bactéria era mais comum no aspirado do seio maxilar. Bactérias anaeróbicas foram mais comumente isoladas no seio maxilar do que no meato médio. A mesma bactéria foi isolada nos dois sítios de coleta em apenas 8,9\% dos casos. Uma correlação parcial, ou seja, quando uma mesma bactéria foi isolada, mas fazia parte de uma associação de bactérias, ocorreu em $18,8 \%$ dos pacientes. ${ }^{(37)}$

À medida que as técnicas de detecção da microbiota são aprimoradas, e, especialmente, quando são utilizadas técnicas independentes de cultura, passa-se a identificar microrganismos na mucosa sinusal de pacientes considerados saudáveis e aumenta-se as informações a respeito da diversidade de microrganismos em pacientes com rinossinusite crônica. ${ }^{(38)} \mathrm{O}$ avanço em técnicas de biologia molecular e bioinformática permitiu fazer mudanças nas pesquisas na área de microbiologia referente à RSC. Se antes um único patógeno era o foco, fundamentado em métodos dependentes de cultura, atualmente existe uma visão sobre a alteração da composição da comunidade bacteriana. ${ }^{(39)}$

Ao comparar métodos de detecção molecular (Ibis Biosensor) com cultura Boase et al. ${ }^{(38)}$ encontraram bactérias em $100 \%$ das amostras de etmoide, tanto em pacientes com RSC, quanto em pacientes do grupo controle, com uma média de três bactérias por paciente com RCS e duas bactérias por paciente controle. Já a cultura foi positiva em $73 \%$ dos indivíduos com RSC e apenas em 33\% dos do grupo controle. A média da quantidade de bactérias isoladas por paciente com RSC foi de 1,3 e, nos pacientes controles com cultura positiva, apenas um organismo (Staphylococcus epidermidis) foi detectado. Os pacientes com RSC tiveram maior quantidade de genoma bacteriano detectado do que os pacientes do grupo controle. Ou seja, o grupo com RSC apresentou um aumento da abundância bacteriana em relação ao grupo controle.

Muitas hipóteses são empregadas para explicar o papel da microbiota na RSC. Uma delas propõem que a causa da doença e suas exacerbações sejam influenciadas por uma disbiose, ou seja, um desequilíbrio na comunidade bacteriana. Ainda não está bem estabelecido se essa disbiose é a causa ou a consequência do processo inflamatório. ${ }^{(39)}$ 
Por um lado, a colonização por patógenos e um desequilíbrio na microbiota pode levar a uma resposta imune crônica e consequente inflamação; por outro, uma quebra na barreira imune, uma mucosa inflamada e uma obstrução dos óstios sinusais de drenagem podem promover condições favoráveis para o crescimento bacteriano desordenado. ${ }^{(28)}$

Apesar de alguns estudos mostrarem resultados conflitantes, a maioria referente ao microbioma em RSC aponta para uma disbiose significativa, ou desequilíbrio da comunidade microbiana, com redução na riqueza, alteração na composição e abundância dos microrganismos comensais. ${ }^{(21)}$

\subsection{Microbioma na fibrose cística}

Em alguns estudos é sugerido que a diversidade do microbioma bacteriano nas vias aéreas inferiores de pacientes com fibrose cística está relacionada com uma função pulmonar melhor quando comparada com pacientes com aumento da abundância relativa de um único microrganismo, como a $P$. aeruginosa ${ }^{(2)} \mathrm{E}$, a riqueza de uma amostra de via aérea tem relação inversa com a gravidade de algumas doenças, inclusive a FC. ${ }^{(18)}$

Cox et al. ${ }^{(40)}$ avaliaram 51 pacientes estáveis com FC, na Universidade da Califórnia, São Francisco, Estados Unidos. Os adultos coletaram escarro espontâneo (37 amostras) e nos pacientes pediátricos foi coletado $s w a b$ de hipofaringe (26 amostras). $\mathrm{O}$ microbioma foi avaliado por meio da tecnologia PhyloChip ${ }^{T M}$. A maioria dos representantes encontrados pertencia aos filos Actinobacteria, Bacteroidetes, Firmicutes e Proteobacteria. O S. aureus foi detectado em $65 \%$ das amostras (61\% das amostras de adultos e $72 \%$ das amostras pediátricas) e a P. aeruginosa em $73 \%$ das amostras $(91 \%$ dos adultos e 39\% dos pediátricos). Nesse estudo, pacientes mais velhos tinham comunidades bacterianas com menor riqueza e menor diversidade, além de comunidades com agrupamentos filogenéticos mais próximos uns dos outros, quando comparados aos pacientes mais jovens. A P. aeruginosa e a Stenotrophomonas maltophilia eram mais abundantes nos pacientes mais velhos. Já o $H$. influenzae apresentava pico de abundância em pacientes mais jovens, quando a diversidade era maior. ${ }^{(40)}$

Dos pacientes com FC submetidos à cirurgia endoscópica nasal, no Centro de fibrose cística em Copenhagen, 67\% apresentaram cultura sinusal e pulmonar 
concordantes, além de $5 \%$ de pacientes em que foram encontrados patógenos típicos de FC na cultura sinusal, porém, não encontrados no pulmão, o que indica uma possível colonização precoce dos seios paranasais ou um foco mais permanente desses patógenos. ${ }^{(4)}$

Em estudo realizado na Universidade de Washington em Seattle, Estados Unidos, publicado em 2012, foram avaliadas amostras de secreção lobar de pulmões removidos durante o transplante pulmonar de 10 pacientes com fibrose cística, comparadas com amostras de escarro e orofaringe coletadas horas antes do procedimento, por meio de análise do $16 \mathrm{~S} r R N A$. A microbiota da orofaringe era diferente da microbiota do pulmão em muitos aspectos. Ela tinha um nível maior de diversidade de microrganismos e as espécies predominantes não eram as mesmas encontradas no pulmão, indicando que a microbiota orofaríngea não reflete a microbiota pulmonar nos pacientes estudados. Por outro lado, as espécies predominantes no escarro eram as mais abundantes nos pulmões. ${ }^{(41)}$

Fodor et al. ${ }^{(42)}$ avaliaram 23 pacientes adultos com FC durante uma exacerbação pulmonar, após tratamento com antibióticos e durante o período de estabilidade da doença, por meio da análise de escarro, utilizando 454 pirossequenciamentos. Após o tratamento com antibiótico de amplo espectro contra microrganismos gram-positivos e gram-negativos os pacientes apresentaram melhora clínica, com aumento de VEF1 e diminuição expressiva da contagem de leucócitos e do valor da Proteína $\mathrm{C}$ reativa. Ocorreu, também, uma redução na contagem total de bactérias viáveis e quantidade de cópias de $16 \mathrm{~S}$ rRNA no escarro. Não houve diferença na densidade bacteriana entre os períodos do início da exacerbação e estabilidade. A maioria das sequencias pertencia aos gêneros Pseudomonas (38,5\% das sequencias) e Burkholderia (21,1\% das sequencias). Os autores sugerem, também, que uma função pulmonar ruim está associada à diversidade baixa na comunidade bacteriana desses pacientes, sobretudo, no parâmetro riqueza. Contudo, os autores não observaram associação significativa entre a abundância total de bactérias e a queda na função pulmonar. ${ }^{(42)}$

Em outro estudo realizado no Hospital Universitário de Heidelberg, na Alemanha, ${ }^{(13)}$ com o objetivo de avaliar a diferença potencial na composição do microbioma nasal, da orofaringe e do escarro de crianças com FC e doença pulmonar discreta a moderada, foram avaliados 20 pacientes com média de idade de 16 anos. $\mathrm{O}$ 
microbioma nasal foi o que mostrou maior diversidade entre os três sítios analisados. A Análise das Principais Coordenadas (PCOA) mostrou que o microbioma nasal de crianças clinicamente estáveis era facilmente diferenciado do microbioma da orofaringe e do escarro. Essa diferença era ainda maior, quando eram incluídas as amostras colhidas na exacerbação. Nesse estudo, o microbioma da orofaringe e o do escarro mostraram relação estreita entre si nas crianças clinicamente estáveis, indicando a possibilidade de substituir o escarro pelo swab de orofaringe em crianças que não são capazes de expectorar. Os autores compararam os seus resultados com o estudo realizado por Fodor et al. ${ }^{(42)} \mathrm{em}$ adultos e sugeriram que a diversidade inicial do microbioma das vias aéreas inferiores de crianças se reduz e evolui para uma seleção de patógenos respiratórios potenciais, frequentemente associada com um declínio da função pulmonar na idade adulta.

Foram analisados escarros de 269 pacientes com FC, entre eles 76 pediátricos, em um estudo realizado na Universidade de Toronto, Canadá, publicado em 2015. De todas as sequências obtidas na extração e amplificação do $16 S r R N A$, apenas dois gêneros eram responsáveis por metade das sequências; e 99\% das sequências representavam, na mediana, 20 e 13 gêneros em crianças e adultos, respectivamente, ou seja, foi encontrada uma diversidade maior nas crianças do que nos adultos. Nesse estudo, um gênero dominante - isto é, gênero com maior prevalência e com, pelo menos, o dobro da abundância do segundo mais prevalente - apareceu em $45 \%$ das amostras pediátricas e em $57 \%$ das amostras de adultos. Em ordem decrescente de frequência os gêneros dominantes em crianças foram: Streptococcus, Haemophilus, Pseudomonas, Staphylococcus e Achromobacter, e em adultos foram: Pseudomonas, Burkholderia, Streptococcus, Haemophilus e Staphylococcus. A doença avançada (VEF1 <40\%) estava associada com uma menor diversidade alfa em pacientes adultos. Em crianças essa diferença não foi estatisticamente significativa. Uma análise, com auxílio de regressão linear multivariada, mostrou que a função pulmonar é influenciada negativamente pela idade, pela quantidade de antibióticos usados no dia da coleta e pela presença da Pseudomonas como gênero dominante. A função pulmonar é influenciada positivamente pela diversidade. ${ }^{(43)}$

Paganin et al. ${ }^{(11)}$ compararam pacientes portadores de FC com função pulmonar estável com aqueles com declínio substancial da função pulmonar, utilizando métodos dependentes e independentes de cultura, para avaliação da microbiota do escarro. Foram 
avaliados 78 pacientes em três centros médicos na Itália. Não detectaram diferença na diversidade microbiana entre os pacientes estáveis e os com declínio da função pulmonar. Não encontraram, ainda, diferença estatisticamente significativa na diversidade do microbioma do escarro de pacientes, quando divididos por gravidade da função pulmonar, de acordo com o VEF1.

Em estudo multicêntrico realizado na Suíça, publicado em 2016, foi avaliado o microbioma presente no swab nasal de 30 crianças com fibrose cística comparado com o de 47 crianças saudáveis, ambos grupos em seu primeiro ano de vida. O efeito do uso de antibióticos em pacientes com FC também foi avaliado. Foi observada uma divergência significativa entre as amostras de crianças com FC e as saudáveis. As amostras provenientes de crianças com FC se agrupavam de forma diferente das outras, sugerindo que a desordem da comunidade microbiana já é aparente no segundo mês de vida. Em pacientes com FC ocorre aumento significativo da família Staphylococcaceae e diminuição da família Corynebacteriaceae. A investigação do efeito de antibióticos na microbiota em pacientes enfermos mostrou mudanças persistentes, com um aumento significativo inesperado da diversidade e aumento de Staphylococcus coagulase negativo. $^{(44)}$

Em estudo publicado em 2017, efetuado na Universidade de Auckland, Nova Zelândia, foram avaliados 94 pacientes com RSC e 29 controles, mediante microbioma extraído de $s w a b$ de meato médio. Dos 94 pacientes com rinossinusite crônica, oito tinham FC. Os autores observaram que ocorreu uma redução na diversidade da comunidade bacteriana e aumento da carga bacteriana geral nos pacientes com rinossinusite crônica, particularmente mais pronunciados nos pacientes com FC. Essas diferenças, em relação ao grupo controle, foram mais características do que a dominância de uma bactéria específica. ${ }^{(45)}$

Outros estudos sugerem uma relação íntima entre as bactérias isoladas nas vias aéreas baixas e altas nos pacientes com FC, uma vez que os seios paranasais desses indivíduos são frequentemente colonizados por bactérias gram-negativas patogênicas associadas a essa doença. ${ }^{(30,46,47)}$

Na literatura não há consenso sobre a real participação da microbiota das vias aéreas superiores nas infecções pulmonares dos pacientes portadores de fibrose cística. A 
maioria dos estudos utiliza $s w a b$ nasal ou $s w a b$ de orofaringe para representar as vias aéreas superiores. Além disso, existe uma carência de estudos que descrevam o microbioma das vias aéreas de pacientes com FC no Brasil. 
4 PACIENTES E MÉTODOS 


\section{PACIENTES E MÉTODOS}

O presente estudo foi aprovado pela Comissão de Ética para Análise de Projetos de Pesquisa (CAPPesq) no dia 16 de março de 2016 (número do parecer: 1.453.561; Apêndice 1). Todos os pacientes incluídos no estudo concordaram em participar, leram e assinaram o Termo de Consentimento Livre e Esclarecido (Apêndice 2). Contou-se com apoio financeiro da Fundação de Amparo à Pesquisa do Estado de São Paulo (FAPESP), por meio do processo $\mathrm{n}^{\mathrm{o}}$ 2017/06652-0.

Trata-se de um estudo transversal exploratório, em que não houve cálculo de tamanho amostral.

Foram incluídos no estudo pacientes com 18 anos ou mais, com diagnóstico de fibrose cística comprovado por quadro clínico compatível e dosagem de cloro no suor, superior a $60 \mathrm{mEq} / \mathrm{L}$ e/ou testes genéticos com identificação de pelo menos duas mutações conhecidas.

Os critérios de exclusão foram:

- Exacerbação pulmonar nos últimos 30 dias, definida como uma mudança recente de pelo menos dois dos sete critérios:

○ Mudança na cor ou volume do escarro;

- Aumento da tosse;

○ Piora do mal-estar, fadiga ou letargia;

- Anorexia ou perda ponderal;

- Queda de $10 \%$ ou mais no VEF1;

○ Novas alterações radiológicas;

- Piora da dispneia. ${ }^{(9)}$

- Uso de antibiótico sistêmico nas últimas 4 semanas, exceto aqueles de uso contínuo e profilático;

- Transplante pulmonar prévio.

Foram recrutados 74 pacientes que frequentam o ambulatório de Fibrose Cística no setor de Pneumologia do Hospital das Clínicas da FMUSP. Quarenta e oito pacientes 
compareceram ao agendamento, entre abril de 2016 e junho de 2018. Foram excluídos da amostra: dois pacientes que usaram antibiótico oral e/ou venoso, para o tratamento de exacerbação, nas últimas quatro semanas; nove pacientes submetidos previamente a transplante pulmonar, três pacientes não concordaram a participar do estudo e dois pacientes não atenderam aos critérios para o diagnóstico para Fibrose Cística. Seis pacientes não conseguiram coletar o escarro. Durante a etapa de extração do DNA foram perdidas amostras do meato médio de 10 pacientes. Tais amostras apresentaram qualidade baixa e/ou quantidade de DNA insuficiente para análise. Esses pacientes foram convocados para nova coleta, porém, apenas um paciente compareceu (não foi possível contato telefônico com três pacientes, dois foram excluídos pois haviam sido submetidos a transplante pulmonar após a primeira coleta, dois estavam tratando exacerbação, três não concordaram em participar do estudo novamente). Restaram 31 pacientes, isto é, 17 pacientes com Volume Expiratório Forçado no Primeiro segundo (VEF1) $\geq 50$ e 14 pacientes com VEF1<40. Foi coletado um total de 22 amostras de meato médio e 26 amostras de escarro.

Os pacientes foram estratificados quanto aos parâmetros seguintes: função pulmonar; achados endoscópicos; e, medicações em uso contínuo. Para tanto, foram submetidos à prova de função pulmonar, endoscopia nasal com endoscópio rígido de $0^{\circ}$. Além disso, responderam aos questionários validados para língua portuguesa relacionados a sintomas nasossinusais, $\operatorname{NOSE}^{(49)}$ (Anexo A), SNOT 20 ${ }^{(48)}$ (Anexo B) e ao questionário de qualidade de vida específico para Fibrose Cística (QFC-R 14+) ${ }^{(50)}$ (Anexo C). A endoscopia nasal foi classificada de acordo com a classificação de LundKennedy ${ }^{(51)}$ (Anexo D).

\subsection{Coleta das amostras}

Foram coletadas amostras de swab de meato médio e escarro dos pacientes durante visita de rotina ao ambulatório de Fibrose Cística do setor de Pneumologia do HCFMUSP.

O swab utilizado na coleta foi o FLOQSwabs (COPAN Diagnostics, Inc., Murrieta, CA, Estados Unidos). Trata-se de swab específico com cerdas que permitem 
coleta de maior quantidade de material genético e melhor liberação do mesmo para análise, quando comparado a um swab de algodão comum.

Foi realizada assepsia do vestíbulo com iodopolividona tópica. Não foi utilizado nenhum tipo de anestésico tópico ou vasoconstritor. O swab era protegido por uma sonda para evitar o contato com o vestíbulo nasal e diminuir a contaminação da amostra. Sob visualização com endoscópio rígido de $4 \mathrm{~mm}$ e $0^{\circ}$ acoplado a um sistema de vídeo, o $s w a b$ encapado por uma sonda estéril de aspiração traqueal número 12 foi levado até o meato médio. Já no meato médio, o swab foi desencapado para coleta da amostra, com, pelo menos, três rotações completas dentro do meato. Após esse procedimento, o swab foi encapado novamente e retirado do nariz. Para a coleta, foi escolhida a fossa nasal mais ampla e que oferecia maior facilidade para chegar ao meato médio, de acordo com os parâmetros anatômicos visualizados na endoscopia nasal prévia. Todas as coletas de meato médio foram realizadas pelo mesmo examinador, exceção feita ao paciente que foi submetido a uma segunda coleta, realizada por outro examinador.

Imediatamente após a coleta, a ponta do swab foi desencapada novamente e cortada com uma tesoura estéril, acomodada em um criotubo estéril, livre de DNAase e RNAase, tampado e colocado em um cooler com gelo.

As amostras de escarro foram coletadas pelos próprios pacientes em frasco estéril. Cerca de $1,5 \mathrm{~mL}$ da amostra foram aspirados com seringa estéril e transferidos para o criotubo, e também colocados no cooler com gelo.

Em até 2 horas, as amostras foram levadas para armazenamento a uma temperatura de $-80^{\circ} \mathrm{C}$, no freezer do Laboratório de Investigação Médica (LIM) do Departamento de Otorrinolaringologia, da FMUSP. Posteriormente foram encaminhadas ao Laboratório de Biologia Molecular do Hospital Universitário da USP, onde foram realizados: extração do DNA; amplificação por PCR; e, sequenciamento de nova geração, para identificação do microbioma. 


\subsection{Extração de DNA Bacteriano}

O DNA total das amostras coletadas foi extraído com o kit QiaAmp DNA Blood (Quiagen) e armazenado a $-20^{\circ} \mathrm{C}$ até o momento da análise. As amostras de escarro precisaram ser tratadas com uma solução de Dithiothreitol (DTT - sputolisina) a $0,1 \%$ antes da etapa de extração do DNA. ${ }^{(52,53)}$

Para uma análise global da composição de bactérias presentes no meato médio e no escarro dos pacientes, o DNA extraído das amostras foi utilizado nas reações de sequenciamento, capazes de identificar corretamente os membros de uma comunidade microbiana. ${ }^{(27)}$ Foi avaliada a região V3 e V4 do $16 S$ rRNA para identificação dos microrganismos.

\subsection{Sequenciamento de Nova Geração}

Após a extração de DNA, a caracterização da microbiota foi realizada pela amplificação dos domínios V3 e V4 do segmento 16S ribossômico bacteriano com metodologia de sequenciamento por High-throughput MiSeq ${ }^{\circledR}$ (Illumina). Os primers utilizados para a amplificação do gene $16 S$ rRNA foram previamente descritos por Klindworth et al. ${ }^{(54)}$. O comprimento total de sequências iniciadoras, utilizando a nomenclatura de nucleótidos IUPAC padrão, para seguir o protocolo para esta região são:

- 16S Forward Primer 5' - TCGTCGGCAGCGTCAGATGTGTATAAGAGACAGCC

TACGGGNGGCWGCAG

- 16S Reverse Primer 5' - GTCTCGTGGGCTCGGAGATGTGTATAAGAGACAGG ACTACHVGGGTATCTAATCC

Todos os procedimentos foram feitos conforme o protocolo do fabricante (Illumina - 16S Metagenomic Sequencing Library Preparation). ${ }^{(55)}$ 


\subsection{Amplificação de sequências-alvo}

Para a amplificação das sequencias-alvo, foram utilizados $2,5 \mu \mathrm{L}$ de DNA microbiano (5ng/mL), $5 \mu \mathrm{L}$ de Amplicon PCR Forward Primer $(1 \mu \mathrm{M}), 5 \mu \mathrm{L}$ de Amplicon PCR Reverse Primer $(1 \mu \mathrm{M})$ e $12,5 \mu \mathrm{L}$ de $2 x$ KAPA HiFi Hot Start Ready Mix, obtendose um volume total de $25 \mu \mathrm{L}$. Foi realizada ativação da enzima a $95^{\circ} \mathrm{C}$ por $3 \mathrm{~min}$, em seguida 25 ciclos de desnaturação a $95^{\circ} \mathrm{C}$ por 30 s, anelamento a $55^{\circ} \mathrm{C}$ por 30 s, extensão a $72^{\circ} \mathrm{C}$ por $30 \mathrm{~s}$, a $72^{\circ} \mathrm{C}$ por $5 \mathrm{~min}$, e, finalmente, a enzima foi mantida a $4^{\circ} \mathrm{C} . \mathrm{O}$ aquecimento/esfriamento foi efetuado em termociclador.

Foi utilizado $1 \mu \mathrm{L}$ do produto para eletroforese em gel de agarose a $1 \%$, com o objetivo de verificar se o PCR amplificou até o tamanho esperado, após a utilização dos pares de primer V3/V4 no protocolo ( 412 pares de base), além de avaliar a qualidade do DNA.

\subsection{Purificação dos produtos da PCR}

A purificação do produto da amplificação da região $16 S$ rRNA V3 e V4 de primers e outros artefatos de PCR (primer dimers) foi feita com o sistema AMPure XP (Beckman Coulter Agencourt Beads). Foram adicionados $20 \mu \mathrm{L}$ de esferas AMPure XP em cada poço da placa de PCR com uma pipeta multicanal. A placa foi incubada em temperatura ambiente por 5 min e colocada em uma estante magnética por $2 \mathrm{~min}$.

O sobrenadante foi, então, removido e descartado. Em cada poço foram adicionados $200 \mu \mathrm{L}$ de etanol a $80 \%$ para lavar as esferas. A placa permaneceu incubada no suporte magnético por 30s e o sobrenadante foi cuidadosamente removido. A lavagem com etanol foi repetida. Com a placa ainda no suporte magnético, as esferas ficaram secando ao ar ambiente por $10 \mathrm{~min}$.

Em seguida, a placa foi retirada do suporte magnético, e, com uma pipeta multicanal, adicionou-se $52,5 \mu \mathrm{L}$ de Tris $10 \mathrm{mM}(\mathrm{pH} 8,5)$ em cada poço da placa. Após ressuspender, a placa foi incubada em temperatura ambiente por $2 \mathrm{~min}$, e então colocada 
novamente na estante magnética por mais $2 \mathrm{~min}$. Finalmente, $50 \mu \mathrm{L}$ do sobrenadante foram, cuidadosamente, transferidos para uma nova purificação de PCR.

\subsection{Reação de PCR para anexar os adaptadores}

Para anexar dois índices e adaptadores de sequenciamento (Illumina Nextera XT Index), foram utilizados $5 \mu \mathrm{L}$ de cada poço da placa obtida na etapa anterior, e transferidos para uma nova placa de PCR. Nessa nova placa, foram adicionados $5 \mu \mathrm{L}$ do Index Primer $1(N 7 x x), 5 \mu \mathrm{L}$ do Index Primer $2(S 5 x x), 25 \mu \mathrm{L}$ de $2 x$ KAPA HiFi Hot Start Ready Mix e $10 \mu \mathrm{L}$ de água para PCR. A reação foi realizada nas condições seguintes: ativação da enzima a $95^{\circ} \mathrm{C}$ por $3 \mathrm{~min}$, seguidos de oito ciclos de desnaturação a $95^{\circ} \mathrm{C}$ por $30 \mathrm{~s}$, anelamento a $55^{\circ} \mathrm{C}$ por $30 \mathrm{~s}$, extensão a $72^{\circ} \mathrm{C}$ por $30 \mathrm{~s}, 72^{\circ} \mathrm{C}$ por 5 min e mantidos a $4^{\circ} \mathrm{C}$.

\subsection{Purificação da biblioteca final}

Nesta etapa utiliza-se esferas do sistema AMPure XP (Beckman Coulter Agencourt Beads) para purificar a biblioteca final antes da quantificação.

Com uma pipeta multicanal, foram adicionados $56 \mu \mathrm{L}$ das esferas AMPure XP na placa de PCR proveniente da etapa anterior. Após a homogeneização, a placa foi incubada em temperatura ambiente por $5 \mathrm{~min}$. Então, a placa foi colocada em uma estante magnética por $2 \mathrm{~min}$, ou até que o sobrenadante estivesse limpo.

Com a placa no suporte magnético, o sobrenadante foi removido e descartado. Foram, então, adicionados $200 \mu \mathrm{L}$ de etanol a $80 \%$ em cada poço para lavar as esferas; a placa permaneceu incubada no suporte magnético por 30s, e, em seguida, o sobrenadante foi cuidadosamente removido. A lavagem com etanol foi repetida posteriormente. Com a placa ainda no suporte magnético, as esferas ficaram secando ao ar por 10min. Em seguida, a placa foi retirada da estante magnética, e foram adicionados $27,5 \mu \mathrm{L}$ de Tris $10 \mathrm{mM}(\mathrm{pH} 8,5)$ em cada poço da placa. Após suspender novamente, a placa foi incubada em temperatura ambiente por $2 \mathrm{~min}$, e então colocada novamente na estante magnética 
por $2 \mathrm{~min}$, ou até que o sobrenadante estivesse limpo. Finalmente, cuidadosamente foram transferidos $25 \mu \mathrm{L}$ do sobrenadante para uma nova placa de PCR.

\subsection{Preparo do pool equimolar das bibliotecas amplificadas}

$\mathrm{O}$ agrupamento das amostras em quantidades equimolares permite a total cobertura das regiões-alvo. A quantificação das amostras foi realizada no equipamento Qubit $^{\circledR} 2.0$ Fluorometer (Thermo Fisher Scientific), que mede a fluorescência específica do alvo. Em seguida, calculou-se a concentração de DNA em unidades nM, e diluiu-se a biblioteca final concentrada usando Tris $10 \mathrm{mM}(\mathrm{pH} 8,5)$ para a concentração de $4 \mathrm{nM}$. Então, aliquotou-se $5 \mu \mathrm{L}$ do DNA diluído de cada biblioteca e misturou-se as alíquotas para criar um "pool" de bibliotecas com índices únicos de todas as amostras.

As bibliotecas agrupadas foram desnaturadas com hidróxido de sódio, diluídas com tampão de hibridização a uma concentração final de 15pM, e, em seguida, desnaturadas em temperatura de $96^{\circ} \mathrm{C}$ antes do sequenciamento MiSeq. A corrida incluiu $20 \%$ de PhiX para servir como um controle interno para essas bibliotecas de diversidade baixa.

Posteriormente, o "pool" das bibliotecas foi encaminhado para sequenciamento no equipamento Illumina ${ }^{\circledR}$ Miseq, utilizando o kit MiSeq Reagent Kit v2 (500 ciclos).

\subsection{Processamento das sequencias obtidas por bioinformática}

Após a obtenção das sequências, foi feita a demultiplexação das amostras de acordo com as sequências dos barcodes. As sequências obtidas foram comparadas com as presentes em um banco de dados de sequências conhecidas de 16S e, por comparação, foram identificados os gêneros a que pertencem. 


\subsection{Análise dos resultados}

Os resultados obtidos pela metodologia de sequenciamento por high throughput oferecem uma visão panorâmica da composição predominante da microbiota do meato médio e do escarro dos pacientes incluídos no estudo.

Foi utilizado um conjunto de ferramentas disponíveis no software QIIME v.1.9.1 (Quantitative Insights Into Microbial Ecology) ${ }^{(57)}$ para análise da comunidade microbiana, incluindo filtro de qualidade das sequências, agrupamento em Unidades Taxonômicas Operacionais (OTU), atribuição taxonômica, medida das diversidades alfa e beta. ${ }^{(27)}$

Por meio de recursos de bioinformática, as sequências obtidas a partir da extração do material genético são agrupadas em OTU de acordo com o grau de semelhança. As OTUs são grupos de sequências de $16 S$ rRNA com pelo menos $97 \%$ de similaridade, usadas para definir determinada unidade taxonômica (gênero/espécie) ${ }^{(21,58)}$; essas OTUs foram comparadas ao banco de dados Silva versão $128^{(59)}$, para identificação das bactérias. Esses dados são plotados em uma tabela e, para descrição da composição do microbioma, foram utilizados alguns parâmetros: Diversidade alfa e beta, índice de Shannon, Índice de riqueza Chao1, curvas de rarefação, Análise de Coordenadas Principais $(\mathrm{PCOA}){ }^{(60)}$

A diversidade alfa avalia a composição de microrganismos em cada amostra, por meio do Shannon index, que possibilita determinar quais e quantos tipos de microrganismos existem nos sítios avaliados. ${ }^{(61)} \mathrm{O}$ índice de riqueza Chao 1 avalia a riqueza da amostra, ou seja, a quantidade de espécies ou gêneros identificados em cada amostra, sem levar em consideração a abundância relativa de cada uma delas. ${ }^{(62)} \mathrm{O}$ índice de Simpson avalia a dominância. ${ }^{(63)}$

A diversidade beta possibilita comparar a composição do microbioma de pacientes de dois grupos distintos, por meio do teste UniFrac, que avalia estatisticamente as diferenças na estrutura da comunidade bacteriana entre os pontos de análise, e permite identificar as linhagens com história evolutiva em comum. ${ }^{(64,65)}$

A Análise das Principais Coordenadas (PCoA) é uma representação gráfica, que permite a análise de um dado multidimensional projetado em um plano bidimensional. É 
usada para avaliação das diferenças entre as amostras dos grupos. Esse teste pode ser aplicado quando as relações entre as variáveis não são lineares. As variáveis são plotadas em um gráfico e avaliadas semelhanças e diferenças entre as comunidades de bactérias de diferentes indivíduos e/ou grupos de indivíduos.

\subsection{Análise estatística}

4.11.1 Análise estatística das características demográficas e clínicas dos pacientes

As variáveis contínuas foram descritas como médias e seus respectivos desviospadrão (DP) e as categóricas em porcentagens. Após a verificação da normalidade pelo teste de Shapiro-Wilk, a idade, os escores de Lund-Kennedy, as pontuações do SNOT-20 e do NOSE foram comparadas entre os grupos pelo teste não-paramétrico de WilcoxonMann-Whitney. As comparações entre as diferentes proporções de gênero, uso de alfa dornase e antibióticos foram realizadas pelo teste Exato de Fisher, considerando o resultado estatisticamente significativo quando $\mathrm{p}<0,05$.

\subsubsection{Análise estatística do microbioma}

A análise estatística foi realizada com auxílio do programa SPSS versão 22. O teste utilizado foi o modelo linear generalizado (GLzM), no qual foi avaliado o efeito das variáveis independentes (grupos) sobre as variáveis dependentes (índices de alfa diversidade e filos e gêneros bacterianos). Para os índices de alfa diversidade foi utilizada a distribuição gama e para os filos e gêneros bacterianos foi utilizada a distribuição linear. Os índices de alfa diversidade analisados foram: Chao1 para estimar a riqueza e Shannon e Simpson para estimar a diversidade. O software Microbiome Analyst ${ }^{(66)}$ foi utilizado para observar as diferenças na beta diversidade entre os tipos de amostra, gravidade da doença, uso de dornase alfa, uso de antibiótico inalatório e uso de antibiótico oral profilático. O teste PERMANOVA foi realizado para cada variável utilizando as distâncias UniFrac ponderadas e não ponderadas. Para cada variável, foram feitas 999 permutações. Para todas as análises, o nível de significância considerado foi $p \leq 0,05$. 
5 RESULTADOS 


\section{RESULTADOS}

\subsection{Caracterização do Grupo amostral}

No presente estudo foram incluídos 31 pacientes. Dezessete pacientes com Volume Expiratório Forçado no primeiro segundo (VEF1) $\geq 50$ (doença pulmonar discreta/moderada) e 14 com VEF1 < 40 (doença pulmonar grave). Dos 31 pacientes foram coletadas, no total, 22 amostras de meato médio e 26 de escarro.

Conforme a Tabela 1, os grupos não variaram com relação à idade, gênero, escores nos questionários de Lund-Kennedy, SNOT-20 e NOSE ( $p>0,05)$. Houve uma tendência de maior uso de dornase alfa no grupo com doença pulmonar grave, porém não era estatisticamente significativo ( $\mathrm{p}=0,27)$. Não houve diferença entre os grupos quanto ao uso de antibiótico oral profilático (Azitromicina, 3 vezes por semana). O grupo com doença pulmonar grave estava utilizando, proporcionalmente, mais antibiótico inalatório (Tobramicina ou Colistina) $(\mathrm{p}<0,01)$. 
Tabela 1. Características demográficas e clínicas dos pacientes dos dois grupos com diferentes estágios da doença.

\begin{tabular}{lcccc}
\hline & Total & $\begin{array}{c}\text { Grupo 1: } \\
\text { VEF1 } \geq \mathbf{5 0}\end{array}$ & $\begin{array}{c}\text { Grupo 2: } \\
\text { VEF1 < 40 }\end{array}$ & p* \\
\hline Sujeitos (n) & 31 & 17 & 14 & - \\
\hline Idade (média, DP) & $30,2(14,8)$ & $29,5(14,8)$ & $31,1(15,4)$ & 0,33 \\
\hline Gênero (m=masculino, f=feminino) & $13 \mathrm{~m}, 18 \mathrm{f}$ & $8 \mathrm{~m}, 9 \mathrm{f}$ & $5 \mathrm{~m}, 9 \mathrm{f}$ & 0,7 \\
\hline Dornase alfa & $58,1 \%$ & $47,1 \%$ & $71,4 \%$ & 0,27 \\
\hline Antibiótico inalatório & $41,9 \%$ & $17,6 \%$ & $71,4 \%$ & $<0,01$ \\
\hline Antibiótico oral & $71,0 \%$ & $64,7 \%$ & $78,6 \%$ & 0,46 \\
\hline Lund-Kennedy*** & 3,9 & $4,0(2,6)$ & $3,9(3,1)$ & 0,95 \\
\hline SNOT-20*** & 31,6 & $32,0(21,3)$ & $31,6(17,2)$ & 0,98 \\
\hline NOSE**** & 7,0 & $7,1(6,1)$ & $7,2(5,4)$ & 0,87 \\
\hline
\end{tabular}

p* valor-p baseado nos testes de Wilcoxon-Mann-Whitney e Exato de Fisher; ** Classificação endoscópica de Lund-Kennedy; *** Sino-Nasal Outcome Test-20; **** Nose Obstruction Symptom Evaluation.

\subsection{Caracterização do Microbioma}

5.2.1 Abundância Relativa - Filos e Gêneros bacterianos

\subsubsection{Por tipo de amostra}

A abundância relativa dos filos das amostras de meato médio e escarro pode ser observada na Tabela 2 e Figura 1.

Os filos bacterianos mais abundantes nas amostras de meato médio e escarro podem ser observados na Figura 1. Com relação às amostras de meato médio, o filo mais abundante observado foi Firmicutes $(51,47 \%)$, seguido por Proteobacteria $(28,40 \%)$ e Actinobacteria $(13,10 \%)$; nas amostras de escarro, o principal filo observado foi Proteobacteria $(59,10 \%)$, seguido de Firmicutes $(20,68 \%)$ e Bacterioidetes $(13,00 \%)$. 
Tabela 2. Abundância relativa dos principais filos nas amostras de meato médio e escarro.

\begin{tabular}{l|c|c}
\hline Microbiota (Filos) & $\begin{array}{c}\text { Meato Médio } \\
(\boldsymbol{\%})\end{array}$ & $\begin{array}{c}\text { Escarro } \\
(\boldsymbol{\%})\end{array}$ \\
\hline Firmicutes & 51,47 & 20,68 \\
Bacteroidetes & 4,00 & 13,00 \\
Proteobacteria & 28,40 & 59,10 \\
Actinobacteria & 13,10 & 0,90 \\
Fusobacteria & 1,60 & 4,80 \\
Outros & 1,43 & 1,52 \\
\hline
\end{tabular}

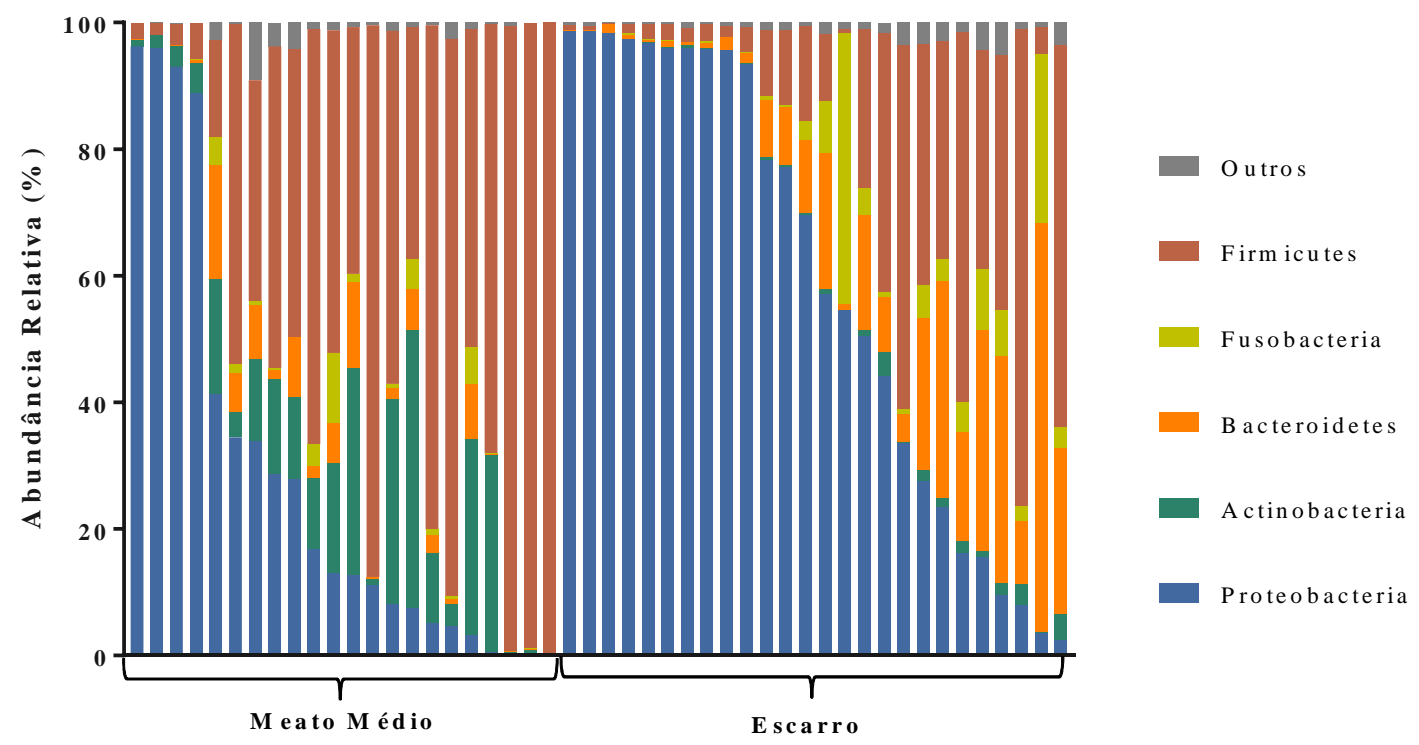

Figura 1. Principais filos encontrados nas amostras de meato médio e escarro em cada paciente

A abundância relativa dos gêneros das amostras de meato médio e escarro pode ser observada nas Figuras 2 e 3, e Tabela 3.

Na Figura 2, são ressaltados os resultados individuais para os pacientes, referentes às amostras clínicas estudadas. Nota-se uma diferença no perfil microbiano entre os materiais coletados, com uma prevalência de Streptococcus e Staphylococcus e nas amostras de meato médio, e Pseudomonas e Prevotella nas amostras de escarro. Quando comparadas as médias de cada gênero entre as amostras de meato médio e escarro, os 
principais gêneros encontrados foram Streptococcus (22,30\%), Staphylococcus (20,90\%), Corynebacterium (8,60\%) e Pseudomonas (6,88\%) no meato médio, e Pseudomonas $(44,10 \%)$, Haemophilus $(11,22 \%)$, Veillonella $(6,85 \%)$ e Prevotella $(6,40 \%)$ nas amostras de escarro (Tabela 3 e Figura 3).

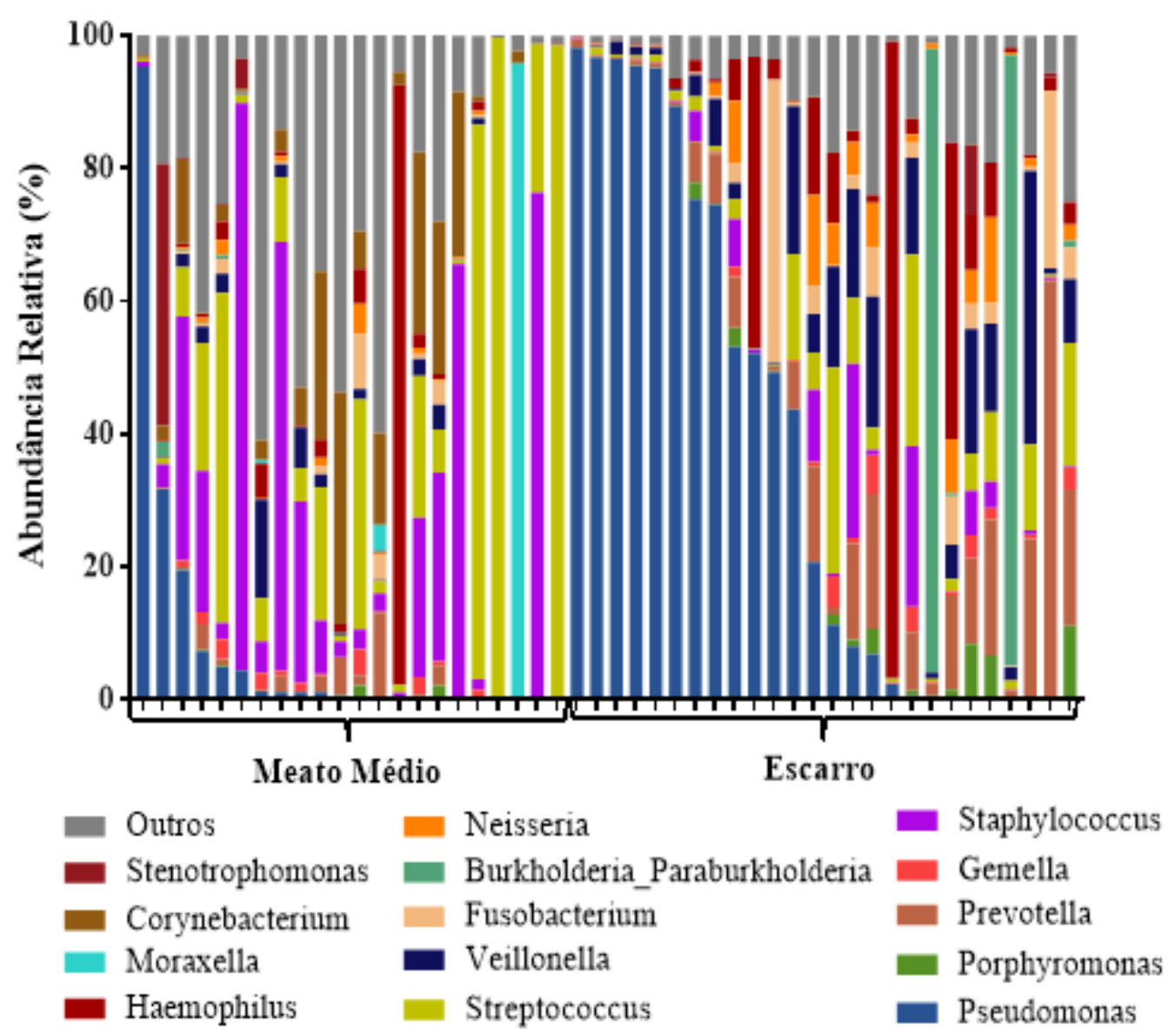

Figura 2. Principais gêneros bacterianos encontrados nas amostras de meato médio e escarro, em cada paciente 


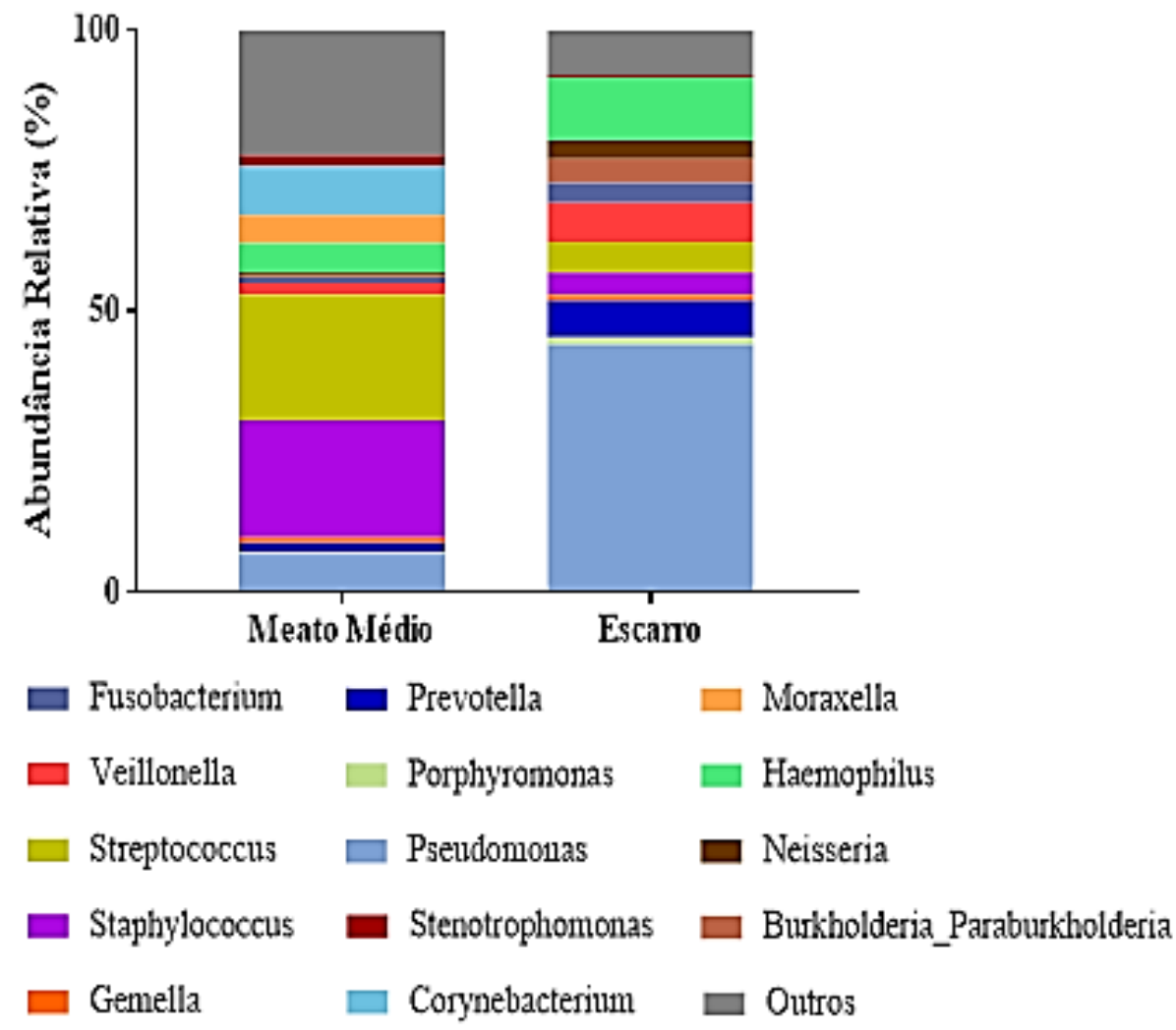

Figura 3. Média dos principais gêneros bacterianos encontrados por sítio de coleta

Tabela 3. Abundância relativa dos principais gêneros nas amostras de meato médio e escarro.

\begin{tabular}{l|c|c}
\hline Microbiota (Gêneros) & $\begin{array}{c}\text { Meato Médio } \\
(\%)\end{array}$ & $\begin{array}{c}\text { Escarro } \\
(\%)\end{array}$ \\
\hline Pseudomonas & 6,88 & 44,10 \\
Porphyromonas & 0,22 & 1,30 \\
Prevotella & 1,72 & 6,40 \\
Gemella & 0,93 & 1,12 \\
Staphylococcus & 20,90 & 3,90 \\
Streptococcus & 22,30 & 5,60 \\
Veillonella & 2,04 & 6,85 \\
Fusobacterium & 1,07 & 3,50 \\
Burkholderia_Paraburkholderia & 0,20 & 4,30 \\
Neisseria & 0,60 & 3,30 \\
Haemophilus & 5,2 & 11,22 \\
Moraxella & 5,02 & 0,01 \\
Corynebacterium & 8,60 & 0,01 \\
Stenotrophomonas & 2,00 & 0,43 \\
Outros & 22,32 & 7,96 \\
\hline
\end{tabular}




\subsubsection{Por função pulmonar (Gravidade da doença pulmonar)}

Os filos e gêneros bacterianos foram avaliados estatisticamente em cada tipo de amostra, para cada grupo dividido pela gravidade da doença pulmonar de acordo com VEF1 (VEF1 $\geq 50 \%$ : grupo 1 - doença pulmonar discreta a moderada; e VEF1 $\leq 40 \%$ : grupo 2 - doença pulmonar grave) nos pacientes com fibrose cística. Os resultados da análise dos filos principais das amostras de meato médio podem ser observados na Tabela 4.

Ao avaliar as amostras de meato médio, constatou-se que os pacientes no grupo com doença pulmonar considerada grave apresentaram maior proporção do filo Firmicutes $(47,46$ x 57,24; $p=0,47)$ e menor proporção dos filos Proteobacteria $(30,61$ x $25,11 ; \mathrm{p}=0,69)$, Actinobacteria $(14,74 \times 10,80 ; \mathrm{p}=0,47)$, Bacteroidetes $(4,31 \times 3,53$; $\mathrm{p}=0,71)$ e Fusobacteria $(2,00 \times 1,07 ; \mathrm{p}=0,41)$ em comparação com o grupo com gravidade da doença pulmonar discreta a moderada, porém nenhum dos resultados alcançou significância estatística.

Tabela 4. Abundância relativa dos filos principais nas amostras de meato médio de acordo com a gravidade da doença pulmonar.

\begin{tabular}{|c|c|c|c|c|}
\hline \multirow{2}{*}{ Microbiota (Filo) } & & \multicolumn{2}{|c|}{ Gravidade da doença pulmonar } & \multirow{2}{*}{$p^{\mathbf{a}}$} \\
\hline & & Discreta a moderada & Grave & \\
\hline \multirow{3}{*}{ Firmicutes } & Mín.-Máx. & $2,0-98,5$ & $5,7-99,9$ & \multirow{3}{*}{0,47} \\
\hline & Média & 47,46 & 57,24 & \\
\hline & Desvio Padrão & 32,50 & 33,18 & \\
\hline \multirow{3}{*}{ Bacteroidetes } & Mín.-Máx. & $0-13,6$ & $0-18,1$ & \multirow{3}{*}{0,71} \\
\hline & Média & 4,31 & 3,53 & \\
\hline & Desvio Padrão & 4,48 & 6,09 & \\
\hline \multirow{3}{*}{ Proteobacteria } & Mín.-Máx. & $0,4-96,2$ & $0-88.9$ & \multirow{3}{*}{0,69} \\
\hline & Média & 30,61 & 25,11 & \\
\hline & Desvio Padrão & 38,06 & 28,14 & \\
\hline \multirow{3}{*}{ Actinobacteria } & Mín.-Máx. & $0.1-43,8$ & $0.1-31,0$ & \multirow{3}{*}{0,47} \\
\hline & Média & 14,74 & 10,8 & \\
\hline & Desvio Padrão & 15,21 & 9,9 & \\
\hline \multirow{3}{*}{ Fusobacteria } & Mín.-Máx. & $0-11,1$ & $0-17.3$ & \multirow{3}{*}{0,41} \\
\hline & Média & 2,0 & 1,07 & \\
\hline & Desvio Padrão & 3,31 & 1,65 & \\
\hline
\end{tabular}

$\mathrm{p}^{\mathrm{a}}$ valor-p Modelo Linear Generalizado (GLzM) - Significante quando $p \leq 0,05$. 
Os resultados da análise dos gêneros mais abundantes nas amostras de meato médio podem ser observados na Tabela 5 e Figuras 4 e 5 .

Observa-se que o meato médio dos pacientes no grupo com função pulmonar considerada grave apresentaram maior proporção na abundância dos gêneros Staphylococcus $(19,76$ x 22,48; $\mathrm{p}=0,81)$, Streptococcus $(18,46 \times 27,91 ; \mathrm{p}=0,47) \mathrm{e}$ Stenotrophomonas $(0,007 \times 4,95 ; \mathrm{p}=0,14)$, enquanto que apresentaram menor proporção dos gêneros Pseudomonas (8,24 x 6,91; p=0,76), Haemophilus $(8,00$ x 1,18; p=0,39) e Corynebacterium $(10,00 \times 6,65 ; \mathrm{p}=0,46)$ em comparação com o grupo com gravidade da função pulmonar discreta à moderada, porém nenhum dos resultados apresentou significância estatística. Esses resultados foram obtidos com as médias de abundância relativa dos gêneros encontrados em cada grupo (Tabela 5). Porém, quando foi avaliada a abundância relativa dos gêneros em cada indivíduo, foi notado um outro perfil de microbioma (Figura 5). Os gêneros Staphylococcus e Streptococcus estão presentes em ambos os grupos, com abundâncias semelhantes. No grupo de função pulmonar discreta a moderada, apenas um paciente apresentou colonização por Pseudomonas, mas em uma abundância maior que $90 \%$. No grupo grave, cinco pacientes apresentaram o gênero Pseudomonas como colonizador, mas menos abundante. 
Tabela 5. Abundância relativa dos principais gêneros nas amostras de meato médio de acordo com a gravidade da doença pulmonar.

\begin{tabular}{|c|c|c|c|c|}
\hline \multirow{2}{*}{ Microbiota (Gêneros) } & & \multicolumn{2}{|c|}{ Gravidade da doença pulmonar } & \multirow{2}{*}{$p^{\mathrm{a}}$} \\
\hline & & Discreta a moderada & Grave & \\
\hline \multirow{3}{*}{ Pseudomonas } & Mín.-Máx. & $0-95,3$ & $0-31,7$ & \multirow{3}{*}{0,76} \\
\hline & Média & 8,24 & 6,91 & \\
\hline & Desvio Padrão & 26,22 & 11,18 & \\
\hline \multirow{3}{*}{ Porphyromonas } & Mín.-Máx. & $0-2,0$ & $0-0,2$ & \multirow{3}{*}{0,16} \\
\hline & Média & 0,31 & 0,04 & \\
\hline & Desvio Padrão & 0,68 & 0,07 & \\
\hline \multirow{3}{*}{ Prevotella } & Mín.-Máx. & $0-5,7$ & $0-12,8$ & \multirow{3}{*}{0,70} \\
\hline & Média & 1,51 & 1,66 & \\
\hline & Desvio Padrão & 1,85 & 4,18 & \\
\hline \multirow{3}{*}{ Gemella } & Mín.-Máx. & $0-3,90$ & $0-3,0$ & \multirow{3}{*}{0,98} \\
\hline & Média & 0,9 & 0,88 & \\
\hline & Desvio Padrão & 1,22 & 1,12 & \\
\hline \multirow{3}{*}{ Staphylococcus } & Mín.-Máx. & $0-76,3$ & $0,1-85,4$ & \multirow{3}{*}{0,81} \\
\hline & Média & 19,76 & 22,48 & \\
\hline & Desvio Padrão & 25,13 & 32,42 & \\
\hline \multirow{3}{*}{ Streptococcus } & Mín.-Máx. & $0-98,3$ & $0,5-99,5$ & \multirow{3}{*}{0,47} \\
\hline & Média & 18,46 & 27,91 & \\
\hline & Desvio Padrão & 26,35 & 39,45 & \\
\hline \multirow{3}{*}{ Veillonella } & Mín.-Máx. & $0-6,0$ & $0-14,8$ & \multirow{3}{*}{0,57} \\
\hline & Média & 1,59 & 2,36 & \\
\hline & Desvio Padrão & 1,80 & 4,77 & \\
\hline \multirow{3}{*}{ Fusobacterium } & Mín.-Máx. & $0-8,40$ & $0-3,70$ & \multirow{3}{*}{0,65} \\
\hline & Média & 1,13 & 0,76 & \\
\hline & Desvio Padrão & 2,40 & 1,31 & \\
\hline \multirow{3}{*}{$\begin{array}{l}\text { Burkholderia- } \\
\text { Paraburkholderia }\end{array}$} & Mín.-Máx. & $0-0,1$ & $0-2,30$ & \multirow{3}{*}{0,056} \\
\hline & Média & 0,007 & 0,37 & \\
\hline & Desvio Padrão & 0,02 & 0,74 & \\
\hline \multirow{3}{*}{ Neisseria } & Mín.-Máx. & $0-4,40$ & $0-2,32$ & \multirow{3}{*}{0,65} \\
\hline & Média & 0,66 & 0,46 & \\
\hline & Desvio Padrão & 1,20 & 0,72 & \\
\hline \multirow{3}{*}{ Haemophilus } & Mín.-Máx. & $0-90,2$ & $0-5,20$ & \multirow{3}{*}{0,39} \\
\hline & Média & 8,0 & 1,18 & \\
\hline & Desvio Padrão & 24,74 & 1,75 & \\
\hline & Mín.-Máx. & $0-95,8$ & $0-4,0$ & \\
\hline Moraxella & Média & 7,36 & 0,51 & 0,42 \\
\hline & Desvio Padrão & 26,57 & 1,32 & \\
\hline & Mín.-Máx. & $0,1-34,8$ & $0-24,9$ & \\
\hline Corynebacterium & Média & 10,0 & 6,65 & 0,46 \\
\hline & Desvio Padrão & 12,61 & 8,58 & \\
\hline & Mín.-Máx. & $0-0,1$ & $0-39,5$ & \\
\hline Stenotrophomonas & Média & 0,007 & 4,95 & 0,14 \\
\hline & Desvio Padrão & 0,02 & 13,03 & \\
\hline
\end{tabular}

$\mathrm{p}^{\mathrm{a}}$ valor-p Modelo Linear Generalizado (GLzM) - Significante quando $p \leq 0,05$ 
Discreta a moderada Grave \%

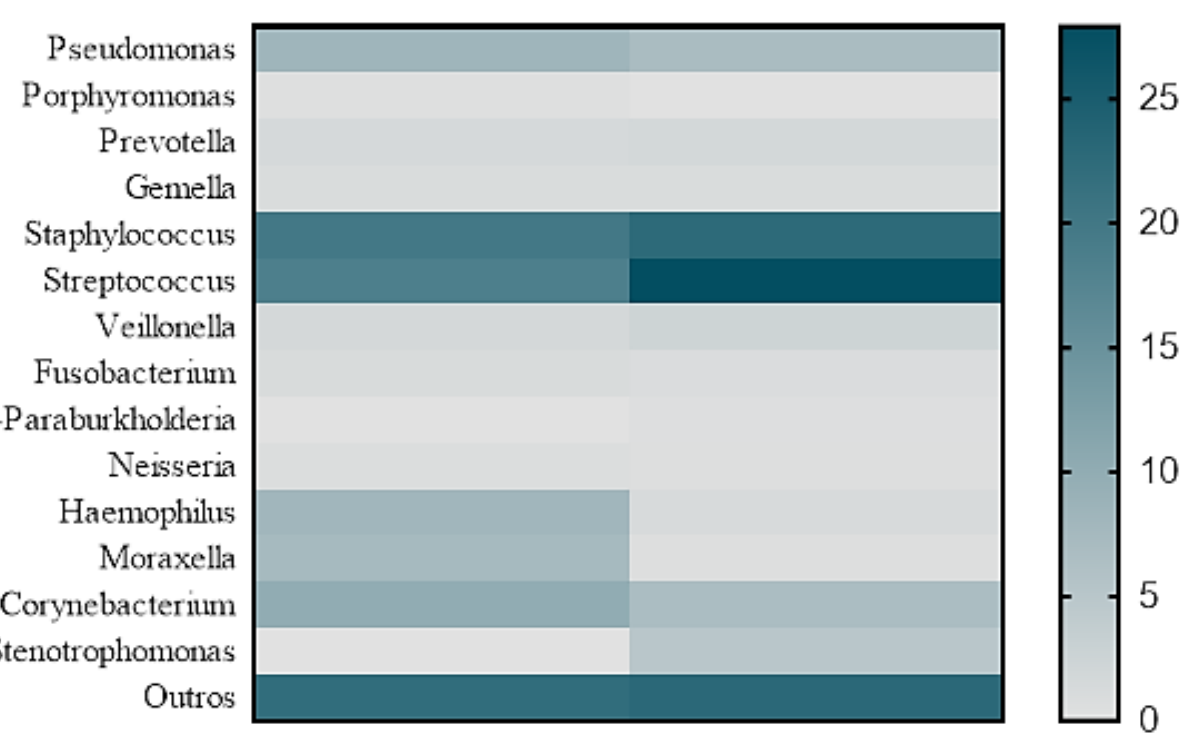

Figura 4. Gêneros bacterianos nas amostras de meato médio de acordo com a gravidade da doença pulmonar

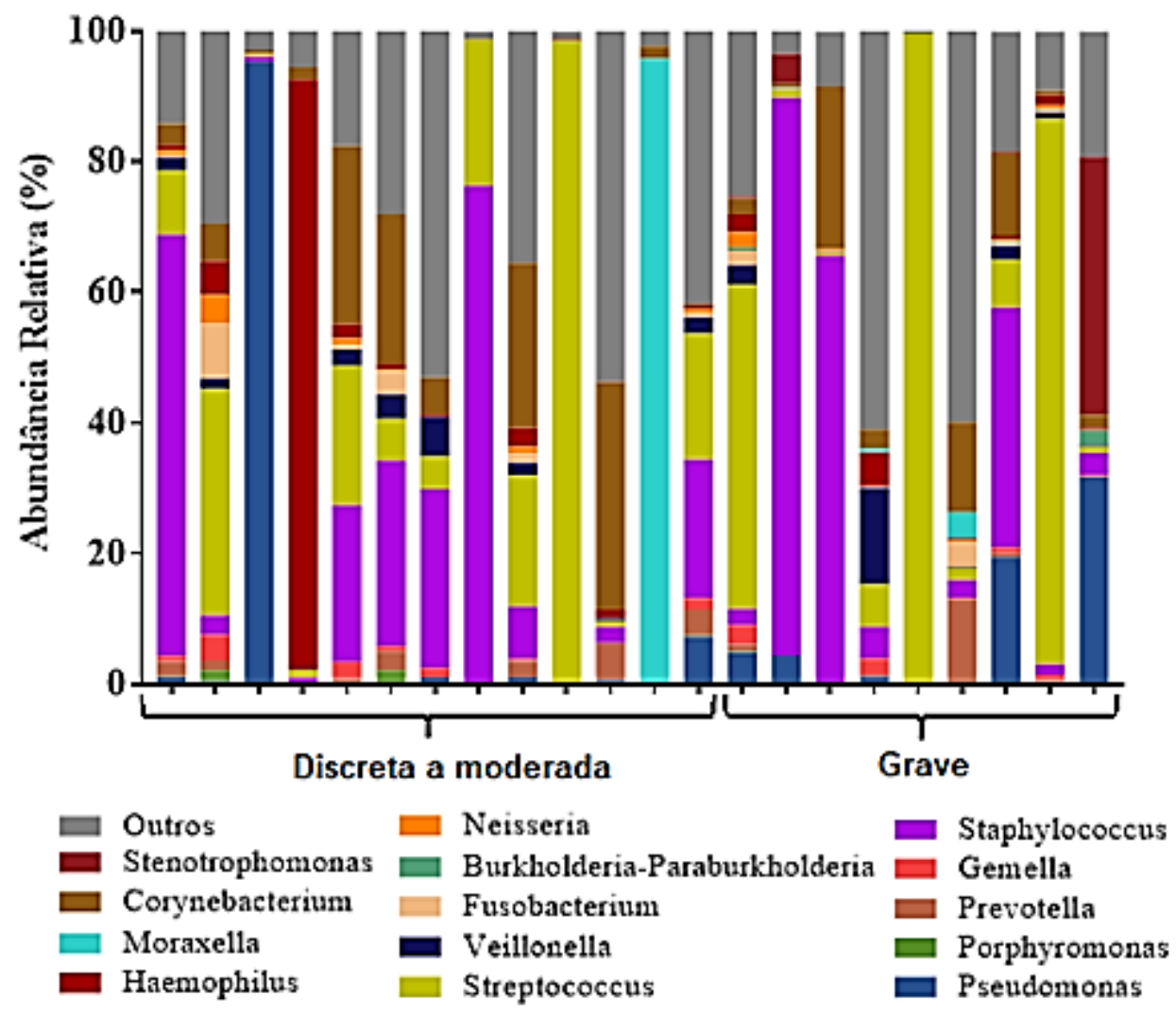

Figura 5. Principais gêneros bacterianos encontrados nas amostras de meato médio de acordo com a gravidade da doença pulmonar em cada paciente 
Os resultados da análise dos principais filos das amostras de escarro podem ser observados na Tabela 6 e na Figura 6.

Constata-se que o escarro dos pacientes no grupo com função pulmonar considerada 'Grave' apresentaram maior proporção do filo Firmicutes (16,88 x 24,40; $\mathrm{p}=0,39)$, Bacteroidetes $(9,07 \times 16,92 ; \mathrm{p}=0,18)$, Actinobacteria $(0,51 \times 1,31 ; \mathrm{p}=0,06) \mathrm{e}$ Fusobacteria $(1,80$ x 7,83; p=0,08) e menor proporção de Proteobacteria $(70,49$ x 47,76; $\mathrm{p}=0,08$ ) em comparação com o grupo com gravidade da função pulmonar 'Discreta a moderada', porém, nenhum dos resultados apresentou significância estatística.

Tabela 6. Abundância relativa dos principais filos nas amostras de escarro de acordo com a gravidade da doença pulmonar.

\begin{tabular}{|c|c|c|c|c|}
\hline \multirow{2}{*}{ Microbiota (Filos) } & & \multicolumn{2}{|c|}{ Gravidade da doença pulmonar } & \multirow[b]{2}{*}{$p^{\mathrm{a}}$} \\
\hline & & Discreta a moderada & Grave & \\
\hline \multirow{3}{*}{ Firmicutes } & Mín.-Máx. & $0,70-58,60$ & $0,2-75,40$ & \multirow{3}{*}{0,39} \\
\hline & Média & 16,88 & 24,40 & \\
\hline & Desvio Padrão & 20,86 & 25,45 & \\
\hline \multirow{3}{*}{ Bacteroidetes } & Mín.-Máx. & $0,1-34,20$ & $0,5-64,5$ & \multirow{3}{*}{0,18} \\
\hline & Média & 9,07 & 16,92 & \\
\hline & Desvio Padrão & 10,69 & 19,39 & \\
\hline \multirow{3}{*}{ Proteobacteria } & Mín.-Máx. & $16,2-98,6$ & $2,5-98.4$ & \multirow{3}{*}{0,08} \\
\hline & Média & 70,49 & 47,76 & \\
\hline & Desvio Padrão & 30,77 & 39,33 & \\
\hline \multirow{3}{*}{ Actinobacteria } & Mín.-Máx. & $0-1,9$ & $0-4,10$ & \multirow{3}{*}{0,06} \\
\hline & Média & 0,51 & 1,31 & \\
\hline & Desvio Padrão & 0,60 & 1,53 & \\
\hline \multirow{3}{*}{ Fusobacteria } & Mín.-Máx. & $0-8,30$ & $0-42,8$ & \multirow{3}{*}{0,08} \\
\hline & Média & 1,80 & 7,83 & \\
\hline & Desvio Padrão & 2,59 & 12,73 & \\
\hline
\end{tabular}

$\mathrm{p}^{\mathrm{a}}$ valor-p Modelo Linear Generalizado (GLzM) - Significante quando $p \leq 0,05$ 


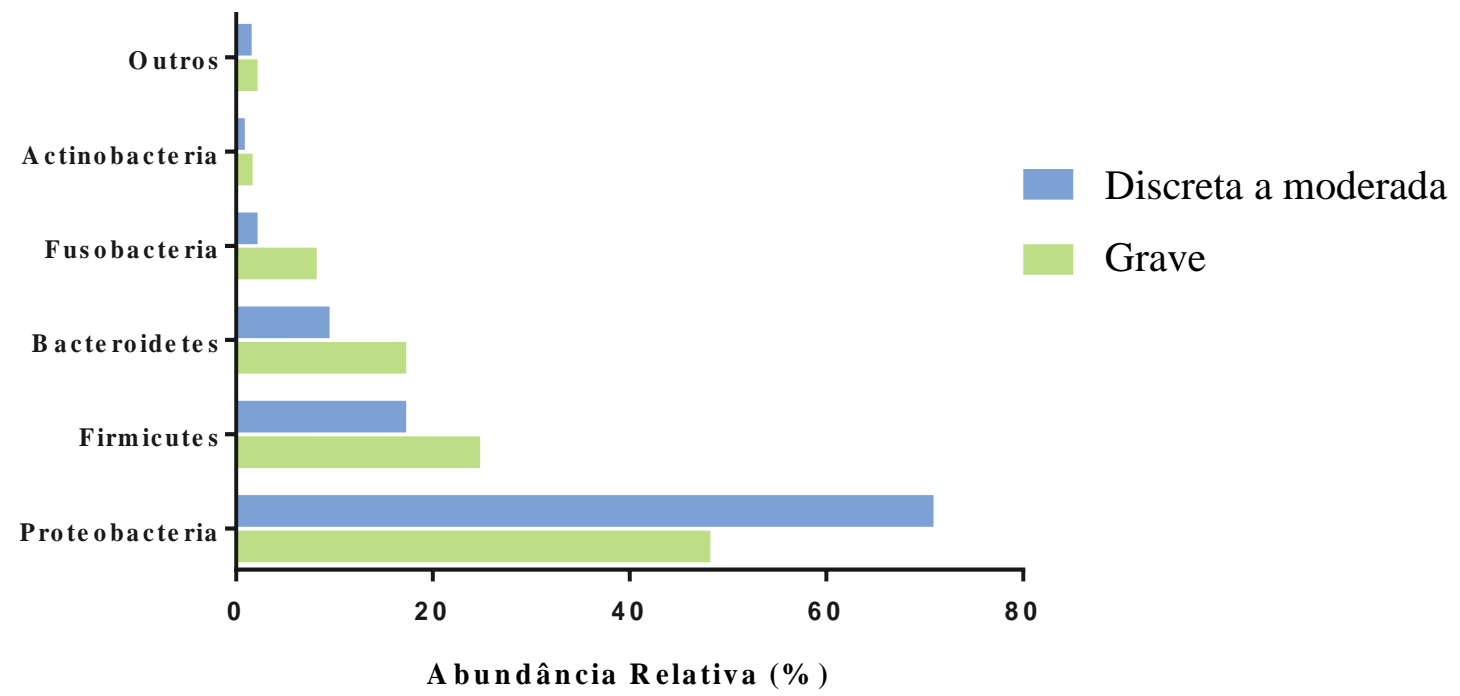

Figura 6. Filos bacterianos nas amostras de escarro de acordo com a gravidade da doença pulmonar

Os resultados da análise dos gêneros mais abundantes nas amostras de escarro podem ser observados na Tabela 7 e Figuras 7 e 8.

O escarro dos pacientes no grupo com função pulmonar considerada 'Grave' apresentou maior proporção na abundância dos gêneros Pseudomonas (33,72 x 40,90; $\mathrm{p}=0,63)$, Prevotella $(6,30 \times 12,90 ; \mathrm{p}=0,18)$, Streptococcus $(5,04 \times 7,06 ; \mathrm{p}=0,54)$ e Veillonella $(5,50 \times 10,20 ; \mathrm{p}=0,20$, enquanto que apresentaram menor proporção dos gêneros Haemophilus $(17,13$ x 2,25; p=0,05) Neisseria $(3,80$ x 2,06; p=0,26) e Burkholderia-Paraburkholderia $(14,36 \times 0,07 ; \mathrm{p}=0,12)$ em comparação com o grupo com gravidade da função pulmonar 'Discreta a moderada', em que a diferença do gênero Haemophilus foi estatisticamente significativa. $\mathrm{Na}$ análise do escarro, a comparação dos resultados das médias dos gêneros bacterianos de cada grupo (Tabela 7) foi semelhante ao perfil encontrado na análise individual (Figura 8), com aumento de abundância de Pseudomonas nos pacientes com função pulmonar grave, bem como aumento nas abundâncias relativas de Prevotella, Veillonella e Fusobacterium. 
Tabela 7. Abundância relativa dos principais gêneros nas amostras de escarro de acordo com a gravidade da doença pulmonar.

\begin{tabular}{|c|c|c|c|c|}
\hline \multirow{2}{*}{ Microbiota (Gêneros) } & & \multicolumn{2}{|c|}{ Gravidade da doença pulmonar } & \multirow{2}{*}{$p^{\mathbf{a}}$} \\
\hline & & Discreta a moderada & Grave & \\
\hline \multirow{3}{*}{ Pseudomonas } & Mín.-Máx. & $0-96,7$ & $0-98,2$ & \multirow{3}{*}{0,63} \\
\hline & Média & 33,72 & 40,90 & \\
\hline & Desvio Padrão & 39,21 & 42,06 & \\
\hline \multirow{3}{*}{ Porphyromonas } & Mín.-Máx. & $0-2,0$ & $0-11,10$ & \multirow{3}{*}{0,31} \\
\hline & Média & 1,03 & 2,13 & \\
\hline & Desvio Padrão & 1,87 & 3,60 & \\
\hline \multirow{3}{*}{ Prevotella } & Mín.-Máx. & $0,1-20,4$ & $0,5-62,6$ & \multirow{3}{*}{0,18} \\
\hline & Média & 6,30 & 12,9 & \\
\hline & Desvio Padrão & 7,17 & 17,12 & \\
\hline \multirow{3}{*}{ Gemella } & Mín.-Máx. & $0-4,70$ & $0-5,90$ & \multirow{3}{*}{0,20} \\
\hline & Média & 0,72 & 1,51 & \\
\hline & Desvio Padrão & 1,29 & 1,96 & \\
\hline \multirow{3}{*}{ Staphylococcus } & Mín.-Máx. & $0-26,10$ & $0-24,20$ & \multirow{3}{*}{0,85} \\
\hline & Média & 3,60 & 3,10 & \\
\hline & Desvio Padrão & 7,46 & 6,80 & \\
\hline \multirow{3}{*}{ Streptococcus } & Mín.-Máx. & $0,1-31,0$ & $0-28,8$ & \multirow{3}{*}{0,54} \\
\hline & Média & 5,04 & 7,06 & \\
\hline & Desvio Padrão & 8,57 & 9,15 & \\
\hline \multirow{3}{*}{ Veillonella } & Mín.-Máx. & $0,1-16,40$ & $0-41,2$ & \multirow{3}{*}{0,20} \\
\hline & Média & 5,50 & 10,2 & \\
\hline & Desvio Padrão & 5,86 & 12,57 & \\
\hline \multirow{3}{*}{ Fusobacterium } & Mín.-Máx. & $0-7,30$ & $0-42,7$ & \multirow{3}{*}{0,10} \\
\hline & Média & 1,4 & 7,06 & \\
\hline & Desvio Padrão & 2,24 & 12,87 & \\
\hline \multirow{3}{*}{$\begin{array}{l}\text { Burkholderia - } \\
\text { Paraburkholderia }\end{array}$} & Mín.-Máx. & $0-94,0$ & $0-1,0$ & \multirow{3}{*}{0,12} \\
\hline & Média & 14,36 & 0,07 & \\
\hline & Desvio Padrão & 34,92 & 0,27 & \\
\hline \multirow{3}{*}{ Neisseria } & Mín.-Máx. & $0-13,60$ & $0-9,50$ & \multirow{3}{*}{0,26} \\
\hline & Média & 3,80 & 2,06 & \\
\hline & Desvio Padrão & 4,98 & 3,07 & \\
\hline \multirow{3}{*}{ Haemophilus } & Mín.-Máx. & $0,1-95,8$ & $0,1-8,20$ & \multirow{3}{*}{$0,050^{*}$} \\
\hline & Média & 17,13 & 2,25 & \\
\hline & Desvio Padrão & 28,37 & 2,49 & \\
\hline & Mín.-Máx. & $0-0$ & $0-0,1$ & \\
\hline Moraxella & Média & 0 & 0,01 & 0,12 \\
\hline & Desvio Padrão & 0 & 0,03 & \\
\hline & Mín.-Máx. & $0-0,1$ & $0-0,1$ & \\
\hline Corynebacterium & Média & 0,01 & 0,007 & 0,53 \\
\hline & Desvio Padrão & 0,03 & 0,02 & \\
\hline & Mín.-Máx. & $0-0$ & $0-10,60$ & \\
\hline Stenotrophomonas & Média & 0 & 0,86 & 0,26 \\
\hline & Desvio Padrão & 0 & 2,92 & \\
\hline
\end{tabular}

$\mathrm{p}^{\mathrm{a}}$ valor-p Modelo Linear Generalizado (GLzM) - Significante quando $p \leq 0,05$; *Significância confirmada com pós-teste de Sidak 


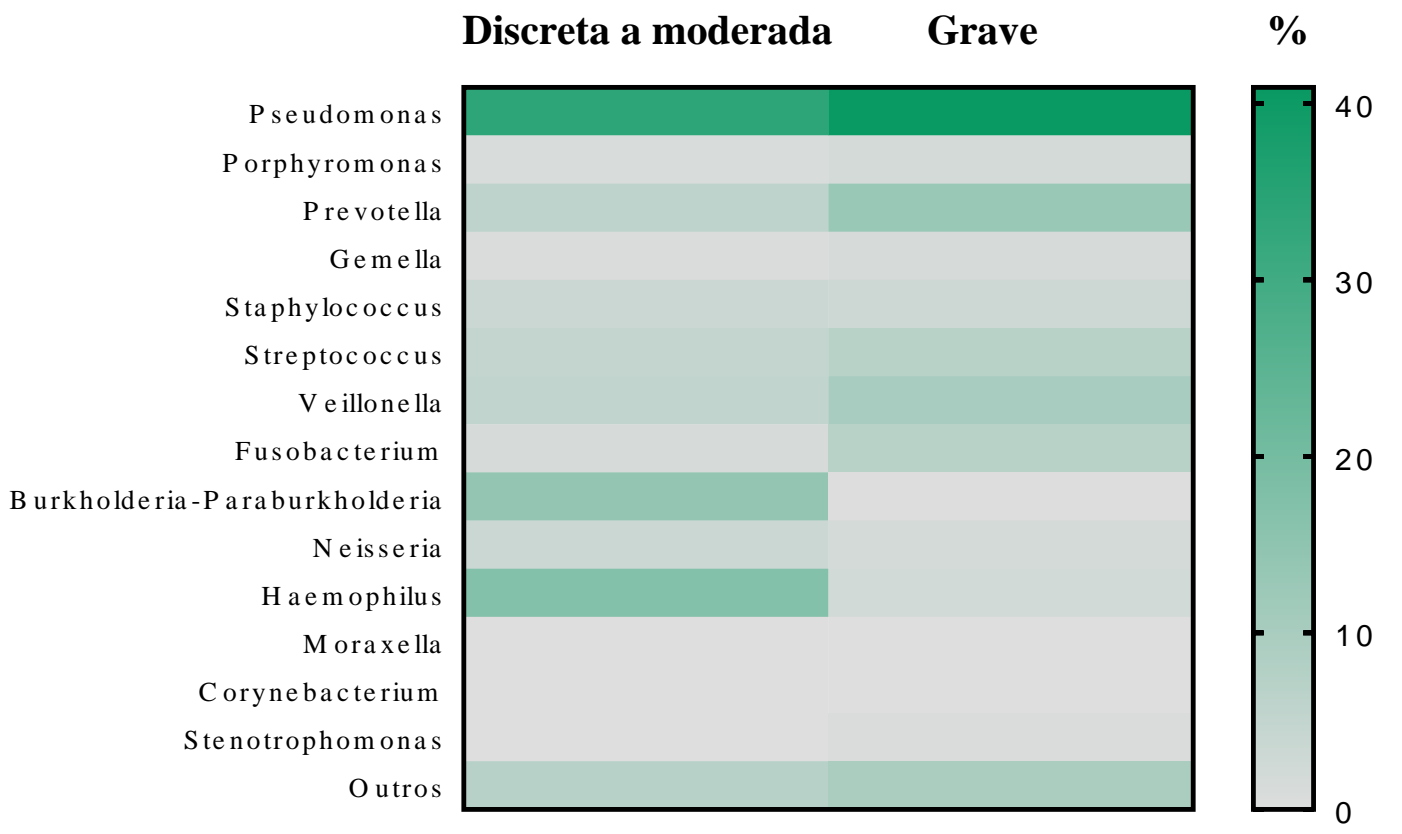

Figura 7. Gêneros bacterianos nas amostras de escarro de acordo com a gravidade da doença pulmonar

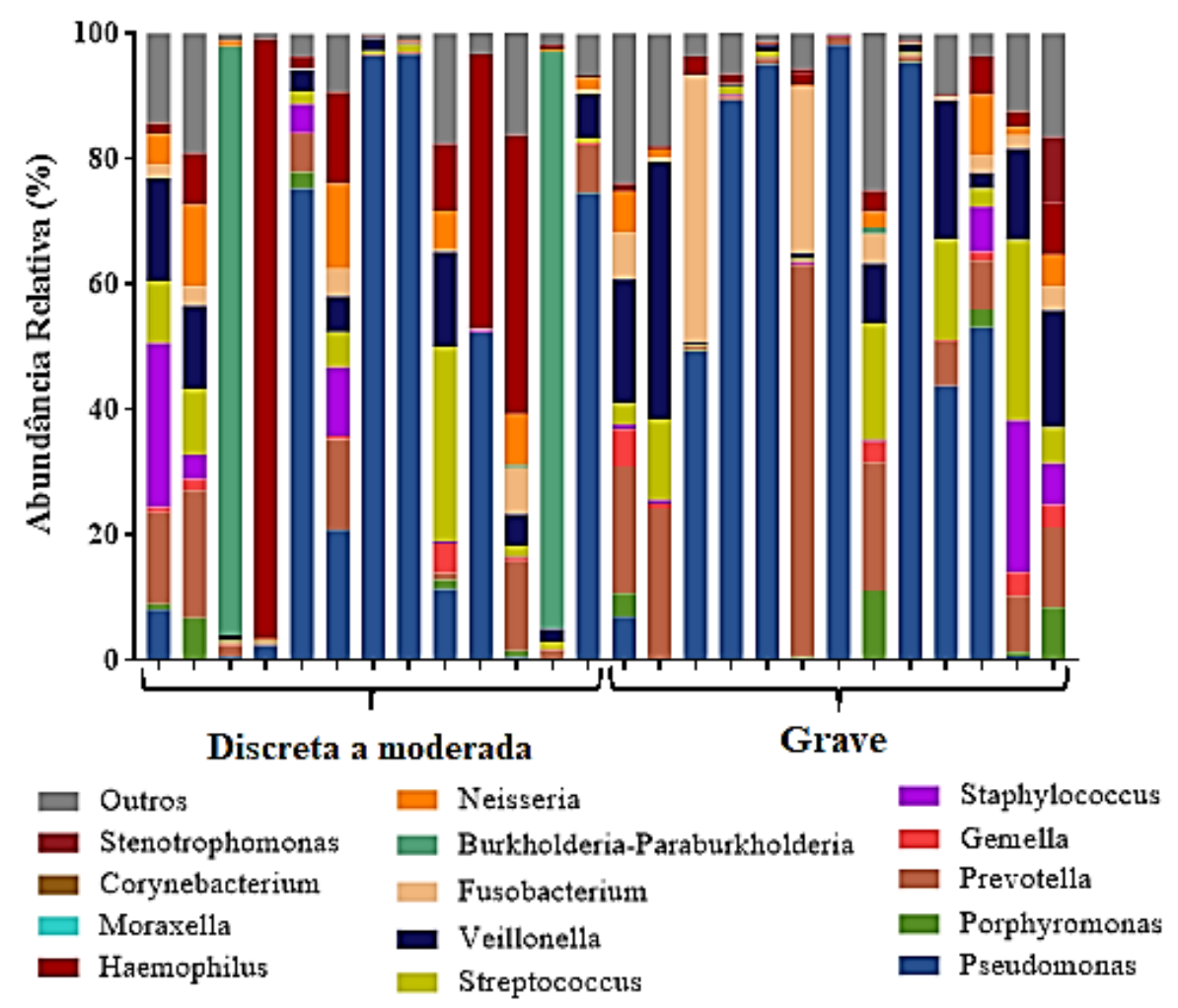

Figura 8. Principais gêneros bacterianos encontrados nas amostras de escarro de acordo com a gravidade da doença pulmonar em cada paciente 
Foram comparados os resultados de abundância relativa dos gêneros bacterianos entre as amostras pareadas de cada paciente, de acordo com a função pulmonar (Figura 9). Pode-se observar que as amostras de meato médio e escarro dos pacientes que foram classificados com função pulmonar discreta a moderada compartilham alguns gêneros bacterianos, principalmente Streptococcus, Staphylococcus e Prevotella. Desses pacientes, apenas dois (\#3 e \#11) apresentam uma microbiota bem distinta entre os dois sítios estudados. Não foram encontrados dados clínicos que pudessem ser relacionados com esses achados.

Nas amostras dos pacientes com função pulmonar grave, constatou-se o contrário. Os pacientes apresentam um perfil bem distinto de abundância relativa quando comparados os dois sítios estudados, com maior prevalência de Staphylococcus nas amostras de meato médio e Pseudomonas nas amostras de escarro. Nesse caso, apenas um paciente (\#32) possuía uma similaridade relativa nos perfis de microbioma entre as amostras. Nas informações clínicas, esse paciente apesentou scores de SNOT 20 e NOSE mais elevados, além pontuação mais baixa do quesito respiratório do CFQ-R, entre o grupo com função pulmonar grave, ou seja, era o mais sintomático do ponto de vista nasossinusal e apresentava pior score no domínio relacionado ao sistema respiratório avaliado no questionário de qualidade de vida. 


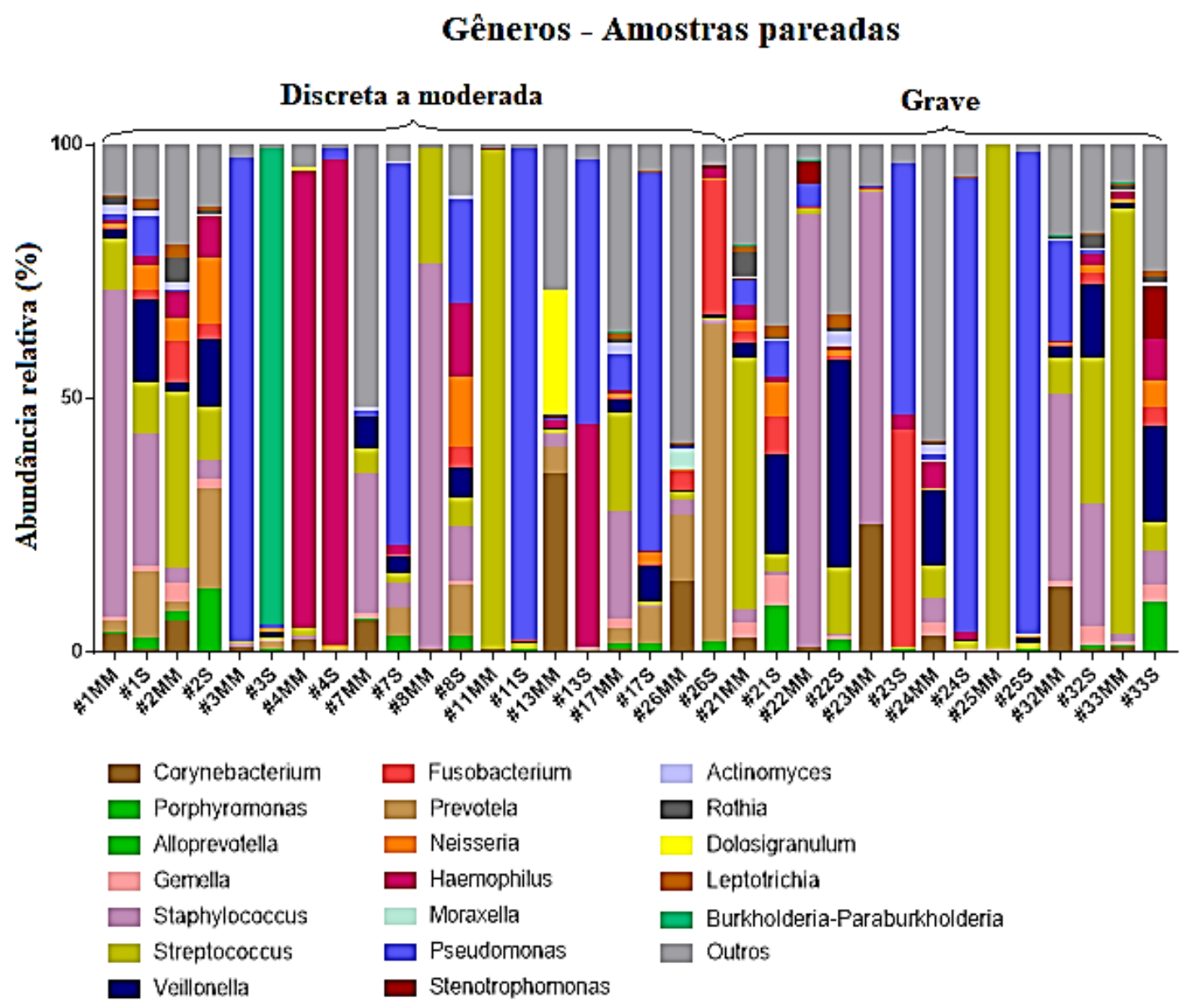

Figura 9. Principais gêneros bacterianos observados nas amostras de meato médio e escarro dos pacientes com função pulmonar discreta/moderada e grave. (\#número de identificação de cada paciente; MM: Amostras de meato médio; S: amostras de escarro)

5.2.2 Análise das diversidades (alfa e beta diversidade)

\subsubsection{Alfa Diversidade - Índices de Shannon, Simpson e Chaol}

A diversidade (índice de Shannon e Simpson) e riqueza (estimativa de riqueza de Chao1) foram observadas nas amostras de meato médio e escarro de acordo com a gravidade da função pulmonar, dividida entre discreta à moderada (VEF1 $\geq 50 \%$ ) e grave (VEF1 $\leq 40 \%$ ). Os resultados da alfa diversidade das amostras de meato médio podem ser observados na Tabela 8 e Figura 10.

O meato médio dos pacientes no grupo com doença pulmonar considerada grave apresentaram valores mais elevados nos índices de Shannon, Simpson e Chao1, ou seja, apresentaram maior diversidade e riqueza em comparação com o grupo com doença 
pulmonar discreta à moderada, porém, nenhum dos resultados apresentou significância estatística.

Tabela 8. Alfa diversidade de acordo com a gravidade da doença pulmonar nas amostras de meato médio.

\begin{tabular}{lc|c|c|c}
\hline \multirow{2}{*}{ Microbiota } & \multirow{2}{*}{ Meato médio } & \multicolumn{2}{|c|}{ Diversidade } & Riqueza \\
\cline { 3 - 5 } & \multicolumn{1}{|l}{$\begin{array}{c}\text { Índice de } \\
\text { Shannon }\end{array}$} & $\begin{array}{c}\text { Índice de } \\
\text { Simpson }\end{array}$ & Chao1 \\
\hline \multirow{2}{*}{ Discreta à } & Mín.-Máx. & $0,76-4,65$ & $0,23-0,97$ & $124,75-2747,89$ \\
moderada & Média (Desvio Padrão) & $3,12(1,41)$ & $0,73(0,27)$ & $1063,64(851,89)$ \\
\cline { 3 - 5 } Grave & Mín.-Máx. & $1,90-4,33$ & $0,47-0,97$ & $436,53-2325,22$ \\
& Média (Desvio Padrão) & $3,27(0,90)$ & $0,79(0,18)$ & $1280,04(689,55)$ \\
\hline $\boldsymbol{p}^{\mathbf{a}}$ & & 0,81 & 0,63 & 0,54 \\
\hline
\end{tabular}

$\mathrm{p}^{\mathrm{a}}$ valor-p Modelo Linear Generalizado (GLzM) - Significante quando $p \leq 0,05$
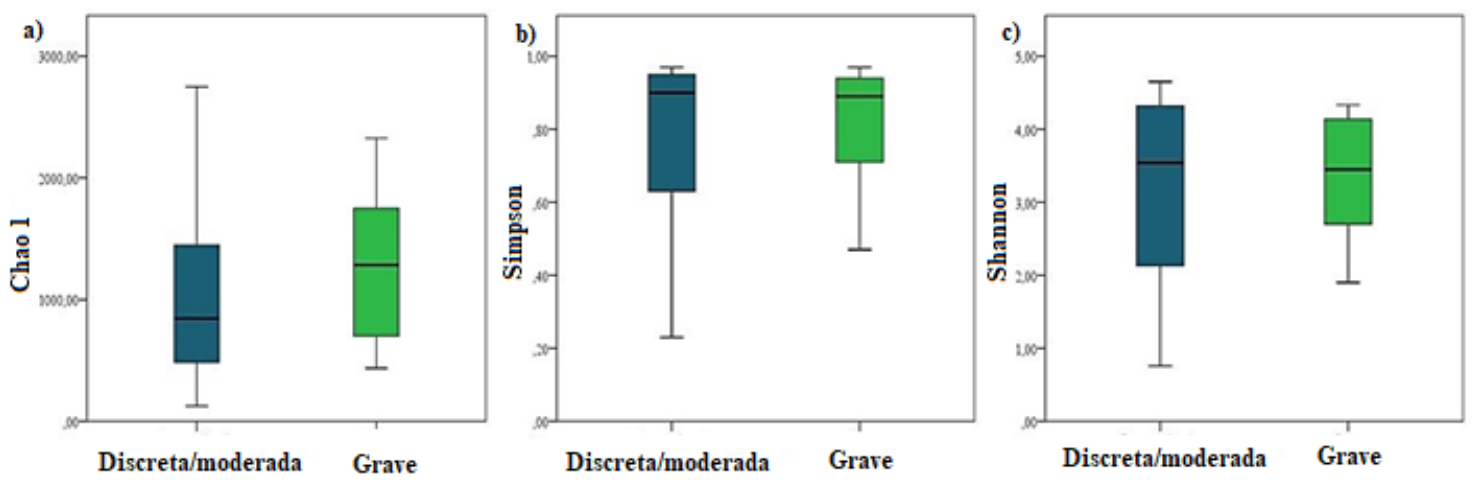

Figura 10. Alfa diversidade nas amostras de meato médio de acordo com a gravidade da doença pulmonar (azul: discreta a moderada; verde: grave): a) índices de Chao1, b) Simpson e c) Shannon

Os resultados dos índices de alfa diversidade das amostras de escarro podem ser observados na Tabela 9 e Figura 11.

O escarro dos pacientes no grupo com função pulmonar considerada grave apresentou valores mais elevados nos índices de Shannon, Simpson e Chao1 em 
comparação com o grupo com gravidade da função pulmonar discreta a moderada, porém nenhum dos resultados apresentou significância estatística.

Tabela 9. Alfa diversidade de acordo com a gravidade da doença pulmonar nas amostras de escarro.

\begin{tabular}{|c|c|c|c|c|}
\hline \multirow{2}{*}{\multicolumn{2}{|c|}{ Microbiota - Escarro }} & \multicolumn{2}{|c|}{ Diversidade } & \multirow{2}{*}{$\begin{array}{c}\text { Riqueza } \\
\text { Chao1 } \\
\end{array}$} \\
\hline & & $\begin{array}{l}\text { Índice de } \\
\text { Shannon }\end{array}$ & $\begin{array}{c}\text { Índice de } \\
\text { Simpson }\end{array}$ & \\
\hline Discreta a & Mín.-Máx. & $1,23-5,13$ & $0,32-0,97$ & $696,8-3588$ \\
\hline moderada & Média (Desvio Padrão) & $3,24(1,16)$ & $0,76(0,19)$ & $2060(850,7)$ \\
\hline \multirow[t]{2}{*}{ Grave } & Mín.-Máx. & $2,60-5,31$ & $0,67-0,98$ & $1197-6381$ \\
\hline & Média (Desvio Padrão) & $3,70(0,92)$ & $0,85(0,11)$ & $2595(1454)$ \\
\hline$p^{\text {a }}$ & & 0,27 & 0,14 & 0,19 \\
\hline
\end{tabular}

$\mathrm{p}^{\mathrm{a}}$ valor $-\mathrm{p}$ Modelo Linear Generalizado $(\mathrm{GLzM})-$ Significante quando $p \leq 0,05$
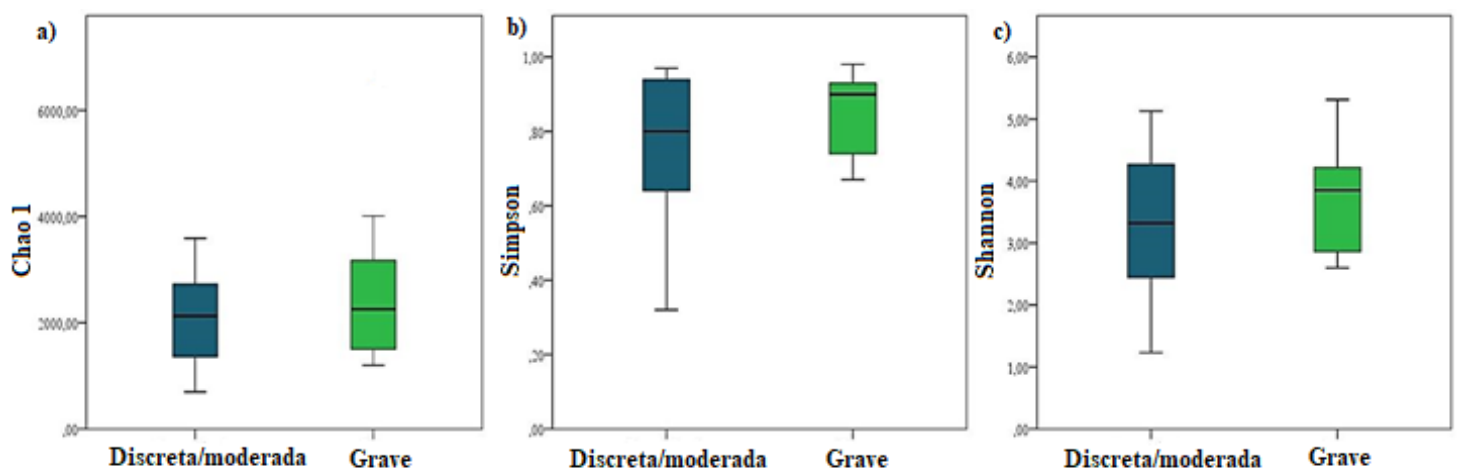

Figura 11. Alfa diversidade nas amostras de escarro de acordo com a gravidade da doença pulmonar (azul: discreta a moderada; verde: grave): a) índices de Chao1, b) Simpson e c) Shannon

\subsubsection{Beta diversidade - ponderada (Weighted) e não ponderada (Unweighted)}

Para observar as diferenças com relação à beta diversidade, foi construído o gráfico de análise de coordenadas principais (PCoA) baseado nas matrizes de distância Unifrac ponderada e não ponderada. Essas matrizes são formas de representar os desenhos de estrutura de comunidade, mostrando como essas comunidades se comportam em diferentes condições. As coordenadas de análise principais foram representadas pelos 
eixos 1 e 2 em cada figura, em que cada ponto representado entre os eixos indica um participante do estudo. A análise de PCoA não ponderada leva em conta a presença ou ausência de espécies na distribuição espacial das amostras, enquanto que a análise de PCoA ponderada leva em conta a quantidade de espécies observadas na distribuição especial. Deste modo, a análise ponderada permite avaliar a estrutura bacteriana referente às bactérias mais abundantes. Se há diferença entre os grupos é porque as bactérias mais abundantes estão conduzindo essa divisão. Já a análise não ponderada, representa como essa estrutura bacteriana se comporta como um todo, levando em consideração todas as bactérias presentes, independentemente de sua abundância. Costuma-se dar mais ênfase às analises ponderadas. ${ }^{(67)}$ Nas Figuras 12,13 e 14, as análises ponderadas estão à esquerda e as análises não ponderadas, à direita.

Para melhor observar as diferenças entre os grupos, foi realizada uma primeira análise por tipo de amostra, observando variáveis como gravidade da doença, uso de dornase alfa, uso de antibiótico inalatório e uso de antibiótico oral profilático. Posteriormente, foi feita uma análise de acordo com a gravidade da doença pulmonar.

Na primeira análise (Figura 12), comparou-se a distribuição espacial das amostras de escarro e meato médio de forma geral e, como esperado, houve diferença significativa entre as amostras na análise ponderada ( $\mathrm{p}<0,001, \mathrm{~F}=4,90)$ e não ponderada $(\mathrm{p}<0,001$, $\mathrm{F}=7,45)$. Não se observou diferença na gravidade da doença entre os tipos de amostra (ponderada: $\mathrm{p}=0,44, \mathrm{~F}=0,96$ e não ponderada: $\mathrm{p}=0,84, \mathrm{~F}=0,55$ ), no uso de alfa dornase (ponderada: $\mathrm{p}=0,50, \mathrm{~F}=0,91$ e não ponderada: $\mathrm{p}=0,72, \mathrm{~F}=0,66$ ) e no uso de antibiótico inalatório (ponderada: $\mathrm{p}=0,35, \mathrm{~F}=1,06$ e não ponderada: $\mathrm{p}=0,78, \mathrm{~F}=0,60$ ). Com relação ao uso de antibiótico oral profilático, observou-se diferença entre os tipos de amostra na análise ponderada $(\mathrm{p}=0,03, \mathrm{~F}=1,79)$, porém, não houve diferença estatística na análise não ponderada $(\mathrm{p}=0,32, \mathrm{~F}=1,08)$.

$\mathrm{Na}$ análise das amostras de meato médio (Figura 13), foi comparada a distribuição espacial do grupo com doença discreta à moderada com o grupo considerado grave (Figura 13a). Não houve diferença entre os perfis de comunidade bacteriana relacionada à gravidade da doença (ponderada: $\mathrm{p}=0,99, \mathrm{~F}=0,31$ e não ponderada: $\mathrm{p}=0,82, \mathrm{~F}=0,66$ ). Também não foram observadas diferenças entre os perfis de comunidade bacteriana quando avaliado o uso de alfa dornase (ponderada: $\mathrm{p}=0,24, \mathrm{~F}=1,30$ e não ponderada: $\mathrm{p}=0,43, \mathrm{~F}=0,96$ ) (Figura 13b), uso de antibiótico inalatório (ponderada: $\mathrm{p}=0,86, \mathrm{~F}=0,56 \mathrm{e}$ 
não ponderada: $\mathrm{p}=0,18, \mathrm{~F}=1,29$ ) (Figura 13c) e uso de antibiótico oral profilático (ponderada: $\mathrm{p}=0,61, \mathrm{~F}=0,81$ e não ponderada: $\mathrm{p}=0,31, \mathrm{~F}=1,02$ ) (Figura 13d).

$\mathrm{Na}$ análise das amostras de escarro (Figura 14), comparamos a distribuição espacial do grupo com doença discreta à moderada com o grupo considerado grave e observamos que não houve diferença entre os perfis de comunidade bacteriana relacionada à gravidade da doença (ponderada: $\mathrm{p}=0,28, \mathrm{~F}=1,23$ e não ponderada: $\mathrm{p}=0,92$, $\mathrm{F}=0,32$ ) (Figura 14a). O mesmo foi observado para as análises com relação ao uso de alfa dornase (ponderada: $\mathrm{p}=0,28, \mathrm{~F}=1,21$ e não ponderada: $\mathrm{p}=0,57, \mathrm{~F}=0,66$ ) (Figura $14 \mathrm{~b}$ ), uso de antibiótico inalatório (ponderada: $\mathrm{p}=0,55, \mathrm{~F}=0,79$ e não ponderada: $\mathrm{p}=0,99, \mathrm{~F}=0,17$ ) (Figura 14c) e uso de antibiótico oral profilático (ponderada: $\mathrm{p}=0,10, \mathrm{~F}=1,78$ e não ponderada: $\mathrm{p}=0,14, \mathrm{~F}=1,53$ ) (Figura $14 \mathrm{~d}$ ).

Os resultados de perfil das comunidades bacterianas, quando o sítio de coleta (escarro e meato médio) foi comparado com a gravidade da doença, foi possível verificar achados interessantes, que corroboraram com os resultados de abundância relativa, anteriormente mostrados (Figura 9). As comunidades bacterianas são distintas entre as amostras de escarro e meato médio (Figura 12a). Quando analisadas as amostras de meato médio, não foi possível distinguir os perfis de comunidade bacteriana entre os pacientes com função pulmonar discreta/moderada daqueles de pacientes com função pulmonar grave (Figura 13a). Porém, quando foi analisado o perfil das amostras de escarro, observou-se claramente que há uma distinção entre os grupos com função pulmonar discreta a moderada e grave (Figura 14a). 


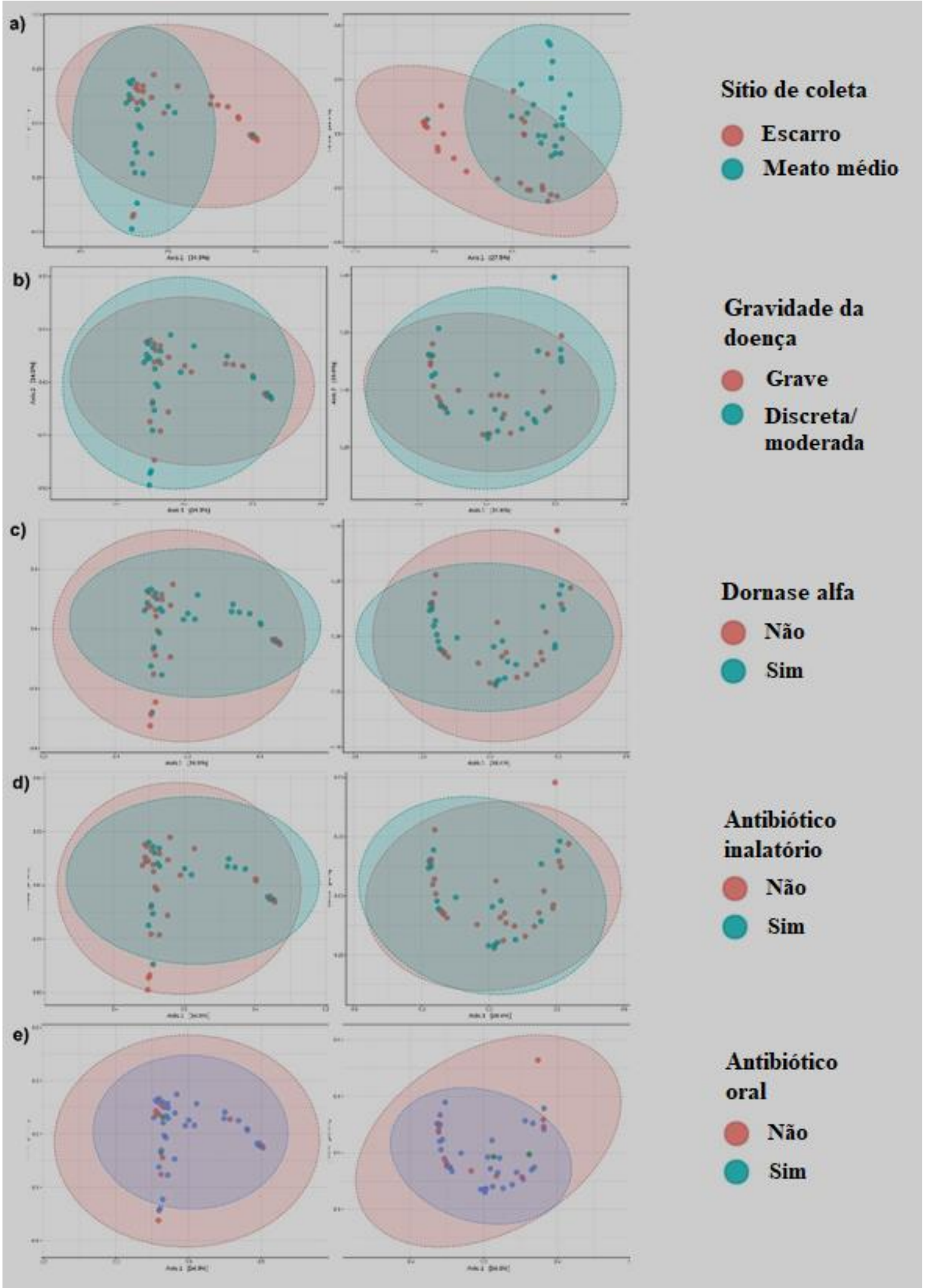

Figura 12. Análise de coordenadas principais (PCoA) entre os tipos de amostra - ponderada (esquerda) e não ponderada (direita): a) por sítio de coleta; b) por gravidade da doença; c) uso ou não de dornase alfa; d) uso ou não de antibiótico inalatório; e, e) uso ou não de antibiótico oral profilático 

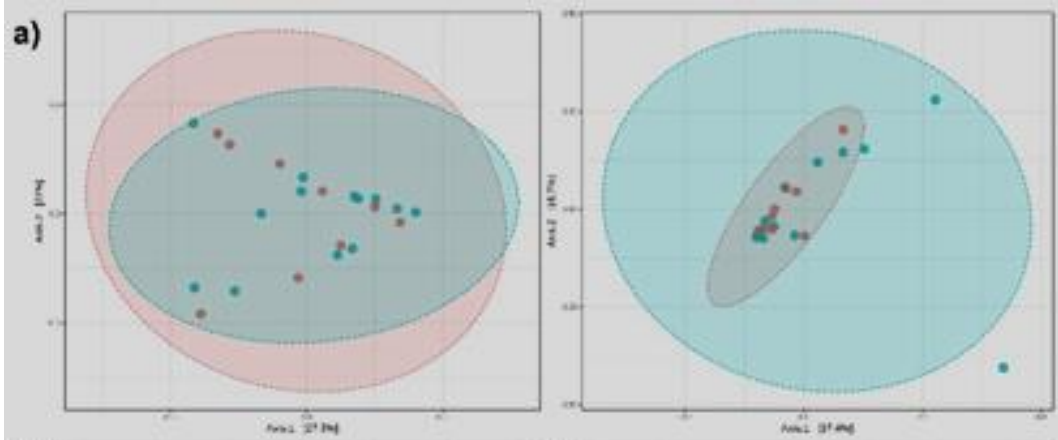

\section{Gravidade da doença}

- Grave

- Discreta/ moderada
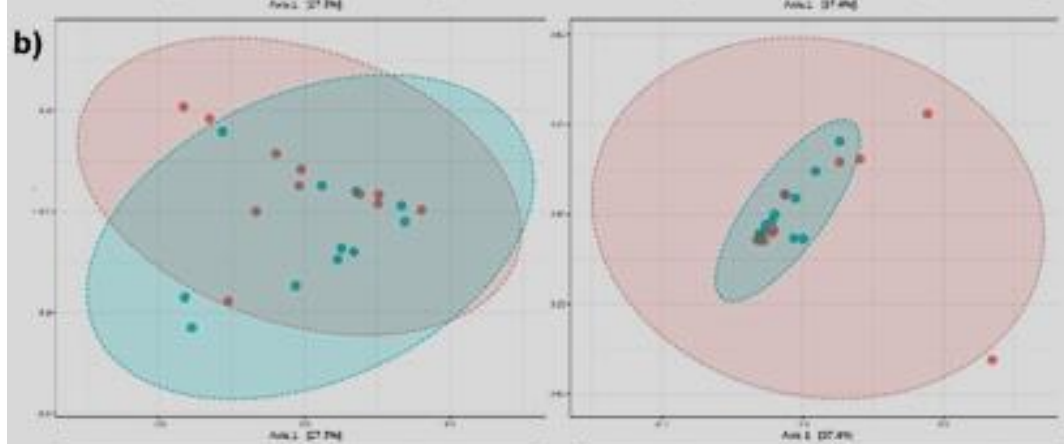

\section{Dornase alfa}

Não

Sim

c)
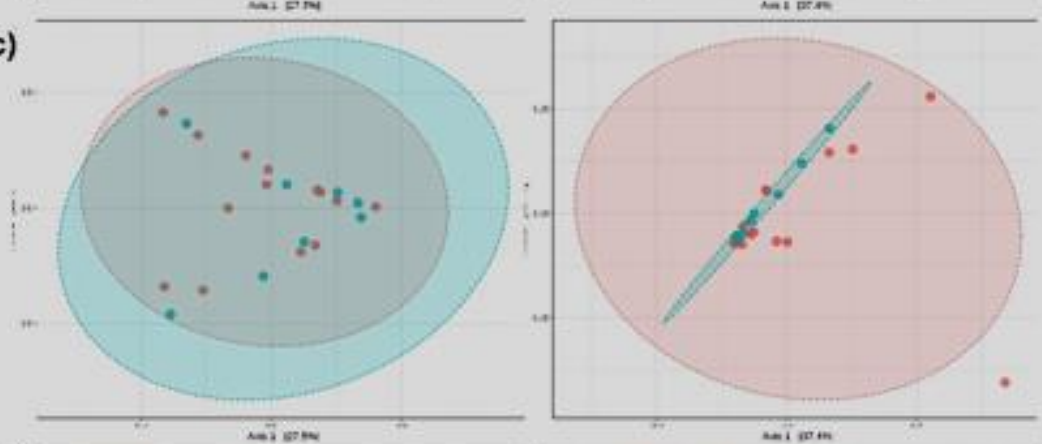

Antibiótico inalatório

Não

Sim

d)
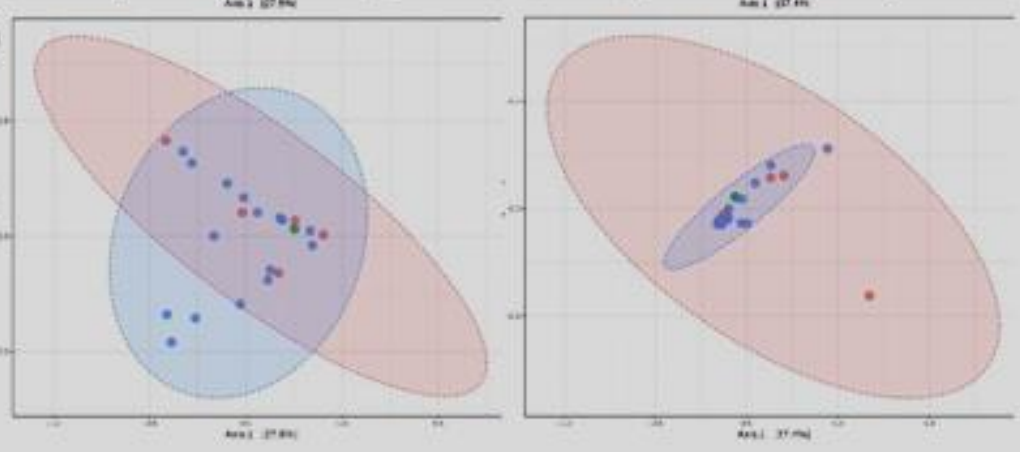

Antibiótico

oral

Não

Sim

Figura 13. Análise de coordenadas principais $(\mathrm{PCoA})$ das amostras de meato médio - ponderada (esquerda) e não ponderada (direita): a) gravidade da doença; b) uso de dornase alfa; c) uso de antibiótico inalatório; e, d) uso de antibiótico oral profilático 

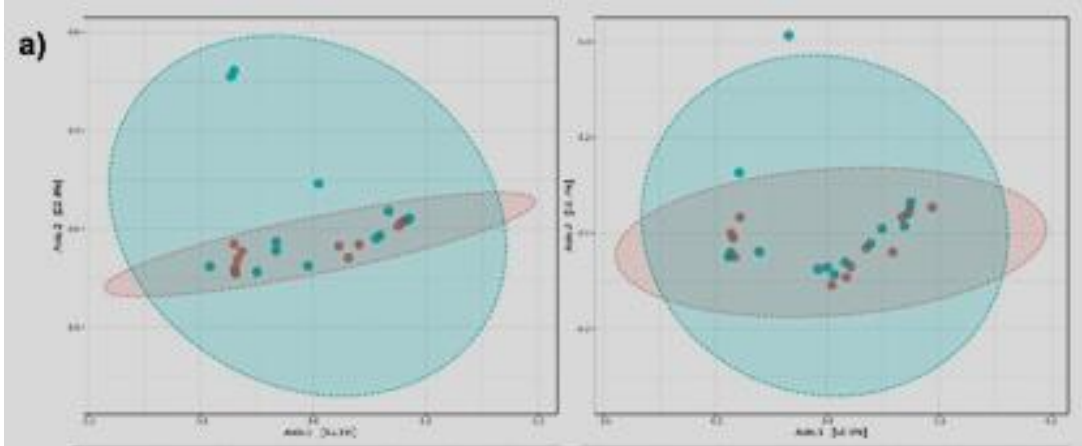

\section{Gravidade da doença}

- Grave

- Discreta/ moderada

b)
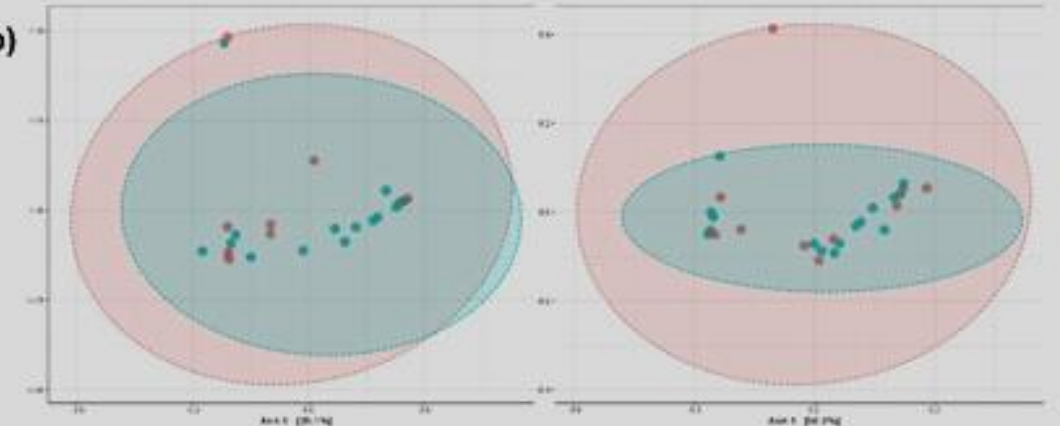

Dornase alfa

c)
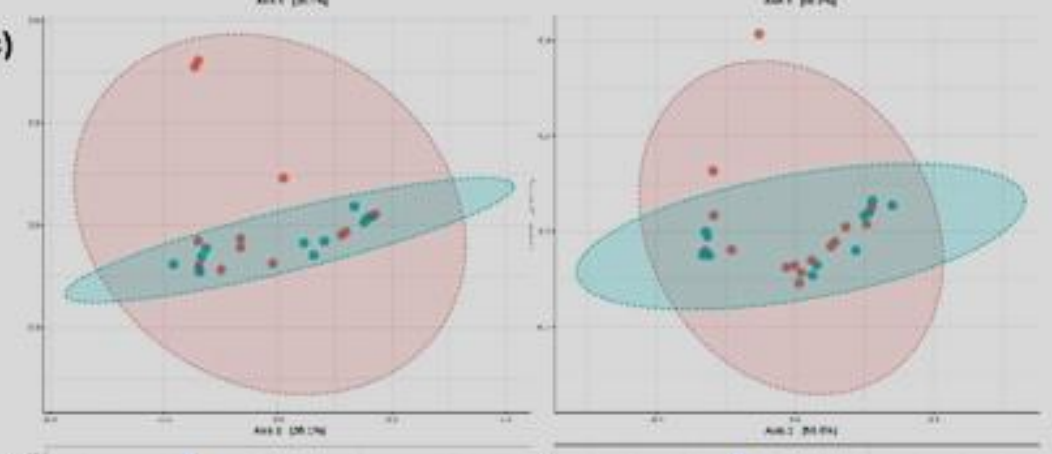

Antibiótico inalatório

d)
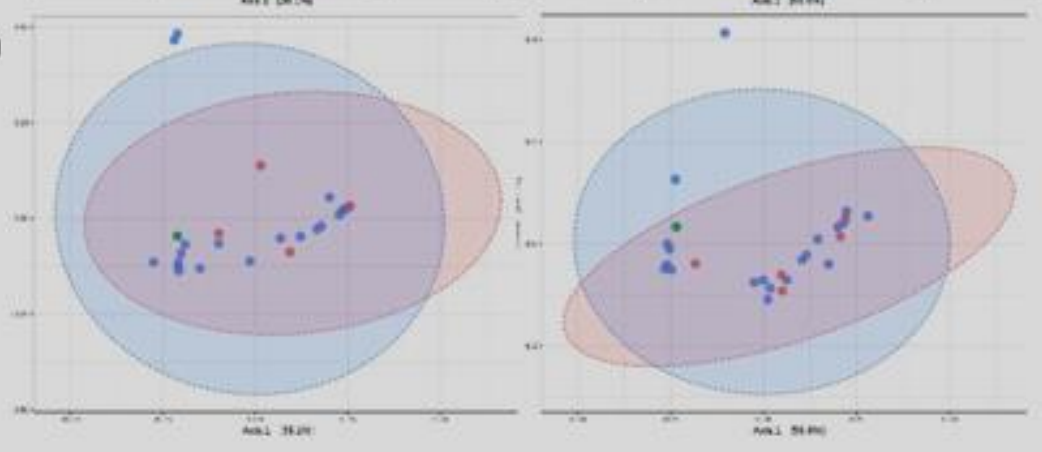

\section{Antibiótico}

oral

ก Não

Sim

Figura 14. Análise de coordenadas principais (PCoA) das amostras de escarro - ponderada (esquerda) e não ponderada (direita): a) gravidade da doença; b) uso de dornase alfa; c) uso de antibiótico inalatório; e, d) uso de antibiótico oral profilático 
6 DISCUSSÃO 


\section{DISCUSSÃO}

A utilização de métodos baseados em cultura é insuficiente para avaliar a microbiota. Eles dependem de meio adequado para promover a cultura de cada tipo de bactéria, além disso, podem selecionar microrganismos de crescimento mais rápido. A cultura está longe de representar a diversidade presente em um meio. Existe um viés relacionado com o enriquecimento do meio de cultura que favorece determinados microrganismos, que em uma competição durante o cultivo, acabam resultando na dominância de uma ou duas bactérias. ${ }^{(38)}$ Isso torna a análise da microbiota, baseada em métodos de cultura, muito simplista, sobretudo em doenças crônicas inflamatórias como a rinossinusite crônica e a fibrose cística.

A identificação de um microrganismo não representa necessariamente atividade ou patogenicidade, porquanto bactérias comensais também são amplificadas junto com as virulentas. ${ }^{(21)}$ Além disso, uma limitação potencial dos estudos moleculares baseados no DNA é a impossibilidade de diferenciar bactérias vivas e mortas. Em alguns estudos questiona-se, se essa limitação pode explicar porque não houve mudança na estrutura de comunidade bacteriana após uso de antibióticos. ${ }^{(68)}$ No entanto, a maioria dos antibióticos quebra o DNA e altera a estrutura do RNA ribossomal, impedindo a amplificação dessas bactérias inviáveis. Questiona-se, também, se a falta de mudança na composição e diversidade do microbioma durante a exacerbação e durante os períodos de estabilidade da doença, poderiam ser explicadas por mudanças nos locais de contaminação ao longo das vias aéreas ou mudança na expressão gênica dessas bactérias. ${ }^{(42)}$ Essas limitações não podem ser respondidas em estudos fundamentados apenas na identificação da comunidade por meio do $16 S$ rRNA. No entanto, é preciso conhecer a estrutura da comunidade bacteriana e suas características, antes de fazer análises mais específicas como viabilidade ou expressão gênica de determinadas bactérias.

Alguns desafios são enfrentados em estudos nos quais se propõe analisar o microbioma nasossinusal de pacientes com doenças crônicas como a fibrose cística como: o uso de medicamentos contínuos, períodos de exacerbação e as técnicas de coleta de material. $^{(28)}$ 
No presente estudo algumas medidas foram tomadas a fim de diminuir possíveis ressalvas relacionadas a esses desafios citados anteriormente. O uso de antibióticos inalatórios e orais profiláticos pelos pacientes foi discriminado na amostra, mas não pôde ser evitado, por se tratar de um estudo observacional, não sendo possível interferir no tratamento. Pacientes que usaram antibióticos orais para tratamento de qualquer tipo de infecção, até 30 dias antes da coleta, e pacientes em vigência de exacerbação foram excluídos da amostra para evitar uma possível alteração temporária na composição do microbioma. A antissepsia do vestíbulo, bem como o uso de uma sonda estéril para encapar o $s w a b$ e protegê-lo durante a inserção até o meato médio são cuidados que foram tomados para evitar a contaminação e garantir que a amostra fosse representativa do local de coleta.

O ideal seria coletar uma amostra de tecido do seio maxilar ou etmoidal, entretanto o acesso cirúrgico a esses locais limita o tamanho da amostra, além disso, seleciona casos mais sintomáticos ou mais graves da doença. Fazer uma coleta cuidadosa no meato médio é a opção mais acessível, menos invasiva e de fácil reprodutibilidade na prática clínica. ${ }^{(28)}$

Múltiplos fatores podem explicar porque os estudos mostram resultados tão variados na literatura. A região de coleta da amostra, o método de coleta (aspirado, lavado, swab, biópsia), a população estudada, a gravidade e o fenótipo da doença podem influenciar no estudo do microbioma. Além disso, os métodos de análise estatística são complexos e são usados para tentar entender desfechos clínicos e biológicos a partir de um grande volume de dados multidimensionais. Sendo assim, a análise estatística também tem papel importante na disparidade de resultados em estudos de microbiomas. ${ }^{(28)}$

As amostras de meato médio que não foram incluídas na análise, por não apresentarem qualidade ou quantidade de DNA satisfatória, pertenciam a 10 pacientes, dentre os quais seis utilizavam antibiótico inalatório; sete usavam Azitromicina 3 vezes por semana, como antibiótico oral profilático; e oito utilizavam alfa dornase. Esses medicamentos, sobretudo a alfa dornase, podem ter influenciado na não recuperação do DNA das amostras. A alfa dornase é uma enzima que cliva seletivamente o DNA presente no muco. Apesar de a metade das 22 amostras amplificadas de meato médio pertencerem a pacientes que também usavam alfa dornase. As medicações citadas, no entanto, não influenciaram na amplificação do DNA do escarro, uma vez que nenhuma amostra foi perdida. 
No presente estudo foi encontrada uma diferença significativa na composição do microbioma entre o meato médio e o escarro. Goddard et al. ${ }^{(41)}$ também observaram diferenças entre a composição do microbioma de escarro e de via aérea superior, apesar de terem usado swab de orofaringe em vez de swab de meato médio. Os resultados entre ambos estudos foram semelhantes.

Ao avaliar os filos encontrados no escarro, observou-se o predomínio de Proteobateria, Firmicutes e Bacteroidetes e uma abundância relativa mínima de Actinobacteria. Já em um estudo feito na Universidade da Califórnia ${ }^{(40)}$ o predomínio foi dos filos Actinobacteria, Bacteroidetes, Firmicutes e Proteobacteria.

Os filos mais abundantes encontrados no meato médio dos pacientes foram Firmicutes $(51,47 \%)$, Proteobacteria $(28,40 \%)$ e Actinobacteria (13,10\%). Dados semelhantes foram constatados em um estudo com pacientes saudáveis ${ }^{(33)}$, em que esses mesmos filos foram encontrados em $100 \%$ dos indivíduos com abundância relativa de $48,1 \%, 25,2 \%$ e $23,2 \%$, respectivamente.

Um antagonismo potencial entre os filos Firmicutes e Actinobacteria foi proposto por Lemon et al. ${ }^{(32)}$ ao avaliar o microbioma nasal de indivíduos normais. No presente estudo, no meato médio, não foi observado esse antagonismo, e a coexistência desses dois filos em uma mesma amostra é comum. No escarro não foi possível fazer tal avaliação, pois a abundância relativa da Actinobacteria era muito baixa $(0,9 \%)$.

No estudo de Cox et al. ${ }^{(40)}$ a P. aeruginosa e a Stenotrophomonas maltophilia eram as bactérias mais abundantes no escarro de pacientes mais velhos, enquanto o $H$. influenzae apresentou pico de abundância em pacientes mais jovens. Os resultados do presente estudo são compatíveis com os de Cox et al. ${ }^{(40)}$ Observou-se uma média da abundância relativa mais elevada para os gêneros Pseudomonas e Stenotrophomonas em pacientes com doença grave, que embora não tenha sido estatisticamente significativa, houve uma tendência à diferença, especialmente quando se avaliou individualmente cada amostra. O Haemophilus apresentou abundância relativa média mais elevada no grupo de pacientes com doença discreta a moderada, com diferença estatisticamente significativa.

De acordo com Fodor et al. ${ }^{(42)}$ as bactérias mais prevalentes encontradas no escarro de pacientes adultos com FC foram a Pseudomonas e Burkholderia. Na casuística do presente estudo, os principais gêneros encontrados no escarro foram: Pseudomonas 
(37,32\%), Haemophilus (9,69\%), Prevotella (9,6\%), Veillonella (7,85\%) e Burkholderia $(7,22 \%)$.

A função pulmonar é influenciada negativamente pela presença de Pseudomonas como gênero dominante, segundo achados de Coburn et al. ${ }^{(43)}$ Entre os pacientes com doença pulmonar discreta a moderada aqui estudados, quatro apresentavam Pseudomonas como gênero dominante no escarro, e seis pacientes do grupo com doença grave. É possível que esses pacientes do grupo discreta a moderada, possam apresentar um declínio mais rápido da função pulmonar por causa desse padrão de microbioma, porém, isso só pode ser confirmado em estudo longitudinal.

Ao avaliar a abundância relativa dos gêneros encontrados no meato médio, observou-se que cinco pacientes do grupo com doença pulmonar grave apresentaram contaminação concomitante com Staphylococcus e Pseudomonas, ao passo que quase não foram encontradas Pseudomonas nos pacientes com doença discreta a moderada, a não ser em um único paciente que exibiu abundância relativa maior que $90 \%$ de Pseudomonas. O achado da coexistência dessas duas bactérias dentro de uma mesma amostra no grupo de função pulmonar grave é compatível com dados da literatura ${ }^{(17)}$ que descrevem a associação dessas duas bactérias relacionada ao declínio da função pulmonar.

Apesar de, no meato médio, ter sido encontrada uma diversidade alfa com uma média maior nos pacientes com doença grave, a diferença interindividual é maior no grupo discreta a moderada como pode ser observado na Figura 9, e nos resultados do índice de Shannon. Talvez se tivesse sido considerado um 'n' amostral maior, poder-seia confirmar dados da literatura que apontam para uma diversidade menor relacionada com uma função pulmonar pior. ${ }^{(13,42,43,45)}$ Assim como Paganin et al. ${ }^{(11)}$, que estudaram microbioma de escarro de 78 pacientes, no presente estudo, também, não foi encontrada diferença estatisticamente significativa no escarro de pacientes, quando divididos por gravidade da função pulmonar, mesmo com uma amostra menor que 31 pacientes.

A composição do microbioma do escarro e meato médio, embora tenha sido diferente na população estudada, mostrou a existência de alguns gêneros que colonizaram ambos os sítios avaliados, inclusive bactérias patogênicas, como a Pseudomonas, Staphylococcus, Prevotella, Fusobacterium e Haemophilus, o que pode indicar que o 
meato médio é um possível reservatório desses patógenos, como sugerem vários outros estudos. $^{(4,6,13-16,30,46,47)}$. Porém, esse é um dado questionável, quando se compara os resultados referentes ao meato médio com os do escarro, considerando a gravidade da doença pulmonar. Pôde-se observar que as amostras de meato médio e escarro dos pacientes, que foram classificados com doença pulmonar discreta a moderada, compartilham alguns gêneros bacterianos, sobretudo Streptococcus, Staphylococcus e Prevotella. Nas amostras coletadas de pacientes com doença pulmonar grave, no entanto, foi observado que apresentaram um perfil bem distinto de abundância relativa, quando comparados os dois sítios estudados. Essas informações são corroboradas mediante análise de comunidade bacteriana, PCoA, na qual se observou uma diferença entre as comunidades bacterianas no escarro relacionadas com a função pulmonar, todavia, essa diferença não foi observada na avaliação do meato médio.

Esses achados sugerem que o meato médio pode ser um reservatório de patógenos para o pulmão apenas nos pacientes com função pulmonar discreta a moderada. Dados publicados na literatura mostram que existe uma suspeita de que o meato médio é fonte de infecção pulmonar, todavia, não há distinção entre os níveis de gravidade da doença pulmonar nos estudos existentes. ${ }^{(4,6,13-16,30,46,47)}$

Os pacientes com função pulmonar grave não compartilham a mesma estrutura e abundância bacteriana nos sítios estudados, ou seja, a colonização pulmonar não se relaciona com o microbioma do meato médio. O agravamento da função pulmonar está relacionado com o aumento da resposta inflamatória, migração de células polimorfonucleares e secreção de proteases, associadas ao dano tissular provocado pela infecção bacteriana nos pacientes com FC ${ }^{(6)}$. Nesse contexto, as cepas patogênicas como Pseudomonas podem ficar retidas no espessamento de muco da mucosa pulmonar com diminuição do acesso de antibióticos administrados por via oral ou inalatória.

Os achados de Mika et al. ${ }^{(44)}$, mostram que uma disbiose do microbioma de vias aéreas pode ser observada já no segundo mês de vida dos pacientes com FC. O microbioma pode promover ou manter uma inflamação previamente induzida pela falha na integridade da mucosa ou na imunidade local. Não está claro se a inflamação crônica muda a composição da microbiota, ou a alteração da microbiota com o supercrescimento de determinadas espécies afeta a abundância de outras espécies e, então, promove a inflamação, ou os dois fenômenos ocorrem simultaneamente. ${ }^{(28)}$ 
Com os dados obtidos no presente trabalho, não é possível correlacionar o agravamento da função pulmonar com o microbioma. Para tanto, seria necessário o acompanhamento do grupo com função pulmonar discreta a moderada até o momento do agravamento da função pulmonar, com avaliações periódicas do microbioma e a comparação dos resultados longitudinais.

Não foi possível avaliar o papel do antibiótico inalatório na estrutura da comunidade bacteriana. As abundâncias relativas dos gêneros bacterianos não podem ser relacionadas com uso de antibiótico inalatório. $\mathrm{Na}$ análise de comunidade bacteriana, os resultados sugerem que o antibiótico oral profilático pode estar modulando a comunidade bacteriana, pois há uma tendência ao agrupamento de pacientes que usam o antibiótico diferente dos que não utilizam. Porém, esse dado não foi analisado comparando-se a classificação de função pulmonar.

As análises das comunidades bacterianas foram analisadas comparando-se os dados ponderados (weighted) com os não ponderados (unweighted) e, neste caso, não se observou diferenças. Isso acontece porque as bactérias mais abundantes, observadas nos resultados ponderados, é que estão conduzindo a estrutura dessas comunidades bacterianas. Este dado está em concordância com os da abundância, uma vez que vários pacientes apresentaram gêneros bacterianos com abundâncias relativas mais altas, mostrando a dominância dos mesmos no perfil do microbioma.

Este é o primeiro estudo brasileiro com análise do microbioma de vias aéreas em pacientes com FC. Além disso, é um estudo com avaliação de meato médio em FC com maior ' $n$ ' amostral. Estudos na área de microbiologia como este, sobretudo, os que utilizam métodos de detecção molecular, com sequenciamento de nova geração, têm grande importância na expansão dos conhecimentos em microbiologia, antes baseados em métodos dependentes da cultura, e na criação de novas hipóteses para subsidiar futuros estudos que avaliem a variação do microbioma ao longo do tempo, durante e após uma exacerbação. Desta forma, permitam vislumbrar a possibilidade de manipulação do microbioma nasossinusal, abrindo fronteiras para novas formas de tratamentos que se somem aos que apliquem antibióticos ou os substituam, facilitando a recolonização com uma microbiota comensal semelhante à de indivíduos saudáveis. 
A não padronização dos métodos independentes de cultura para identificação de microrganismos pode justificar a disparidade nos resultados encontrados nos estudos de microbioma. Não há padronização quanto o local ou método de coleta, nos protocolos de extração de DNA, nos primers de PCR utilizados, nas regiões do $16 S$ rRNA usadas no sequenciamento e na análise dos dados, o que contribui para resultados, muitas vezes, divergentes. Do mesmo modo, a falta de padronização, a necessidade de equipe especializada, o custo elevado da tecnologia e a dificuldade na interpretação dos dados ainda são empecilhos para o uso da identificação da microbiota por meio da análise da $16 S$ rRNA na prática clínica. ${ }^{(21)}$

Espera-se que, em futuro próximo, esta tecnologia seja acessível e passe a ser padrão-ouro para o diagnóstico e análise microbiana, e se torne guia para o tratamento de infecções recorrentes em pacientes com fibrose cística. ${ }^{(21)}$ 
7 CONCLUSÃO 


\section{CONCLUSÃO}

- O microbioma encontrado no meato médio dos pacientes estudados apresenta predomínio de Staphylococcus, Streptococcus, Corynebacterium e Pseudomonas e no escarro Pseudomonas, Haemophilus, Veillonella e Prevotella;

- Não houve concordância dos gêneros entre os dois sítios estudados, na análise geral;

- Ao parear as amostras dos dois sítios de cada paciente observou-se que o meato médio e o escarro têm semelhança na composição do microbioma apenas em pacientes com doença discreta a moderada. O mesmo não foi observado no grupo com doença grave;

- Não houve diferença estatisticamente significativa das médias de abundância relativa dos principais gêneros encontrados no meato médio quando se compara a gravidade da doença pulmonar. Porém, quando foi avaliada a abundância relativa de modo individual, observou-se uma prevalência maior de Pseudomonas em indivíduos com doença grave;

- No escarro, a abundância relativa de Haemophilus era maior no grupo com doença pulmonar discreta a moderada, com diferença estatisticamente significativa. Ao proceder análise individual, constatou-se um aumento de abundância relativa de Pseudomonas e Prevotella no grupo com doença pulmonar grave;

- Não houve diferença estatisticamente significativa na alfa diversidade, na riqueza, dominância ou diversidade quando se avaliou a função pulmonar em ambos os sítios de coleta. As estruturas de comunidade do escarro e do meato médio, entretanto, se mostraram diferentes e com significância estatística. na avaliação da beta diversidade.

- Os achados estão em concordância com a literatura internacional, ao apontarem a Pseudomonas como elemento importante na fisiopatologia da doença, presente tanto no escarro como no meato médio de pacientes com doença pulmonar grave. 
8 ANEXOS 
ANEXO A

NOSE

Crupo de Rinologia do Hospital das Clínicas da USP

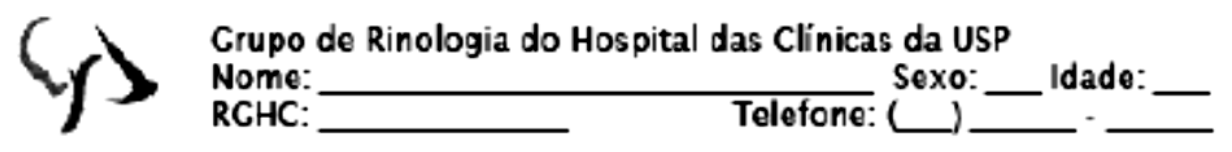

\title{
Instrumento para Avaliaçäo dos Sintomas da Obstruçảo Nasal NOSE
}

\begin{abstract}
$\rightarrow$ AO paciente: Pedimos que nos ajude a compreender melhor o impacto da obstrução nasal em sua qualidade de vida.

Por favor, dê suas respostas a esta pesquisa. Obrigado!
\end{abstract}

Durante o último més qual fol a intensidade em que as situaçöes abaixo foram urn probleme para rocé?

Faça um circulo na resposta mais correta

\begin{tabular}{|l|c|c|c|c|c|}
\cline { 2 - 6 } & $\begin{array}{c}\text { Náo é } \\
\text { um } \\
\text { problerna }\end{array}$ & $\begin{array}{c}\text { Problema } \\
\text { muito } \\
\text { pequeno }\end{array}$ & $\begin{array}{c}\text { Problema } \\
\text { moderado }\end{array}$ & $\begin{array}{c}\text { Problema } \\
\text { razoavel. } \\
\text { mente } \\
\text { grave }\end{array}$ & $\begin{array}{c}\text { Problema } \\
\text { grave }\end{array}$ \\
\hline $\begin{array}{c}\text { 1. Congestão nasal } \\
\text { ou sensação de } \\
\text { nariz cheio }\end{array}$ & 0 & 1 & 2 & 3 & 4 \\
\hline $\begin{array}{c}\text { 2. Bloquelo ou } \\
\text { obstruçato nasal }\end{array}$ & 0 & 1 & 2 & 3 & 4 \\
\hline $\begin{array}{l}\text { 3. Dificuldade para } \\
\text { respirar pelo } \\
\text { nariz }\end{array}$ & 0 & 1 & 2 & 3 & 4 \\
\hline $\begin{array}{c}\text { 4. Dificuldade para } \\
\text { dormir }\end{array}$ & 0 & 1 & 2 & 3 & 4 \\
\hline $\begin{array}{c}\text { 5. Incapaz de } \\
\text { respirar o } \\
\text { suficiente pelo } \\
\text { nariz durante } \\
\text { exercício ou } \\
\text { esforço }\end{array}$ & 0 & 1 & 2 & 3 & 4 \\
\hline
\end{tabular}

Bezerra, TFP; Padua, FGM; Pilan, RMM; Stewart, MG; Voegels, RL 


\section{ANEXO B}

SNOT 20

\section{Grupo de Rinologia do Hospital das Clínicas da USP NOME: \\ RGHC: IDADE: SEXO: \\ AvaliacÃo de RESUltados Nasossinusais. (SNOT-20)}

Você encontrará abaixo uma lista de sintomas e conseqüências sociais e emocionais da sua rinossinusite. Gostaríamos de saber mais sobre estes problemas e pedimos que respondesse às seguintes perguntas da melhor maneira possível. Não há respostas certas ou erradas e somente você pode nos dar essas informaçōes. Por gentileza, dê uma nota para seus problemas conforme se apresentaram nas duas últimas semanas. Obrigado por sua participação. Caso tenha alguma dúvida, peça a nossa ajuda imediatamente.

1. Considerando a gravidade do problema, quando aparece e a freqüência com que acontece; dê uma nota para cada item abaixo de acordo com o grau de intensidade do problema. Faça um círculo ao redor do número que corresponde ao que você sente. Use a escala ao lado:

\begin{tabular}{|c|c|c|c|c|c|c|c|}
\hline $\begin{array}{l}\text { 1. Considerando a gravidade do problema, quando } \\
\text { aparece e a frequêencia com que acontece; dê uma } \\
\text { nota para cada item abaixo de acordo com o grau } \\
\text { de intensidade do problema. Faça um círculo ao } \\
\text { redor do número que corresponde ao que você } \\
\text { sente. Use a escala ao lado: }\end{array}$ & 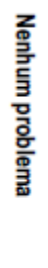 & 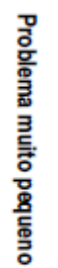 & 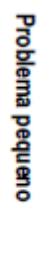 & 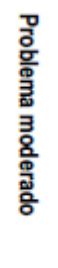 & 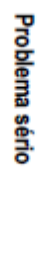 & 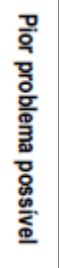 & 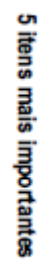 \\
\hline 1. Necessidade de assoar o nariz & 0 & 1 & 2 & 3 & 4 & 5 & $\square$ \\
\hline 2. Espirros & 0 & 1 & 2 & 3 & 4 & 5 & $\square$ \\
\hline 3. Nariz escorrendo & 0 & 1 & 2 & 3 & 4 & 5 & $\square$ \\
\hline 4. Tosse & 0 & 1 & 2 & 3 & 4 & 5 & $\square$ \\
\hline 5. Secreção nasal escorrendo para a garganta & 0 & 1 & 2 & 3 & 4 & 5 & $\square$ \\
\hline 6. Secreçao nasal grossa & 0 & 1 & 2 & 3 & 4 & 5 & $\square$ \\
\hline 7. Ouvido tampado & 0 & 1 & 2 & 3 & 4 & 5 & $\square$ \\
\hline 8. Tontura & 0 & 1 & 2 & 3 & 4 & 5 & $\square$ \\
\hline 9. Dor de Ouvido & 0 & 1 & 2 & 3 & 4 & 5 & $\square$ \\
\hline 10. Dor/ pressão na face & 0 & 1 & 2 & 3 & 4 & 5 & $\square$ \\
\hline 11. Dificuldade de pegar no sono & 0 & 1 & 2 & 3 & 4 & 5 & $\square$ \\
\hline 12. Acordar durante a noite & 0 & 1 & 2 & 3 & 4 & 5 & $\square$ \\
\hline 13. Falta de uma boa noite de sono & 0 & 1 & 2 & 3 & 4 & 5 & $\square$ \\
\hline 14. Acordar cansado & 0 & 1 & 2 & 3 & 4 & 5 & $\square$ \\
\hline 15. Fadiga & 0 & 1 & 2 & 3 & 4 & 5 & $\square$ \\
\hline 16. Produtividade diminuida & 0 & 1 & 2 & 3 & 4 & 5 & $\square$ \\
\hline 17. Concentração reduzida & 0 & 1 & 2 & 3 & 4 & 5 & $\square$ \\
\hline 18. Frustrado / Inquieto/ Irritado & 0 & 1 & 2 & 3 & 4 & 5 & $\square$ \\
\hline 19. Triste & 0 & 1 & 2 & 3 & 4 & 5 & $\square$ \\
\hline 20. Envergonhado com a doença & 0 & 1 & 2 & 3 & 4 & 5 & $\square$ \\
\hline
\end{tabular}

2. Favor marcar os itens mais importantes que estão prejudicando sua saúde (máximo de 5 itens) 


\section{ANEXO C}

CFQ-R14+

\section{Questionário de Qualidade de Vida em Fibrose Cística Revidado (pacientes acima de 14 anos)}

A compreensão do impacto que a sua doença e os seus tratamentos têm na sua vida diária pode ajudar a equipe profissional a acompanhar sua saúde e ajustar os seus tratamentos. Por isso, este questionário foi especificamente desenvolvido para pessoas portadoras de fibrose cística. Obrigado por completar o questionário.

Instruções: As questões a seguir se referem ao estado atual da sua saúde e como você a percebe. Essa informação vai permitir que a equipe de saúde entenda melhor como você se sente na sua vida diária.

Por favor, responda todas as questões. Não há respostas erradas ou certas. Se você está em dúvida quanto à resposta, escolha a que estiver mais próxima da sua situação.

\section{SESSÃO I: DEMOGRAFIA}

Por favor, complete as informações abaixo:

A) Qual a data de seu nascimento?

Dia Mês Ano

B) Qual o seu sexo?

( ) Masculino ( ) Feminino

C) Durante as últimas duas semanas você esteve de férias, faltou à escola ou ao trabalho por razões NÃO relacionadas à sua saúde?

( ) $\operatorname{Sim}$ ( ) Não

D) Qual o seu estado civil atual?

( ) 1. Solteiro(a)/nunca casou

( ) 2. Casado(a)

( ) 3. Viúvo(a)

( ) 4. Divorciado(a)

( ) 5. Separado(a)

( ) $6.2^{\circ}$ casamento

( ) 7. Juntado(a) 
E) Qual a origem dos seus familiares?
( ) 1 Branca
( ) 2 Negra
( ) 3 Mulata
( ) 4 Oriental
( ) 5 Indígena
( ) 6 Outra (qual?)
( ) 7 Prefere não responder
( ) 8 Não sabe responder

F) Qual foi o grau máximo de escolaridade que você completou?

( ) Escola Fundamental (Primário e Ginásio) Incompleto

( ) Escola Fundamental (Primário e Ginásio) Completo

( ) Escola Vocacional (Profissionalizante)

( ) Curso Médio (colegial ou científico) Incompleto

( ) Curso Médio (colegial ou científico) Completo

( ) Faculdade / Curso Superior

( ) Não frequentou a escola

G) Qual das seguintes opções descreve de melhor maneira o seu trabalho atual ou atividade escolar?

( ) Vai à escola

( ) Faz cursos em casa

( ) Procura trabalho

( ) Trabalha em período integral ou parcial (fora ou dentro de casa)

( ) Faz serviços em casa - período integral

( ) Não vai à escola ou trabalho por causa da saúde

( ) Não trabalha por outras razões

\section{SEÇÃO II. QUALIDADE DE VIDA}

Por favor, assinale o quadrado, indicando a sua resposta.

Durante as últimas duas semanas em que nível você teve dificuldade para:

\begin{tabular}{|l|l|l|l|l|l|}
\hline & \multicolumn{1}{|l|}{$\begin{array}{l}\text { Muita } \\
\text { Dificuldade }\end{array}$} & $\begin{array}{l}\text { Alguma } \\
\text { dificuldade }\end{array}$ & $\begin{array}{l}\text { Pouca } \\
\text { dificuldade }\end{array}$ & $\begin{array}{l}\text { Nenhuma } \\
\text { dificuldade }\end{array}$ \\
\hline \begin{tabular}{l|l|l|l|l|} 
1. Realizar atividades vigorosas \\
como correr ou praticar esportes
\end{tabular} & & & & & \\
\hline $\begin{array}{l}\text { 2. Andar tão depressa quanto os } \\
\text { outros }\end{array}$ & & & & & \\
\hline $\begin{array}{l}\text { 3. Carregar ou levantar coisas } \\
\text { pesadas como livros, pacotes ou } \\
\text { mochilas }\end{array}$ & & & & & \\
\hline $\begin{array}{l}\text { 4. Subir um lance de escadas } \\
\text { S. Subir tão depressa quanto os } \\
\text { outros }\end{array}$ & & & & & \\
\hline
\end{tabular}


Por favor, assinale o quadrado, indicando sua resposta.

Durante as últimas duas semanas indique quantas vezes:

\begin{tabular}{|l|l|l|l|}
\hline & Sempre Frequentemente Às vezes & Nunca \\
\hline 6. Você se sentiu bem & & & \\
\hline 7. Você se sentiu preocupado(a)
\end{tabular}

Por favor, circule o número que indica a sua resposta. Escolha apenas uma resposta para cada questão.

Pensando sobre o seu estado de saúde nas últimas duas semanas:

13. Qual é a sua dificuldade para andar?

( ) 1. Você consegue andar por longo período, sem se cansar.

( ) 2. Você consegue andar por longo período, mas se cansa.

( ) 3. Você não consegue andar por longo período porque se cansa rapidamente

( ) 4. Você evita de andar, sempre que é possível, porque é muito cansativo.

14. Como você se sente com relação à comida?

( ) 1. Só de pensar em comida, você se sente mal.

( ) 2. Você às vezes gosta de comer

( ) 4. Você sempre gosta de comer

15. Até que ponto os tratamentos que você faz tornam a sua vida diária difícil?
( ) 1. Nem um pouco
( ) 2. Um pouco
( ) 3. Moderadamente
( ) 4. Muito

16. Quanto tempo você gasta nos tratamentos diariamente?
( ) 1. Muito tempo
( ) 2. Algum tempo
( ) 3. Pouco tempo
( ) 4. Não muito tempo 
17. O quanto é difícil para você realizar seus tratamentos, inclusive medicações, diariamente?

( ) 1. Não é difícil

( ) 2. Um pouco difícil

( ) 3. Moderadamente difícil

( ) 4. Muito difícil

18. O que você pensa da sua saúde no momento?
( ) 1. Excelente
( ) 2. Boa
( ) 3. Mais ou menos (regular)
( ) 4. Ruim

Por favor, selecione o quadrado indicando sua resposta.

Pensando sobre a sua saúde, durante as últimas duas semanas, indique na sua opinião em que grau, as sentenças abaixo são verdadeiras ou não:

\begin{tabular}{|c|c|c|c|c|}
\hline & $\begin{array}{c}\text { Sempre é } \\
\text { verdade }\end{array}$ & $\begin{array}{c}\text { Quase } \\
\text { sempre é } \\
\text { verdade }\end{array}$ & $\begin{array}{l}\text { Às vezes é } \\
\text { verdade }\end{array}$ & $\begin{array}{l}\text { Nunca é } \\
\text { verdade }\end{array}$ \\
\hline \multicolumn{5}{|l|}{$\begin{array}{l}\text { 19. Eu tenho dificuldade em me recuperar } \\
\text { após esforço físico }\end{array}$} \\
\hline \multicolumn{5}{|l|}{$\begin{array}{l}\text { 20. Eu preciso limitar atividades intensas } \\
\text { como correr ou jogar }\end{array}$} \\
\hline \multicolumn{5}{|l|}{ 21. Eu tenho que me esforçar para comer } \\
\hline \multicolumn{5}{|l|}{$\begin{array}{l}\text { 22. Eu preciso ficar em casa mais do que eu } \\
\text { gostaria }\end{array}$} \\
\hline \multicolumn{5}{|l|}{$\begin{array}{l}\text { 23. Eu me sinto bem falando sobre a minha } \\
\text { doença com os outros }\end{array}$} \\
\hline \multicolumn{5}{|l|}{ 24. Eu acho que estou muito magro(a) } \\
\hline \multicolumn{5}{|l|}{$\begin{array}{l}\text { 25. Eu acho que minha aparência é } \\
\text { diferente dos outros da minha idade }\end{array}$} \\
\hline \multicolumn{5}{|l|}{$\begin{array}{l}\text { 26. Eu me sinto mal com a minha aparência } \\
\text { física }\end{array}$} \\
\hline \multicolumn{5}{|l|}{$\begin{array}{l}\text { 27. As pessoas têm medo que eu possa ser } \\
\text { contagioso(a) }\end{array}$} \\
\hline \multicolumn{5}{|l|}{ 28. Eu fico bastante com os meus amigos } \\
\hline \multicolumn{5}{|l|}{$\begin{array}{l}\text { 29. Eu penso que a minha tosse incomoda } \\
\text { os outros }\end{array}$} \\
\hline \multicolumn{5}{|l|}{ 30. Eu me sinto confortável ao sair de noite } \\
\hline \multicolumn{5}{|l|}{ 31. Eu me sinto sozinho(a) com frequência } \\
\hline 32. Eu me sinto saudável & & & & \\
\hline
\end{tabular}


33. É difícil fazer planos para o futuro (por exemplo frequentar faculdade, casar, progredir no emprego)

34. Eu levo uma vida normal

\section{SEÇÃO III. ESCOLA, TRABALHO OU ATIVIDADES DIÁRIAS}

\section{Por favor, escolha o número ou selecione o quadrado indicando sua resposta.}

35. Quantos problemas você teve para manter suas atividades escolares, trabalho profissional ou outras atividades diárias, durante as últimas duas semanas:

( ) 1. Você não teve problemas

( ) 2. Você conseguiu manter atividades, mas foi difícil

( ) 3. Você ficou para trás

( ) 4. Você não conseguiu realizar as atividades, de nenhum modo

36. Quantas vezes você faltou à escola, ao trabalho ou não conseguiu fazer suas atividades diárias por causa da sua doença ou dos seus tratamentos nas últimas duas semanas?

( ) sempre ( ) frequentemente ( ) às vezes ( ) nunca

37. O quanto a Fibrose Cística atrapalha você para cumprir seus objetivos pessoais, na escola ou no trabalho?

( ) sempre ( ) frequentemente ( ) às vezes ( ) nunca

38. O quanto a Fibrose Cística interfere nas suas saídas de casa, tais como fazer compras ou ir ao banco?

( ) sempre ( ) frequentemente ( ) às vezes ( ) nunca

\section{SEÇÃO IV. DIFICULDADES NOS SINTOMAS}

Por favor, assinale a sua resposta.

Indique como você têm se sentido durante as últimas duas semanas.

\begin{tabular}{|l|l|l|l|l|}
\hline & Muito(a) & Algum(a) & $\begin{array}{c}\text { Um } \\
\text { pouco }\end{array}$ & Nada \\
\hline \begin{tabular}{l|l|l|l|}
\hline 39. Você teve dificuldade para ganhar \\
peso?
\end{tabular} & & & & \\
\hline 40. Você estava encatarrado(a)? & & & & \\
\hline 41. Você tem tossido durante o dia? & & & & \\
\hline 42. Você teve que expectorar catarro? & & & & $*$ \\
\hline
\end{tabular}




\section{*Vá para a questão 44}

43. O seu catarro (muco) tem sido predominantemente:
( ) claro
( ) claro para amarelado
( ) amarelo - esverdeado
( ) verde com traços de sangue
( ) não sei

Com que frequência, nas últimas duas semanas:

\begin{tabular}{|c|c|c|c|c|}
\hline & Sempre & Frequentemente & Às vezes & Nunca \\
\hline 44. Você tem tido chiado? & & & & \\
\hline 45. Você tem tido falta de ar? & & & & \\
\hline $\begin{array}{l}\text { 46. Você tem acordado à noite por } \\
\text { causa da tosse? }\end{array}$ & & & & \\
\hline $\begin{array}{l}\text { 47. Você tem tido problema de } \\
\text { gases? }\end{array}$ & & & & \\
\hline 48. Você tem tido diarreia? & & & & \\
\hline 49. Você tem tido dor abdominal? & & & & \\
\hline $\begin{array}{l}\text { 50. Você tem tido problemas } \\
\text { alimentares? }\end{array}$ & & & & \\
\hline
\end{tabular}

Por favor, verifique se você respondeu todas as questões.

OBRIGADO POR SUA COOPERAÇÃO! 
ANEXO D

Pontuação da avaliação endoscópica de Lund-Kennedy

\begin{tabular}{|l|c|c|}
\hline \multirow{2}{*}{ Características } & \multicolumn{2}{|c|}{ Cavidade nasal } \\
\cline { 2 - 3 } Eólipo $(\mathbf{0}, \mathbf{1}, \mathbf{2})$ & & \multicolumn{1}{|c|}{ direita } \\
Secreção $(\mathbf{0}, \mathbf{1 , 2})$ & \\
\hline Total & \\
\hline Nota: & \\
Pólipos: 0 - ausente; 1 - restrito ao meato médio; 2 - estendendo-se à cavidade nasal \\
Edema de mucosa: 0 - ausente; 1 - discreta/moderado edema; 2 - degeneração polipoide \\
Secreção: 0 - ausente; 1 - hialina; 2 - espessa e/ou mucopurulenta
\end{tabular}


9 REFERÊNCIAS BIBLIOGRÁFICAS 


\section{REFERÊNCIAS BIBLIOGRÁFICAS}

1. Cutting GR. Cystic fibrosis genetics: from molecular understanding to clinical application. Nat Rev Genet. 2015;16(1):45-56.

2. Elborn JS. Cystic fibrosis. Lancet. 2016;388(10059):2519-31.

3. Kang SH, Dalcin Pde T, Piltcher OB, Migliavacca Rde O. Chronic rhinosinusitis and nasal polyposis in cystic fibrosis: update on diagnosis and treatment. J Bras Pneumol. 2015;41(1):65-76.

4. Aanaes K. Bacterial sinusitis can be a focus for initial lung colonisation and chronic lung infection in patients with cystic fibrosis. J Cyst Fibros. 2013;12 Suppl 2:S120.

5. Chaaban MR, Kejner A, Rowe SM, Woodworth BA. Cystic fibrosis chronic rhinosinusitis: a comprehensive review. Am J Rhinol Allergy. 2013;27(5):387-95.

6. Folkesson A, Jelsbak L, Yang L, Johansen HK, Ciofu O, Hoiby N, et al. Adaptation of Pseudomonas aeruginosa to the cystic fibrosis airway: an evolutionary perspective. Nat Rev Microbiol. 2012;10(12):841-51.

7. Stutman HR, Marks MI. Pulmonary infections in children with cystic fibrosis. Semin Respir Infect. 1987;2(3):166-76.

8. Ramsey BW. Management of pulmonary disease in patients with cystic fibrosis. N Engl J Med. 1996;335(3):179-88.

9. Silva Filho LV, Ferreira Fde A, Reis FJ, Britto MC, Levy CE, Clark O, et al. Pseudomonas aeruginosa infection in patients with cystic fibrosis: scientific evidence regarding clinical impact, diagnosis, and treatment. J Bras Pneumol. 2013;39(4):495-512.

10. Relatórios anuais REBRAFC 2016 [Available from: http://portalgbefc.org.br/relatorios-anuais-rebrafc/.

11. Paganin P, Fiscarelli EV, Tuccio V, Chiancianesi M, Bacci G, Morelli P, et al. Changes in cystic fibrosis airway microbial community associated with a severe decline in lung function. PLoS One. 2015;10(4):e0124348.

12. Schluchter MD, Konstan MW, Drumm ML, Yankaskas JR, Knowles MR. Classifying severity of cystic fibrosis lung disease using longitudinal pulmonary function data. Am J Respir Crit Care Med. 2006;174(7):780-6. 
13. Boutin S, Graeber SY, Weitnauer M, Panitz J, Stahl M, Clausznitzer D, et al. Comparison of microbiomes from different niches of upper and lower airways in children and adolescents with cystic fibrosis. PLoS One. 2015;10(1):e0116029.

14. Ciofu O, Johansen HK, Aanaes K, Wassermann T, Alhede M, Buchwald Cv, et al. P. aeruginosa in the paranasal sinuses and transplanted lungs have similar adaptive mutations as isolates from chronically infected CF lungs. Journal of Cystic Fibrosis. 2013;12(6):729-36.

15. Aanaes K, Johansen HK, Skov M, Buchvald FF, Hjuler T, Pressler T, et al. Clinical effects of sinus surgery and adjuvant therapy in cystic fibrosis patients - can chronic lung infections be postponed? Rhinology. 2013;51(3):222-30.

16. Godoy JM, Godoy AN, Ribalta G, Largo I. Bacterial pattern in chronic sinusitis and cystic fibrosis. Otolaryngol Head Neck Surg. 2011;145(4):673-6.

17. Maliniak ML, Stecenko AA, McCarty NA. A longitudinal analysis of chronic MRSA and Pseudomonas aeruginosa co-infection in cystic fibrosis: A single-center study. J Cyst Fibros. 2016;15(3):350-6.

18. Rogers GB, Shaw D, Marsh RL, Carroll MP, Serisier DJ, Bruce KD. Respiratory microbiota: addressing clinical questions, informing clinical practice. Thorax. 2015;70(1):74-81.

19. Burns JL, Rolain JM. Culture-based diagnostic microbiology in cystic fibrosis: can we simplify the complexity? J Cyst Fibros. 2014;13(1):1-9.

20. Peterson J, Garges S, Giovanni M, McInnes P, Wang L, Schloss JA, et al. The NIH Human Microbiome Project. Genome Res. 2009;19(12):2317-23.

21. Lee JT, Frank DN, Ramakrishnan V. Microbiome of the paranasal sinuses: Update and literature review. Am J Rhinol Allergy. 2016;30(1):3-16.

22. Hauser LJ, Feazel LM, Ir D, Fang R, Wagner BD, Robertson CE, et al. Sinus culture poorly predicts resident microbiota. Int Forum Allergy Rhinol. 2015;5(1):3-9.

23. Hamady M, Knight R. Microbial community profiling for human microbiome projects: Tools, techniques, and challenges. Genome Res. 2009;19(7):1141-52.

24. Lynch SV, Bruce KD. The cystic fibrosis airway microbiome. Cold Spring Harb Perspect Med. 2013;3(3):a009738.

25. Vickery TW, Kofonow JM, Ramakrishnan VR. Characterization of Sinus Microbiota by 16S Sequencing from Swabs. Methods Mol Biol. 2017;1616:23-38. 
26. Caporaso JG, Lauber CL, Costello EK, Berg-Lyons D, Gonzalez A, Stombaugh J, et al. Moving pictures of the human microbiome. Genome Biol. 2011;12(5):R50.

27. Caporaso JG, Lauber CL, Walters WA, Berg-Lyons D, Lozupone CA, Turnbaugh PJ, et al. Global patterns of $16 \mathrm{~S}$ rRNA diversity at a depth of millions of sequences per sample. Proc Natl Acad Sci U S A. 2011;108 Suppl 1:4516-22.

28. Mahdavinia M, Keshavarzian A, Tobin MC, Landay AL, Schleimer RP. A comprehensive review of the nasal microbiome in chronic rhinosinusitis (CRS). Clin Exp Allergy. 2016;46(1):21-41.

29. Wilson MT, Hamilos DL. The nasal and sinus microbiome in health and disease. Curr Allergy Asthma Rep. 2014;14(12):485.

30. Fokkens WJ, Lund VJ, Mullol J, Bachert C, Alobid I, Baroody F, et al. EPOS 2012: European position paper on rhinosinusitis and nasal polyps 2012. A summary for otorhinolaryngologists. Rhinology. 2012;50(1):1-12.

31. Bassiouni A, Cleland EJ, Psaltis AJ, Vreugde S, Wormald PJ. Sinonasal microbiome sampling: a comparison of techniques. PLoS One. 2015;10(4):e0123216.

32. Lemon KP, Klepac-Ceraj V, Schiffer HK, Brodie EL, Lynch SV, Kolter R. Comparative analyses of the bacterial microbiota of the human nostril and oropharynx. MBio. 2010;1(3).

33. Ramakrishnan VR, Feazel LM, Gitomer SA, Ir D, Robertson CE, Frank DN. The microbiome of the middle meatus in healthy adults. PLoS One. 2013;8(12):e85507.

34. Bassis CM, Tang AL, Young VB, Pynnonen MA. The nasal cavity microbiota of healthy adults. Microbiome. 2014;2:27.

35. Abreu NA, Nagalingam NA, Song Y, Roediger FC, Pletcher SD, Goldberg AN, et al. Sinus microbiome diversity depletion and Corynebacterium tuberculostearicum enrichment mediates rhinosinusitis. Sci Transl Med. 2012;4(151):151ra24.

36. Araujo E, Dall C, Cantarelli V, Pereira A, Mariante AR. Microbiology of middle meatus in chronic rhinosinusitis. Braz J Otorhinolaryngol. 2007;73(4):549-55.

37. Ivanchenko OA, Karpishchenko SA, Kozlov RS, Krechikova OI, Otvagin IV, Sopko ON, et al. The microbiome of the maxillary sinus and middle nasal meatus in chronic rhinosinusitis. Rhinology. 2016;54(1):68-74. 
38. Boase S, Foreman A, Cleland E, Tan L, Melton-Kreft R, Pant H, et al. The microbiome of chronic rhinosinusitis: culture, molecular diagnostics and biofilm detection. BMC Infect Dis. 2013;13:210.

39. Wagner Mackenzie B, Waite DW, Hoggard M, Taylor MW, Biswas K, Douglas RG. Moving beyond descriptions of diversity: clinical and research implications of bacterial imbalance in chronic rhinosinusitis. Rhinology. 2017;55(4):291-7.

40. Cox MJ, Allgaier M, Taylor B, Baek MS, Huang YJ, Daly RA, et al. Airway microbiota and pathogen abundance in age-stratified cystic fibrosis patients. PLoS One. 2010;5(6):e11044.

41. Goddard AF, Staudinger BJ, Dowd SE, Joshi-Datar A, Wolcott RD, Aitken ML, et al. Direct sampling of cystic fibrosis lungs indicates that DNA-based analyses of upper-airway specimens can misrepresent lung microbiota. Proc Natl Acad Sci U S A. 2012;109(34):13769-74.

42. Fodor AA, Klem ER, Gilpin DF, Elborn JS, Boucher RC, Tunney MM, et al. The adult cystic fibrosis airway microbiota is stable over time and infection type, and highly resilient to antibiotic treatment of exacerbations. PLoS One. 2012;7(9):e45001.

43. Coburn B, Wang PW, Diaz Caballero J, Clark ST, Brahma V, Donaldson S, et al. Lung microbiota across age and disease stage in cystic fibrosis. Sci Rep. 2015;5:10241.

44. Mika M, Korten I, Qi W, Regamey N, Frey U, Casaulta C, et al. The nasal microbiota in infants with cystic fibrosis in the first year of life: a prospective cohort study. Lancet Respir Med. 2016;4(8):627-35.

45. Hoggard M, Biswas K, Zoing M, Wagner Mackenzie B, Taylor MW, Douglas RG. Evidence of microbiota dysbiosis in chronic rhinosinusitis. Int Forum Allergy Rhinol. 2017;7(3):230-9.

46. Hansen SK, Rau MH, Johansen HK, Ciofu O, Jelsbak L, Yang L, et al. Evolution and diversification of Pseudomonas aeruginosa in the paranasal sinuses of cystic fibrosis children have implications for chronic lung infection. Isme j. 2012;6(1):3145.

47. Johansen HK, Aanaes K, Pressler T, Nielsen KG, Fisker J, Skov M, et al. Colonisation and infection of the paranasal sinuses in cystic fibrosis patients is accompanied by a reduced PMN response. J Cyst Fibros. 2012;11(6):525-31. 
48. Bezerra TF, Piccirillo JF, Fornazieri MA, de MPRR, Abdo TR, de Rezende Pinna F, et al. Cross-Cultural Adaptation and Validation of SNOT-20 in Portuguese. Int J Otolaryngol. 2011;2011:306529.

49. Bezerra TF, Padua FG, Pilan RR, Stewart MG, Voegels RL. Cross-cultural adaptation and validation of a quality of life questionnaire: the Nasal Obstruction Symptom Evaluation questionnaire. Rhinology. 2011;49(2):227-31.

50. Rozov T, Cunha MT, Nascimento O, Quittner AL, Jardim JR. Linguistic validation of cystic fibrosis quality of life questionnaires. J Pediatr (Rio J). 2006;82(2):151-6.

51. Lund VJ, Kennedy DW. Staging for rhinosinusitis. Otolaryngol Head Neck Surg. 1997;117(3 Pt 2):S35-40.

52. Hammerschlag MR, Harding L, Macone A, Smith AL, Goldmann DA. Bacteriology of sputum in cystic fibrosis: evaluation of dithiothreitol as a mucolytic agent. J Clin Microbiol. 1980;11(6):552-7.

53. Sinha R, Weissenburger-Moser LA, Clarke JL, Smith LM, Heires AJ, Romberger DJ, et al. Short term dynamics of the sputum microbiome among COPD patients. PLoS One. 2018;13(3):e0191499.

54. Klindworth A, Pruesse E, Schweer T, Peplies J, Quast C, Horn M, et al. Evaluation of general 16S ribosomal RNA gene PCR primers for classical and next-generation sequencing-based diversity studies. Nucleic Acids Res. 2013;41(1):e1.

55. Gosiewski T, Jurkiewicz-Badacz D, Sroka A, Brzychczy-Wloch M, Bulanda M. A novel, nested, multiplex, real-time PCR for detection of bacteria and fungi in blood. BMC Microbiol. 2014;14:144.

56. Caporaso JG, Kuczynski J, Stombaugh J, Bittinger K, Bushman FD, Costello EK, et al. QIIME allows analysis of high-throughput community sequencing data. Nat Methods. 7. United States2010. p. 335-6.

57. Jovel J, Patterson J, Wang W, Hotte N, O'Keefe S, Mitchel T, et al. Characterization of the Gut Microbiome Using 16S or Shotgun Metagenomics. Front Microbiol. 2016;7:459.

58. Quast C, Pruesse E, Yilmaz P, Gerken J, Schweer T, Yarza P, et al. The SILVA ribosomal RNA gene database project: improved data processing and web-based tools. Nucleic Acids Res. 2013;41(Database issue):D590-6.

59. Shannon CE. The mathematical theory of communication. 1963. MD Comput. 1997;14(4):306-17. 
60. Pylro VS, Roesch LF, Morais DK, Clark IM, Hirsch PR, Totola MR. Data analysis for $16 \mathrm{~S}$ microbial profiling from different benchtop sequencing platforms. J Microbiol Methods. 2014;107:30-7.

61. Lozupone C, Knight R. UniFrac: a new phylogenetic method for comparing microbial communities. Appl Environ Microbiol. 2005;71(12):8228-35.

62. Lozupone CA, Hamady M, Kelley ST, Knight R. Quantitative and qualitative beta diversity measures lead to different insights into factors that structure microbial communities. Appl Environ Microbiol. 2007;73(5):1576-85.

63. Dhariwal A, Chong J, Habib S, King IL, Agellon LB, Xia J. MicrobiomeAnalyst: a web-based tool for comprehensive statistical, visual and meta-analysis of microbiome data. Nucleic Acids Res. 2017;45(W1):W180-w8.

64. Navas-Molina JA, Peralta-Sanchez JM, Gonzalez A, McMurdie PJ, Vazquez-Baeza $\mathrm{Y}, \mathrm{Xu} \mathrm{Z}$, et al. Advancing our understanding of the human microbiome using QIIME. Methods Enzymol. 2013;531:371-444.

65. Zemanick ET, Harris JK, Wagner BD, Robertson CE, Sagel SD, Stevens MJ, et al. Inflammation and airway microbiota during cystic fibrosis pulmonary exacerbations. PLoS One. 2013;8(4):e62917. 
APÊNDICES 


\section{APÊNDICE 1 \\ Aprovação pelo Comitê de Ética}

Hospital das Clínicas da FMUSP

Comissão de Ética para Análise de Projetos de Pesquisa - CAPPesq

\section{PROJETO DE PESQUISA}

Título: AVALIAÇÃO DO MICROBIOMA NASOSSINUSAL DE PACIENTES COM FIBROSE CÍSTICA Pesquisador Responsável: Prof. Dr. Richard Louis Voegels Versão: 2 Pesquisador Executante: Flávia Gonçalves de Oliveira CAAE: 49049015.6 .0000 .0068

Maestrali

Co-autores: Renata de Mendonça Pilan

Finalidade Acadêmica Doutorado

Orientador: Prof. Dr Richard Louis Voegels

Instituição: HCFMUSP

Departamento: OFTALMOLOGIA E OTORRINOLARINGOLOGIA

\section{PARECER CONSUBSTANCIADO DO CEP}

Registro on-line: 14045

Número do Parecer: 1.453 .561

Data da Relatoria: $16 / 03 / 2016$

Apresentação do Projeto: Projeto avalia o microbioma dos seios paranasais de pacientes adultos com Fibrose Cistica.

Objetivo da Pesquisa: 0 objetivo principal do presente estudo é descrever o microbioma nasossinusal de pacientes adultos com fibrose cistica. Os objetivos secundários são comparar o microbioma nasossinusal com o microbioma do escarro desses pacientes, estabelecer relação entre o microbioma e função pulmonar, grau de acometimento nasossinusal e qualidade de vida.

Avaliação dos Riscos e Benefícios: Já descritos em parecer anterior.

Comentários e Consideraçães sobre a Pesquisa: A pesquisa é muito interessante e exequivel. Os pesquisadores descrevem adequadamente os passos a serem seguidos. Os autores realizaram ainda outras modificações no projeto principal.

Considerações sobre os Termos de apresentação obrigatória: Os pesquisadores reescrevem o Termo de Consentimento Livre e Esclarecido de acordo com as exigências desta comissão. Conclusões ou Pendências e Lista de Inadequações: Sem pendências.

Situação do Parecer: Aprovado.

Necessita Apreciação da CONEP: Não.

Considerações Finais a critério do CEP: Em conformidade com a Resolução CNS n 466/12 cabe ao pesquisador: a) desenvolver o projeto conforme delineado; b) elaborar e apresentar relatórios parciais e final; c)apresentar dados solicitados pelo CEP, a qualquer momento; d) manter em arquivo sob sua guarda, por $\mathbf{5}$ anos da pesquisa, contendo fichas individuais e todos os demais documentos recomendados pelo CEP; e) encaminhar os resultados para publicação, com os devidos créditos aos pesquisadores associados e ao pessoal técnico participante do projeto; f) justificar perante ao CEP interrupção do projeto ou a não publicação dos resultados.

São Paulo, 16 de Março de 2016

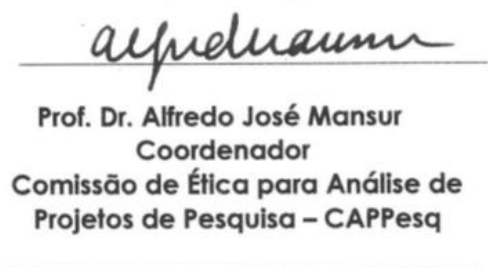

Rua Dr. Ovídio Pires de Campos, 225 - Prédio da Administração - 5ªndar CEP 05403-010 - São Paulo - SP.

5511 2661-7585 | cappesq.adm@hc.fm.usp.br 


\section{APÊNDICE 2}

\section{Termo de Consentimento Livre e Esclarecido}

\section{HOSPITAL DAS CLÍNICAS DA FACULDADE DE MEDICINA DA UNIVERSIDADE DE SÃO PAULO-HCFMUSP TERMO DE CONSENTIMENTO LIVRE E ESCLARECIDO}

\section{DADOS DA PESQUISA}

Título da pesquisa - Avaliação do microbioma nasossinusal de pacientes com Fibrose Cística

Pesquisador principal - Richard Louis Voegels

Departamento/Instituto - Oftalmologia e Otorrinolaringologia, Disciplina de Otorrinolaringologia

Convidamos o(a) Sr(a) para participar desta pesquisa que tem como objetivo avaliar de forma detalhada as bactérias presentes no nariz e no escarro de pacientes com fibrose cística. Sua participação é voluntária.

Você irá responder a questionários com perguntas que detalham um pouco mais a história e o desconforto da sua doença. Não será feita qualquer pergunta sobre sua intimidade e você poderá negar-se a responder a qualquer momento alguma questão que não se sinta a vontade para responder, bem como interromper o questionário.

Você fará uma nasofibroscopia que servirá para vermos através da televisão, como numa endoscopia, como está a doença dentro do seu nariz e os locais onde têm inflamação e catarro. $\mathrm{O}$ exame pode ser feito com anestesia local e o desconforto será mínimo. $\mathrm{O}$ aparelho não fura e não corta, mas em algumas pessoas pode causar sangramento por causa da sua passagem em uma pele muito inflamada dentro do seu nariz.

Será coletada amostra de escarro e uma amostra de secreção na entrada dos seios da face, com um cotonete bem fino e delicado. Esse procedimento dura apenas alguns segundos e será realizado durante a nasofibroscopia. Ele pode causar desconforto mínimo. Alguns pacientes podem apresentar vontade de espirrar e coçar o nariz durante o procedimento.

Você será submetido a tomografia computadorizada de seios paranasais, caso não tenha realizado esse exame nos últimos 3 meses. A tomografia é um exame simples e comum, que lembra um RX e apenas demora um pouco mais. Ela servirá para avaliar se algum local do seu nariz foi afetado pela fibrose cística. Não será preciso usar contraste e os riscos são muito pequenos, mas se você estiver grávida não poderá fazê-lo.

Os resultados desse trabalho podem trazer benefícios diretos para o participante, pois saberemos as bactérias presentes nos seios da face e poderemos direcionar um tratamento específico se for necessário, mas também serão importantes para melhorar o 
conhecimento científico a respeito da sua doença trazendo benefício a outras pessoas com fibrose cística;

Você pode se recusar a participar ou pode retirar o seu consentimento em qualquer fase da pesquisa sem penalização alguma, sem qualquer prejuízo à continuidade de seu tratamento na Instituição.

As informações obtidas serão analisadas em conjunto com outros pacientes, não sendo divulgado a identificação de nenhum paciente;

Você receberá uma via desse termo de consentimento.

As bactérias da secreção nasal e do escarro obtidos para esta pesquisa poderão ser armazenados de acordo com a resolução 441/2011, para possíveis estudos futuros. Toda nova pesquisa só será realizada com sua autorização bem como com aprovação do sistema CEPCONEP.

Em qualquer etapa do estudo, você terá acesso aos profissionais responsáveis pela pesquisa para esclarecimento de dúvidas. O principal investigador é a Dr Richard Louis Voegels, que pode ser encontrado no endereço 6o.andar/sala 6 do Prédio dos Ambulatórios do Hospital das Clínicas (PAMB) da FMUSP situado na Av Dr. Enéas de Carvalho Aguiar, 255, Cerqueira César, São Paulo - SP. Telefone(s) 2661-6539. Se você tiver alguma consideração ou dúvida sobre a ética da pesquisa, entre em contato com o Comitê de Ética em Pesquisa (CEP) - Rua Ovídio Pires de Campos, 225 - $5^{\circ}$ andar - tel: 2661-6442 ramais 16, 17, 18 - e-mail: cappesq.adm@hc.fm.usp.br

Fui suficientemente informado a respeito do estudo "Avaliação do microbioma nasossinusal de pacientes com Fibrose Cística".

Eu discuti as informações acima com o Pesquisador Responsável Dr. Richard Voegels ou pessoa(s) por ele delegada(s) (..............................................) sobre a minha decisão em participar nesse estudo. Ficaram claros para mim os objetivos, os procedimentos, os potenciais desconfortos e riscos e as garantias. Concordo voluntariamente em participar deste estudo, assino este termo de consentimento e recebo uma via rubricada pelo pesquisador.

Assinatura do participante /representante legal

Data / /

Assinatura do responsável pelo estudo

Data / / 
DADOS DE IDENTIFICAÇÃO (OU ETIQUETA INSTITUCIONAL DE IDENTIFICAÇÃO) DO PARTICIPANTE DA PESQUISA OU RESPONSÁVEL LEGAL

1. NOME:

DOCUMENTO DE IDENTIDADE ${ }^{\circ}$ : SEXO: .M $\square \mathrm{F} \square$

DATA NASCIMENTO: .1

ENDEREÇO $\mathrm{N}^{\circ}$ APTO:

BAIRRO: CIDADE:

CEP: TELEFONE: DDD (.....).

2.RESPONSÁVEL LEGAL

NATUREZA (grau de parentesco, tutor, curador etc.)

DOCUMENTO DE IDENTIDADE ${ }^{\circ}$ : SEXO: .M $\square \mathrm{F}$

DATA NASCIMENTO: .1

ENDEREÇO $\mathrm{N}^{\circ}$ APTO:

BAIRRO: CIDADE:

CEP: TELEFONE: DDD (....... 